UNIVERSIDADE DE SÃO PAULO

ESCOLA DE ENGENHARIA DE LORENA

ISABEL ROCHA DO MONTE

CARACTERIZAÇÃO MICROESTRUTURAL DO AÇO API 5L X65 SOLDADO POR FEIXE DE ELÉTRONS COM DIFERENTES APORTES TÉRMICOS

LORENA 

ISABEL ROCHA DO MONTE

\section{CARACTERIZAÇÃO MICROESTRUTURAL DO AÇO API 5L X65 SOLDADO POR FEIXE DE ELÉTRONS COM DIFERENTES APORTES TÉRMICOS}

Dissertação de Mestrado apresentada à Escola de Engenharia de Lorena da Universidade de São Paulo para a obtenção do título de Mestre em Ciências do Programa de Pós-graduação em Engenharia de Materiais na área de concentração: Materiais metálicos, cerâmicos e poliméricos.

Orientador: Prof. Dr. Hugo R.Z. Sandim.

Edição reimpressa e corrigida

LORENA

Julho-2013 


\begin{abstract}
AUTORIZO A REPRODUÇÃO E DIVULGAÇÃO TOTAL OU PARCIAL DESTE TRABALHO, POR QUALQUER MEIO CONVENCIONAL OU ELETRÔNICO, PARA FINS DE ESTUDO E PESQUISA, DESDE QUE CITADA A FONTE.
\end{abstract}

Catalogação na Publicação

Elaborada pela Biblioteca Especializada em Engenharia de Materiais Escola de Engenharia de Lorena da Universidade de São Paulo

Monte, Isabel Rocha do

Caracterização microestrutural do aço API 5L X65 soldado por feixe de elétrons com diferentes aportes térmicos / Isabel Rocha do Monte.-ed. Reimp.—corr.-- 2013.

90 p.: il.

Dissertação (Mestre em Ciências - Programa de Pós Graduação em Engenharia de Materiais. Área de Concentração: Materiais Metálicos, Cerâmicos e Poliméricos) - Escola de Engenharia de Lorena - Universidade de São Paulo, 2013.

Orientador: Hugo Ricardo Zschommler Sandim

1. Constituintes microestruturais 2. Soldagem por feixe de elétrons 3. Aço API 5L X65 I. Título. 
Dedico este trabalho a minha família pelo amor, gratidão, compreensão, apoio e pela presença em todos os dias de minha vida. 



\section{AGRADECIMENTOS}

Agradeço primeiramente à minha família que sempre esteve presente em minha vida, apoiando, fortalecendo e acreditando que posso alcançar meus objetivos.

Agradeço aos colegas do PPGEM, pela paciência, experiências trocadas, ensinamentos e amizade, especialmente aos amigos Reny Renzetti, Giseli Ribeiro, Rodrigo Siqueira e Bento Ferreira.

Agradeço ao orientador e professor Dr. Hugo Ricardo Zschommler Sandim por acreditar neste projeto e compartilhar a realização deste de maneira clara e objetiva.

Agradeço ao professor Dr. Miguel Justino Barboza pela amizade, compreensão, paciência e por estar ao meu lado no auxílio de informações e decisões.

Agradeço aos professores, técnicos e funcionários do Departamento de Engenharia de Materiais da Escola de Engenharia de Lorena EEL-USP e do Programa de Pós - Graduação em Engenharia de Materiais - PPGEM que contribuíram e auxiliaram no meu desenvolvimento e formação.

Agradeço à empresa INB - Indústrias Nucleares do Brasil S.A. pela realização da soldagem nos corpos-de-prova para o desenvolvimento do projeto.

Agradeço à Usiminas (ex-Cosipa) pelo fornecimento do aço utilizado nesta Dissertação.

Agradeço aos técnicos do laboratório da empresa Confab Industrial S.A. que me apoiaram na fase final do projeto. 



\section{RESUMO}

MONTE, I. R. Caracterização microestrutural do aço API 5L X65 soldado por feixe de elétrons com diferentes aportes térmicos. 2013. 90 p. Dissertação (Mestrado em Ciências) - Escola de Engenharia de Lorena, Universidade de São Paulo, Lorena, 2013.

Esta Dissertação abrange a caracterização microestrutural do aço API 5L X65 soldado por feixe de elétrons (EBW) com cinco diferentes aportes térmicos e sem o uso de metal de adição. O aço API 5L X65 pertence à classe de aços ARBL e é empregado na fabricação de oleodutos e gasodutos. As três regiões da solda metal-base (MB), zona termicamente afetada (ZTA) e zona fundida (ZF) foram caracterizadas por microscopia ótica (MO), microscopia eletrônica de varredura (MEV), difração de raios X e medidas de microdureza Vickers. As microestruturas encontradas nestas três regiões são bastante distintas. O MB apresenta grãos ferríticos com bandas perlíticas orientadas paralelamente à direção de laminação. Devido à elevada densidade de potência do processo EBW e às elevadas velocidades de soldagem utilizadas, a ZTA é bastante estreita sendo formada por grãos ferríticos finos e bandas perlíticas degeneradas que a diferem do MB. Na interface ZTA/ZF foi possível observar a presença de grãos com morfologia acicular com a presença dos constituintes M-A (martensita-austenita). A ZF apresentou morfologia similar à encontrada em aços microligados soldados: ferrita alotriomórfica, ferrita acicular, ferrita de Widmanstätten, constituintes M-A, além de regiões bainíticas. Na parte central da chapa foi observada a segregação de manganês. A técnica EBW permite a soldagem de tubos com paredes espessas com apenas um passe. Os resultados desta Dissertação são úteis para avaliar a viabilidade técnica do uso de EBW na fabricação de tubos para o transporte de óleo e gás, especialmente em aços mais resistentes (bainíticos).

Palavras-chave: Constituintes microestruturais, Soldagem por feixe de elétrons, Aço API 5L X65. 


\begin{abstract}
MONTE, I. R. Microstructural characterization of API 5L X65 steel welded by electron-beam with different heat inputs. 2013.90 p. Dissertation (Master of Science) Escola de Engenharia de Lorena, Universidade de São Paulo, Lorena, 2013.

This Dissertation aims at the microstructural characterization of electron-beam welded (EBW) API 5L X65 steel using five different processing conditions (heat input) and without filler metal addition. The API 5L X65 steel is a high-strength low-alloy (HSLA) steel employed mainly in the manufacture of pipelines for oil and gas. The three regions of the welds, namely the base metal (BM), heat affected zone (HAZ) and fusion zone (FZ) were characterized by light optical microscopy using different chemical etching agents, scanning electron microscopy, X-ray diffraction and Vickers microhardness testing. The microstructures found in the three regions were quite distinct. The BM consists of elongated ferritic grains with pearlite bands oriented along the rolling direction. Due to the high power density provided by EBW, the HAZ is very narrow and consists of ferritic grains and bands of degenerated pearlite. At the HAZ/FZ interface it is possible to observe the presence of grains with acicular morphology and the presence of M-A (martensiteretained austenite) constituents. The FZ showed a morphology similar to that one found in molten microalloyed steels consisting of allotriomorphic ferrite, acicular ferrite, Widmanstätten-like ferrite, M-A constituents, as well as bainite. In the central part of the plate it was observed the presence of Mn-segregation lines along the BM. The electron beam welding was chosen because it produces a relatively small HAZ and it allows the welding of thick-wall tubes in one single pass. The results of this work are useful to evaluate the possibility of using EBW in the manufacture of pipelines for transport of oil and gas, especially in higher grade steels.
\end{abstract}

Keywords: Microstructural constituents, Electron beam welding, API 5L X65 steel. 


\section{LISTA DE FIGURAS}

Figura 1. Desenvolvimento dos aços microligados tipo API (HILLENBRAND, 2002)..... 21 Figura 2. Processo de laminação controlada com e sem o resfriamento acelerado (Adaptado de Hillenbrand, 2001).

Figura 3. Influência da adição de microligantes na temperatura de recristalização de austenita (CUDDY, 1982)

Figura 4. Potência específica em função do processo de soldagem (Adaptado de Rykaline, 1974).

Figura 5. Diagrama TRC para um aço microligado. BF: Ferrita Bainitica; AF: Ferrita Acicular; PF: Ferrita Poligonal e P: Perlita (ZHAO, 2003).

Figura 6. Curva CCT do aço em estudo API 5L X65, construída pela Usiminas ( $\mathrm{F}=$ ferrita, $\mathrm{P}=$ perlita, $\mathrm{B}=$ bainita e $\mathrm{M}=$ martensita). Os números indicam as frações volumétricas de cada constituinte. 36

Figura 7. (a) Esquema dos constituintes essenciais da microestrutura nos grãos austeníticos colunares do aço soldado. (b) Microestrutura via MEV de um aço soldado (cortesia de Rees). Os termos $\alpha, \alpha w$, e $\alpha$ a referem-se à ferrita alotriomórfica, ferrita de Widmanstätten e ferrita acicular, respectivamente (BHADESHIA, 2006)

Figura 8. Ilustração esquemática da variação microestrutural esperada na ZTA de um aço carbono soldado (BHADESHIA, 2006).

Figura 9. Microestruturas das diferentes regiões da ZTA. (a) região revenida; (b) região parcialmente transformada e (c) região completamente austenitizada (BHADESHIA, 2006).

Figura 10. Peça soldada com dimensão, velocidade dos cordões de solda e sentido de laminação perpendicular à soldagem.

Figura 11 - Máquina de solda por feixe de elétrons instalada na INB. (SÁ, 2005). 45

Figura 12 - Câmara de soldagem por feixe de elétrons e detalhe da mesa X-Y-Z (SÁ, 2005).

Figura 13. Representação esquemática das medidas de microdureza Vickers ao longo das amostras. 48

Figura 14. Curva dilatométrica do aço API 5L X65 para uma taxa de aquecimento de $1^{\circ} \mathrm{C} / \mathrm{s}$ 
Figura 15. Curva dilatométrica do aço API 5L X65 para uma taxa de aquecimento de $5^{\circ} \mathrm{C} / \mathrm{s}$ 50

Figura 16. Curva dilatométrica do aço API 5L X65 para uma taxa de aquecimento de $30^{\circ} \mathrm{C} / \mathrm{s}$. 50

Figura 17. Grade de pontos ilustrativa para quantificação de fases da seção transversal do aço API 5L X 65.

Figura 18. Micrografias via microscopia óptica e microscopia eletrônica de varredura apresentando linha de segregação central na seção transversal da chapa. 53 Figura 19. Microestruturas via microscopia óptica da junta soldada com velocidade de 2 mm/s. (a) MB; (b) ZTA e interface ZTA/ZF; (c) ZF e (d) ZF, destaque para a possível microestrutura bainita. Ataque: Nital $2 \%$. 54 Figura 20. Microestruturas via microscopia óptica da junta soldada com velocidade de 6 mm/s. (a) MB; (b) interface MB / ZTA e ZTA e (c) ZF. Ataque: Nital $2 \%$. 55 Figura 21. Microestruturas via microscopia óptica da junta soldada com velocidade de 10 mm/s (a) MB; (b) interface MB / ZTA e ZTA e (c) ZF. Ataque: Nital 2\%. 56 Figura 22. Microestruturas via microscopia óptica da junta soldada com velocidade de 14 mm/s. (a) MB; (b) ZTA e (c) ZF. Aumento: 500x. Ataque: Nital 2\%. 57 Figura 23. Microestruturas obtidas por microscopia óptica da junta soldada com velocidade de 18 mm/s. (a) MB; (b) ZTA e (c) ZF. Aumento: 500x. Ataque: Nital 2\% ....58 Figura 24. (a) Presença dos constituintes M-A na linha de segregação central do MB, indicadas pelas setas; (b) Presença dos constituintes M-A dispersos na ZTA. Aumento: 1000x. Coloração - azulada e marrom: ferrita, branca: constituinte M-A.

Figura 25. Detalhe da região central da chapa. MO com ampliação de 1000x. (OGATA, 2009)

Figura 26. Presença de bainita na amostra de $18 \mathrm{~mm} / \mathrm{s}$. (a) Destaque para o início formação da bainita; (b) Destaque para a bainita formada próxima ao contorno de grão austenítico.

Figura 27. Largura da ZTA para as cinco condições de aporte térmico. 64 Figura 28. Microestrutura do aço API-5L X65 evidenciando aspectos morfológicos da: (a) perlita lamelar no MB; (b) perlita degenerada na ZTA (elétrons secundários). 65 Figura 29. Microestrutura do aço API-5L X65 na ZF evidenciando a presença dos constituintes: (a) bainita superior (elétrons retroespalhados); (b) bainita inferior (elétrons secundários) 66

Figura 30. Perfil de microdureza Vickers da junta soldada com velocidade de $2 \mathrm{~mm} / \mathrm{s}$..... 68 
Figura 31. Perfil de microdureza Vickers da junta soldada com velocidade de $6 \mathrm{~mm} / \mathrm{s}$.... 70 Figura 32. Perfil de microdureza Vickers da junta soldada com velocidade de $10 \mathrm{~mm} / \mathrm{s}$... 71 Figura 33. Perfil de microdureza Vickers da junta soldada com velocidade de $14 \mathrm{~mm} / \mathrm{s}$.. 72 Figura 34. Perfil de microdureza Vickers da junta soldada com velocidade de $18 \mathrm{~mm} / \mathrm{s}$... 73 Figura 35. Comparação das diferentes regiões de medição de microdureza Vickers (topo, centro e raiz) das cinco amostras em estudo. 75 Figura 36. Difratogramas de raios $\mathrm{X}$ na $\mathrm{ZF}$ das amostras soldadas com velocidades de $6 \mathrm{~mm} / \mathrm{s}$ e $14 \mathrm{~mm} / \mathrm{s}$. 77 


\section{LISTA DE TABELAS}

Tabela 1. Composição química do aço API X65 (fornecida pela USIMINAS). 44

Tabela 2. Propriedades mecânicas do aço API 5L X65 obtidas por ensaios de tração ( USIMINAS)

Tabela 3. Propriedades mecânicas do aço API 5L X65 obtidas por ensaios Charpy (USIMINAS) .44

Tabela 4. Condições de ensaio de dilatometria do aço como recebido. ..................................46

Tabela 5. Fração volumétrica de ferrita e perlita no MB

Tabela 6. Relação penetração versus largura dos cordões de solda das cinco amostras em estudo. .52

Tabela 7. Comparação da microdureza Vickers das cinco amostras em estudo .74

Tabela 8. Taxa de resfriamento calculada para as cinco velocidades de soldagem................78

Tabela 9. Taxas de resfriamento típicas para uma barra de aço em diferentes meios. 


\section{SUMÁRIO}

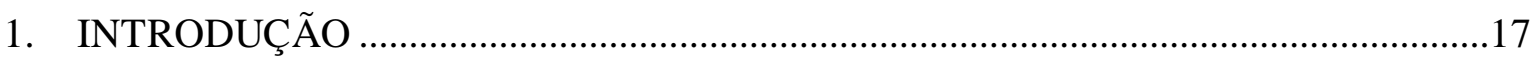

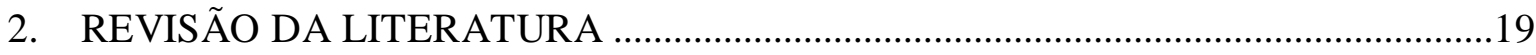

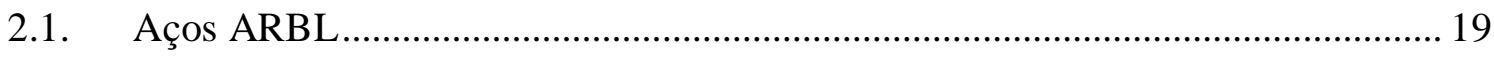

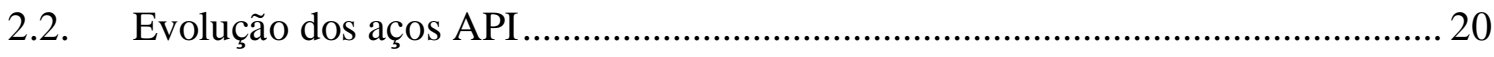

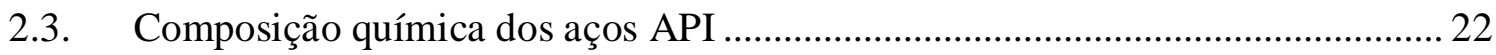

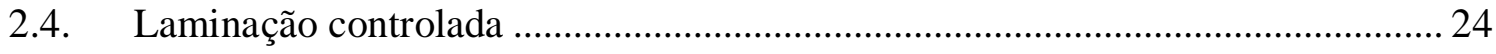

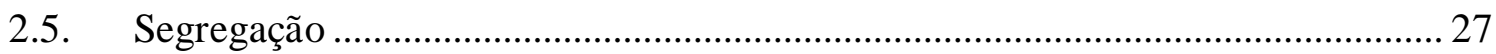

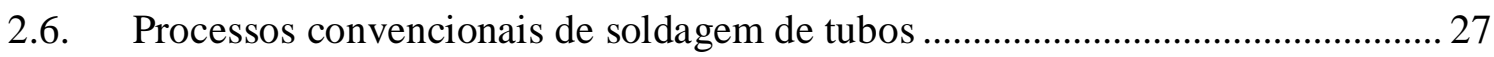

2.6.1. Soldagem por arco submerso (SAW - Submerged Arc Welding) ................... 28

2.6.2. Soldagem por resistência elétrica (ERW - Electric Resistence Welding) ......... 28

2.7. soldagem por feixe de elétrons (EBW - Electron Beam Welding) ........................ 29

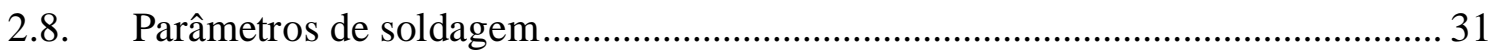

2.9. Transferência de calor no processo de soldagem ................................................... 32

2.10. Efeitos térmicos no cordão de solda ......................................................................... 33

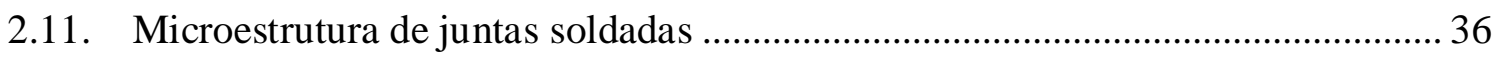

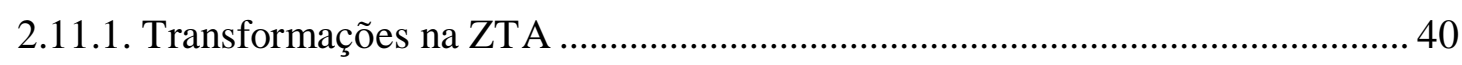

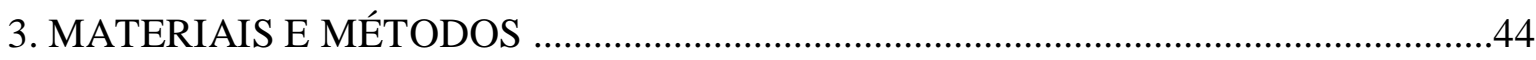

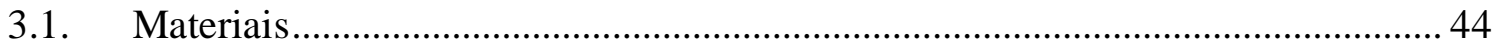

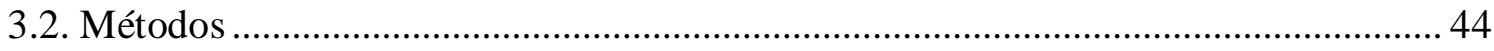

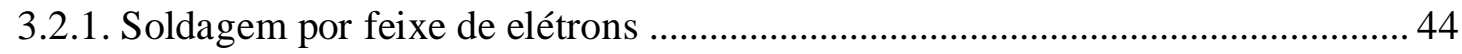

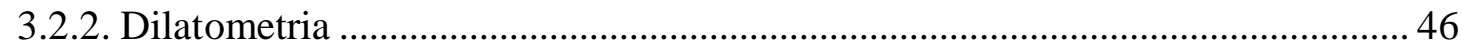

3.2.3. Preparação metalográfica das amostras .............................................................. 47

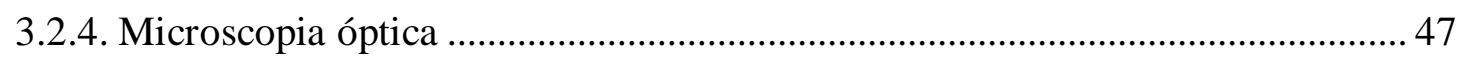

3.2.5. Microscopia eletrônica de varredura (MEV) ….................................................. 47

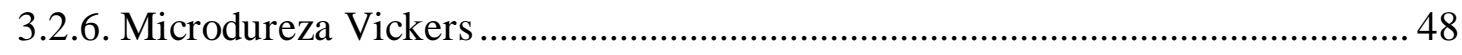

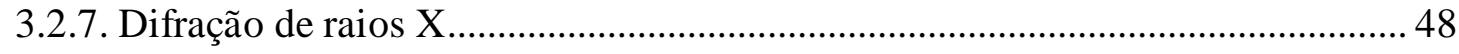

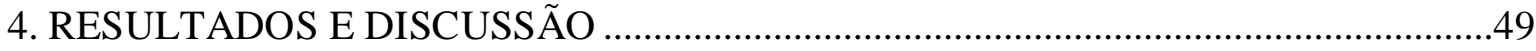

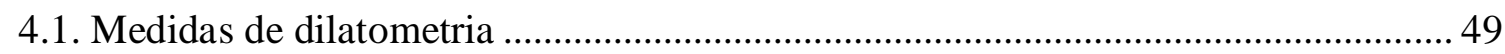

4.2. Fração volumétrica das fases e dos constituintes microestruturais no Metal-Base .. 51

4.3. Profunidade versus largura das amostras ................................................................ 52

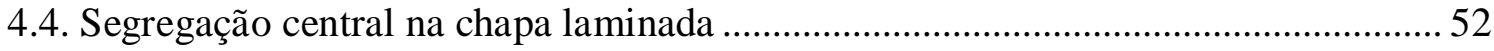

4.5. Caracterização microestrutural da região soldada ..................................................... 53 


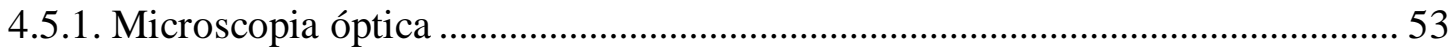

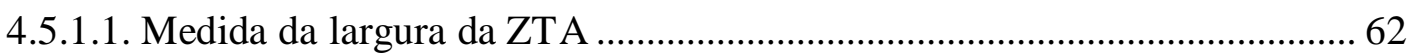

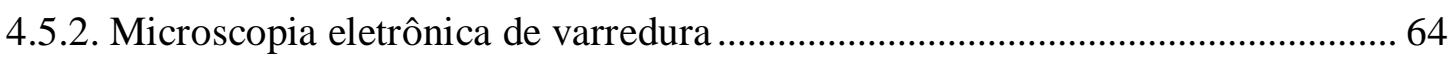

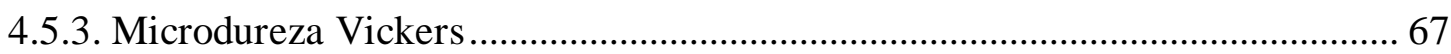

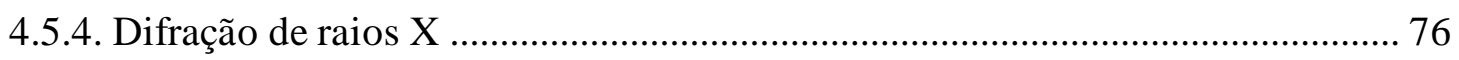

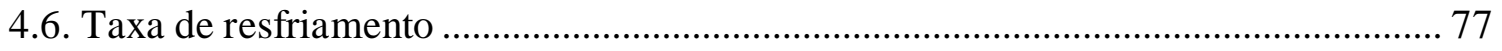

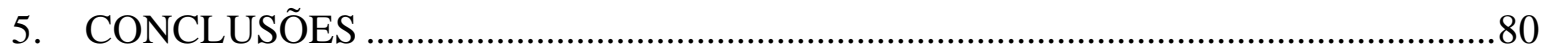

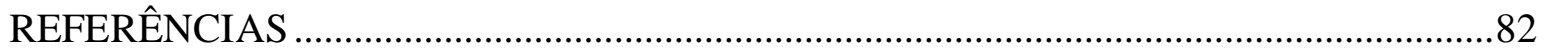




\section{INTRODUÇÃ̃O}

Com o crescimento da produção de petróleo, gás natural e biocombustíveis a demanda de dutos (oleodutos, gasodutos e álcooldutos) aumentou para viabilizar o escoamento da produção. Segundo a Agência Nacional de Petróleo, ANP (2008), somente na última década o aumento na produção de biocombustíveis foi de quase $60 \%$, enquanto que as reservas de petróleo e gás natural aumentaram em $72 \%$ e $62 \%$, respectivamente. Esses dados ainda não levam em consideração as reservas do chamado Pré-sal. Estima-se que as reservas brasileiras podem aumentar dos atuais 15 bilhões de bep (barril equivalente de petróleo) para cerca de 100 bilhões de bep e, em termos de reservas de petróleo no mundo, o país saltaria da $17^{\mathrm{a}}$ para a $5^{\mathrm{a}}$ posição, segundo dados recentes do IPEA (2009).

Comparando-se com outros meios de transporte, o baixo custo e a segurança fazem com que o sistema de dutos seja o mais utilizado para o transporte destes fluidos. Para que a qualidade e a segurança operacional e ambiental sejam asseguradas, existem normas internacionais que regulamentam a produção de dutos, que são as normas API (AMERICAN PETROLEUM INSTITUTE, 2000).

Aços API da classe 5L são do tipo ARBL (Alta Resistência e Baixa Liga), também conhecidos como aços microligados por possuírem elementos de liga em pequenas proporções, geralmente nióbio, titânio, vanádio, ou ambos, possibilitando melhor controle microestrutural e, conseqüentemente, ganhos significativos nas propriedades mecânicas (GUIMARÃES, 1997). As principais características são boa conformabilidade, boa tenacidade, boa soldabilidade e boa resistência a trincas induzidas por hidrogênio. $\mathrm{O}$ aço API 5L X65 é usado em dutos submetidos a médias e altas pressões onde a preocupação com a economia em peso é importante.

A norma API (2000) determina que a soldagem destes dutos seja feita pelos seguintes processos: $E R W$ (Soldagem por Resistência Elétrica), SAW (Soldagem por Arco 
Submerso), EIW (Soldagem por Indução Elétrica), $L B W$ (Soldagem por Feixe de Laser) e GMAW (Soldagem com Arame Sólido). Segundo diversos autores (SCHILLER, 1982; SANDERSON, 2000; KOGA, 2000), o processo de EBW é viável do ponto de vista tecnológico, porém ainda é pouco explorado.

Os parâmetros de soldagem por feixe de elétrons são fatores importantes para a geometria do cordão de solda e cada um tem uma influência significativa nas microestruturas obtidas nesta região. A tensão de aceleração responde pela aparência externa da solda e na forma da seção do cordão. A corrente elétrica do feixe responde pela quantidade de metal fundido, profundidade de penetração do cordão de solda e quantidade de metal depositado (quando se utiliza metal de adição). A velocidade de soldagem influencia na relação penetração/largura do cordão.

O material estudado nesta Dissertação foi processado via laminação controlada com resfriamento ao ar. Trata-se de uma chapa espessa do aço API 5L X65. Há poucas referências na literatura sobre este aço soldado por feixe de elétrons. Koga (2000) aborda aspectos de engenharia relacionados ao layout do posicionamento do canhão para a realização de soldas radiais em tubos com $19 \mathrm{~mm}$ de espessura. Conhecer a microestrutura presente nas regiões da solda (zona fundida e zona termicamente afetada), além da devida caracterização mecânica (PINTO, 2011), é tarefa essencial para decidir se o processo de soldagem por feixe de elétrons é adequado ou não para a fabricação de tubos para óleo e gás.

Os resultados desta Dissertação são úteis para avaliar a viabilidade técnica do uso da soldagem por feixe de elétrons neste aço e, eventualmente, de outros ainda mais resistentes, como por exemplo, os graus X80 e X100 com microestrutura bainítica. 


\section{REVISÃO DA LITERATURA}

\subsection{AÇOS ARBL}

Os aços ARBL (Alta Resistência e Baixa Liga) são utilizados com sucesso em aplicações que requerem custo relativamente baixo, boa resistência mecânica e boa tenacidade à fratura. Estes aços são empregados em tubos, vasos de pressão, estruturas navais, vagões, tanques, estruturas offshore, construção civil, componentes automotivos e outros (AKSELSEN, 1990; CHEN, 1984).

O Instituto Americano de Petróleo API (American Petroleum Institute) classifica os aços empregados na fabricação de dutos em função de sua composição química e resistência mecânica seguindo a norma API-5L. Os vários graus dos aços para tubos, especificados pela norma API 5L, podem ser classificados como aços ARBL. Usualmente, estes aços são microligados com nióbio, titânio ou vanádio, garantindo boa tenacidade à fratura, alta resistência à tração e resistência à fragilização por hidrogênio (AKSELSEN, 1990; CHEN, 1984).

Devido ao efeito de endurecimento promovido pela adição dos elementos de liga, o teor de carbono pode ser reduzido, resultando em melhor soldabilidade e boa tenacidade à fratura (AKSELSEN, 1988; AKSELSEN, 1987). A soldabilidade dos aços é fortemente dependente da composição química e pode ser quantificada por meio do cálculo do carbono equivalente, $\mathrm{C}_{\mathrm{eq}}$. $\mathrm{O}$ carbono equivalente relaciona a soldabilidade com a temperabilidade do aço. Valores elevados de $\mathrm{C}_{\mathrm{eq}}$ tornam o aço mais temperável e, consequentemente, diminui sua soldabilidade (GRONG, 1986). A relação para $\mathrm{C}_{\mathrm{eq}}$ adotada pelo International Institute of Welding (\% em peso) é a seguinte:

$$
C E=\% C+\frac{\% M n}{6}+\frac{\% C r+\% M o+\% V}{5}+\frac{\% N i+\% C u}{15}
$$


A resistência mecânica e a tenacidade à fratura resultam da combinação de uma microestrutura formada por grãos finos, alta densidade de discordâncias (geradas pela deformação a frio do material), endurecimento por precipitação (causado por carbonetos de titânio, vanádio ou nióbio, finamente dispersos na matriz), além de uma textura adequada. A adição de elementos microligantes permitiu, inicialmente, uma significativa redução no carbono equivalente. Porém, uma maior redução no carbono equivalente tornou-se possível com procedimentos de melhoria no processamento termomecânico, como a laminação controlada, dentre outros (AKSELSEN, 1988; AKSELSEN, 1990).

A escolha deste aço deve-se ao fato de que sua tecnologia de fabricação é dominada no país, sendo utilizado comercialmente na fabricação de dutos para transporte de óleo e gás. Apesar de existirem aços ainda mais resistentes das famílias X80, X100 e X120, estes aços ainda não são processados em escala comercial no país. A razão para busca constante do aumento da resistência mecânica deve-se ao fato de que tubos mais resistentes e mais leves podem ser fabricados, além de poderem suportar maiores pressões de trabalho.

Estes aços mais resistentes possuem estrutura tipicamente bainítica, contrastando com a perlítica encontrada nos aços menos resistentes. Zajac e colaboradores (2005) reportam que estruturas bainíticas refinadas e outras metaestáveis, algumas delas ainda não reportadas até o momento, são encontradas na região soldada de aços como o API 5L X120, ressaltando a necessidade da caracterização microestrutural por meio de técnicas avançadas de alta resolução.

\subsection{EVOLUÇÃO DOS AÇOS API}

Até os anos 70, os aços de alta resistência e baixa liga (ARBL), como os aços X52 e X60, eram produzidos pelo processo de laminação a quente seguida de normalização. Era necessário prevenir a formação de bandas altamente segregadas (Mn e P) que promovem 
redução na resistência à fragilização por hidrogênio. Nos anos 70, a laminação a quente e a normalização foram aperfeiçoadas pelo tratamento termomecânico, que possibilitou o desenvolvimento de aços API X70, microligados com nióbio e vanádio e menor teor de carbono. Uma melhoria no processamento, consistindo de tratamento termomecânico com subseqüiente resfriamento acelerado, possibilitou a produção de aços mais resistentes como o API X80, com menor teor de carbono e excelentes tenacidade e soldabilidade (HILLENBRAND, 2002). Adições de $\mathrm{Mo}, \mathrm{Cu}$ e $\mathrm{Ni}$, associadas a tratamentos termomecânicos com resfriamento acelerado modificado, tornaram possível o desenvolvimento dos aços API X100 e API X120 (HILLENBRAND, 2002; HILLENBRAND, 2004; BUZZICHELLI, 2002). A Figura 1 esquematiza a evolução dos aços da classe API 5L. O grau do aço, segundo a norma API 5L (2000), reflete o valor mínimo do limite de escoamento do material em [ksi], ou seja, o API grau X65 tem limite de escoamento mínimo de $65 \mathrm{ksi}(\approx 448 \mathrm{MPa})$.

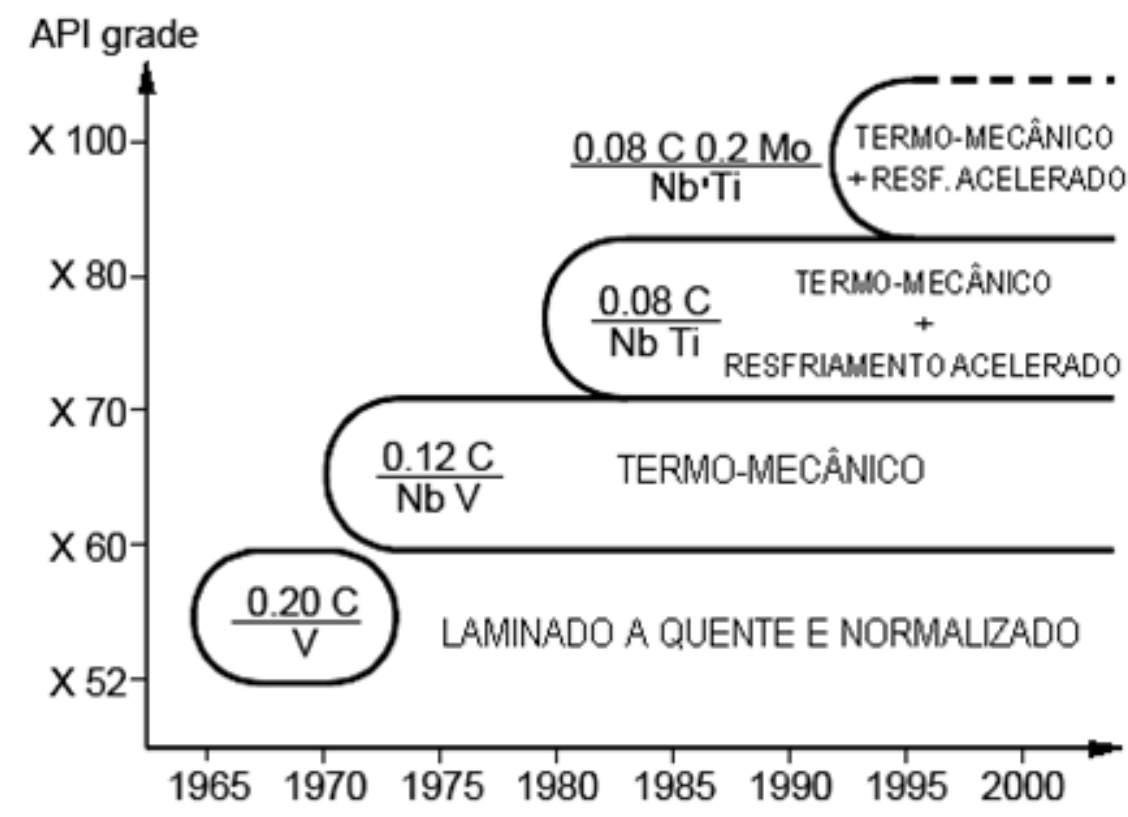

Figura 1. Desenvolvimento dos aços microligados tipo API (HILLENBRAND, 2002). 


\subsection{COMPOSIÇÃO QUÍMICA DOS AÇOS API}

A composição química do aço determina as características para sua aplicação. Em seguida, é descrita de modo resumido a influência dos principais elementos de liga nos aços da classe API:

- Carbono - O aumento do teor de carbono é a maneira mais econômica de obter resistência mecânica, principalmente no limite de escoamento; no entanto, é prejudicial à tenacidade do material. Teores elevados também comprometem a soldabilidade do aço. Quanto menor o teor de carbono, maior o tempo no qual o aço permanecerá na fase delta promovendo uma maior homogeneização do carbono. Essas características são benéficas para a zona termicamente afetada em termos de tenacidade (HULKA, 1995). Sabe-se que nos aços o elemento mais importante e que determina a microestrutura é o carbono. Em soldas, seu teor deve ser baixo, geralmente na faixa de 0,05 a $0,15 \%$, para que não haja formação de martensita. Teores mais baixos de carbono têm a função de evitar a precipitação intensa de carbonetos e também de refinar a microestrutura (RÄSÄNEM, 1972).

- Manganês - Promove o aumento da resistência mecânica e da resistência à fadiga. De acordo com a norma API 5L (2000) o limite máximo do teor de Mn no aço API 5L X65 é 1,45\%. Diminui a temperatura de transformação $\gamma \rightarrow \alpha$, promovendo o refinamento do grão ferrítico. Este refinamento aumenta a resistência mecânica e a tenacidade (CALDEIRA, 2005). O manganês combina-se com o enxofre formando MnS, produzindo inclusões alongadas no interior da matriz. Essas inclusões podem atuar como concentradores de tensão, diminuindo a ductilidade e a tenacidade (GRAY, 2007).

- Silício - Aumenta a resistência mecânica e a resistência à corrosão, mas como os elementos anteriores, o Si reduz a soldabilidade. É encontrado em solução sólida na ferrita. 
Atua como desoxidante, reduzindo a porosidade. Favorece a formação de ferrita próeutetóide e restringe a formação da austenita (GRAY, 2007).

- Enxofre - Prejudicial aos aços, pois diminui a ductilidade, a tenacidade à fratura e a soldabilidade (COSTA E SILVA, 2006).

- Fósforo - Aumenta o limite de escoamento e a resistência à corrosão, mas diminui a soldabilidade, a ductilidade e a tenacidade à fratura. Fragiliza o aço acima de determinados teores (COSTA E SILVA, 2006). Esta impureza tende a segregar durante a solidificação do aço (CALDEIRA 2005; GRAY, 2007).

- Nitrogênio - Deve estar presente em pequenas quantidades devido à sua afinidade por $\mathrm{Nb}, \mathrm{Al}, \mathrm{V}$ e Ti, causando o endurecimento por precipitação. Este endurecimento prejudica a tenacidade do aço (CALDEIRA, 2005; HONEYCOMBE, 1982; GRAY, 2007). Estes últimos elementos citados S, N, P não são adicionados ao aço com a intenção de melhoria nas propriedades e podem ser considerados como impurezas residuais.

- Nióbio - É um dos principais elementos de liga dos aços microligados, sendo quase obrigatório nos aços ARBL. Pequenos teores desse elemento aumentam os limites de resistência e de escoamento. Permite diminuir os teores de carbono e manganês. O uso de $\mathrm{Nb}$ viabilizou a fabricação de aços com menor carbono (IMLAU, 2007);

- Titânio - Aumenta o limite de resistência e melhora o desempenho em temperaturas elevadas. Estabiliza a ferrita e em concentrações mais elevadas diminui a extensão do campo austenítico (HONEYCOMBE, 1982).

- Vanádio - O vanádio é um estabilizador de ferrita. Pode formar VC e VN durante e após a transformação $\gamma \rightarrow \alpha$. Esses precipitados se formam em temperaturas mais baixas e, portanto, são mais finos (KORCHYNSKY, 2000). 
A soma das quantidades de $\mathrm{Nb}$, Ti e $\mathrm{V}$ deve ser de no máximo $0,1 \%$, para que o endurecimento não seja elevado demais prejudicando as propriedades do material, em especial a tenacidade à fratura.

\subsection{LAMINAÇÃO CONTROLADA}

Os aços ARBL são produzidos pelo processo de laminação controlada. O processo consiste em laminar o aço a quente com passes controlados seguido de resfriamento acelerado ou ao ar. A microestrutura final depende da forma como este é conduzido.

Nos anos 70, surgiu o processo de laminação termomecânica controlada (TMCR), representado na Figura 2, o que permitiu eliminar o tratamento de normalização no final da etapa de laminação iniciando a era dos aços API 5L (BATISTA, 2003). Devido à introdução deste processo de laminação a quente com resfriamento controlado, combinado com a adição de microligantes, foi possível um ganho nas propriedades mecânicas, incluindo a soldabilidade, a tenacidade e a resistência mecânica dos aços. O processo de laminação controlada permite diminuir significativamente o tamanho de grão da austenita, que promove após sua transformação uma microestrutura ferrítica refinada, conferindo elevada tenacidade ao produto final (GORNI, 1999). 


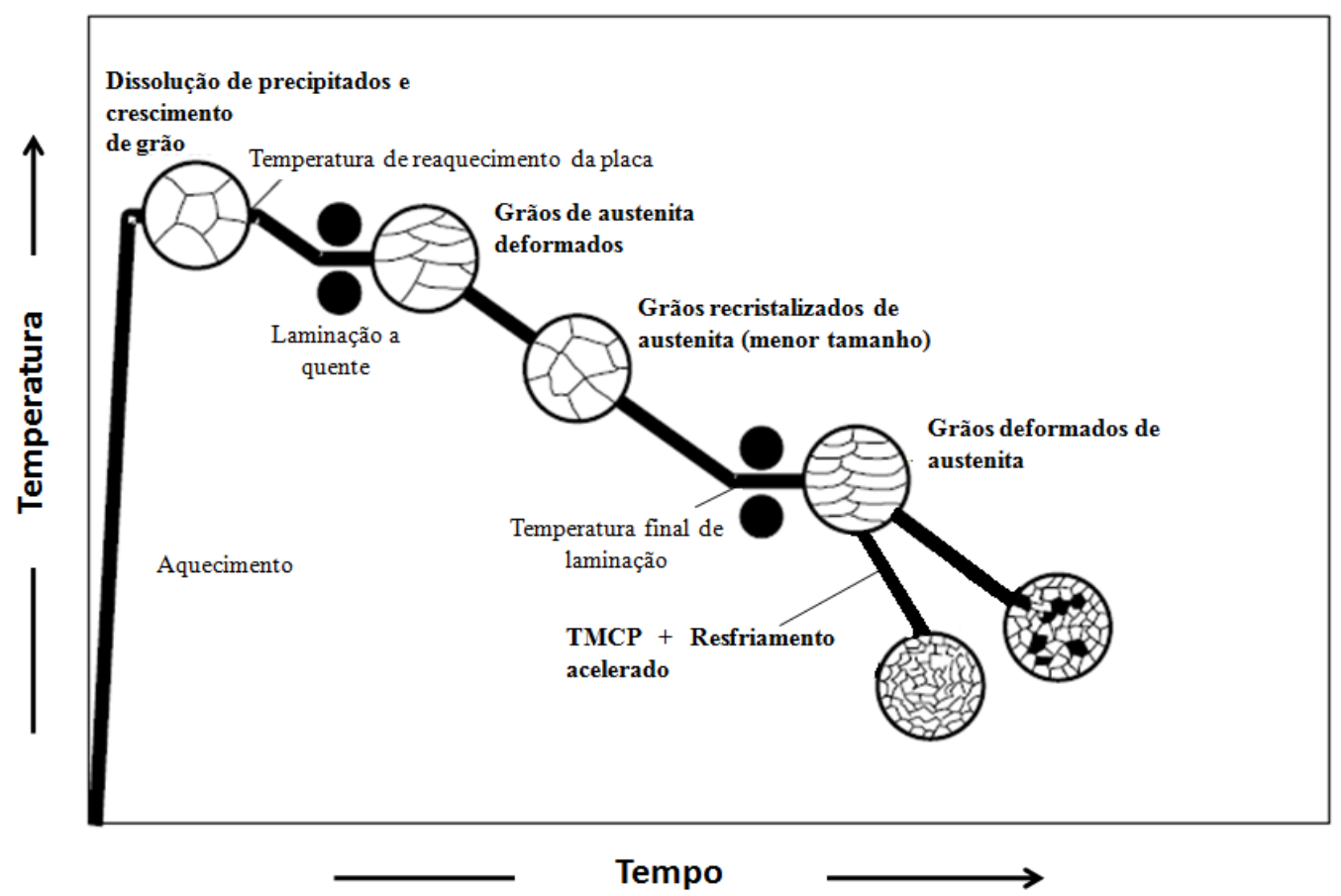

Figura 2. Processo de laminação controlada com e sem o resfriamento acelerado (Adaptado de Hillenbrand, 2001).

O processo de laminação controlada ocorre em três etapas. A primeira etapa se dá por volta de $1200^{\circ} \mathrm{C}$ onde ocorre a deformação da austenita. A cada passe, a austenita deformada se recristaliza e promove o refino de grão pela combinação de ciclos sucessivos de deformação e recristalização. A etapa seguinte de laminação ocorre em temperaturas intermediárias, por volta de $900^{\circ} \mathrm{C}$, onde não mais ocorre a recristalização da austenita, preservando assim a microestrutura no estado deformado. A austenita deformada sofre encruamento, o qual se acumula à medida que os passes de laminação são realizados aumentando o número de sítios disponíveis para a nucleação da ferrita (PLAUT et al, 2009). A temperatura de recristalização da austenita aumenta nestes materiais pela adição de microligantes, principalmente o nióbio. Na última etapa, já em temperaturas mais baixas, a microestrutura consiste de grãos de ferrita e austenita deformados. A austenita ainda não transformada sofre um encruamento adicional, criando ainda mais sítios de nucleação para a ferrita, além de uma microestrutura de grãos bastante refinada. A ferrita também encrua promovendo um aumento da resistência do material (PLAUT et al., 2009). 
A última fase consiste no resfriamento acelerado que produz uma microestrutura bastante fina composta de ferrita, bainita e/ou martensita. Para um resfriamento convencional (ao ar) a microestrutura final típica encontrada para estes aços consiste de ferrita e perlita.

O tamanho de grão final da ferrita depende da taxa de nucleação e do crescimento da ferrita na austenita, bem como da composição química do material. Segundo Cuddy (1982) os elementos de liga influenciam na temperatura de recristalização da austenita. Esses elementos elevam a temperatura de não-recristalização da austenita, permitindo que a laminação seja efetuada em temperaturas mais elevadas com menor desgaste dos cilindros de laminação, além de permitir que seja mantida a estrutura de grãos deformados nesta temperatura. A Figura 3 mostra a influência dos elementos microligantes na temperatura de recristalização da austenita.

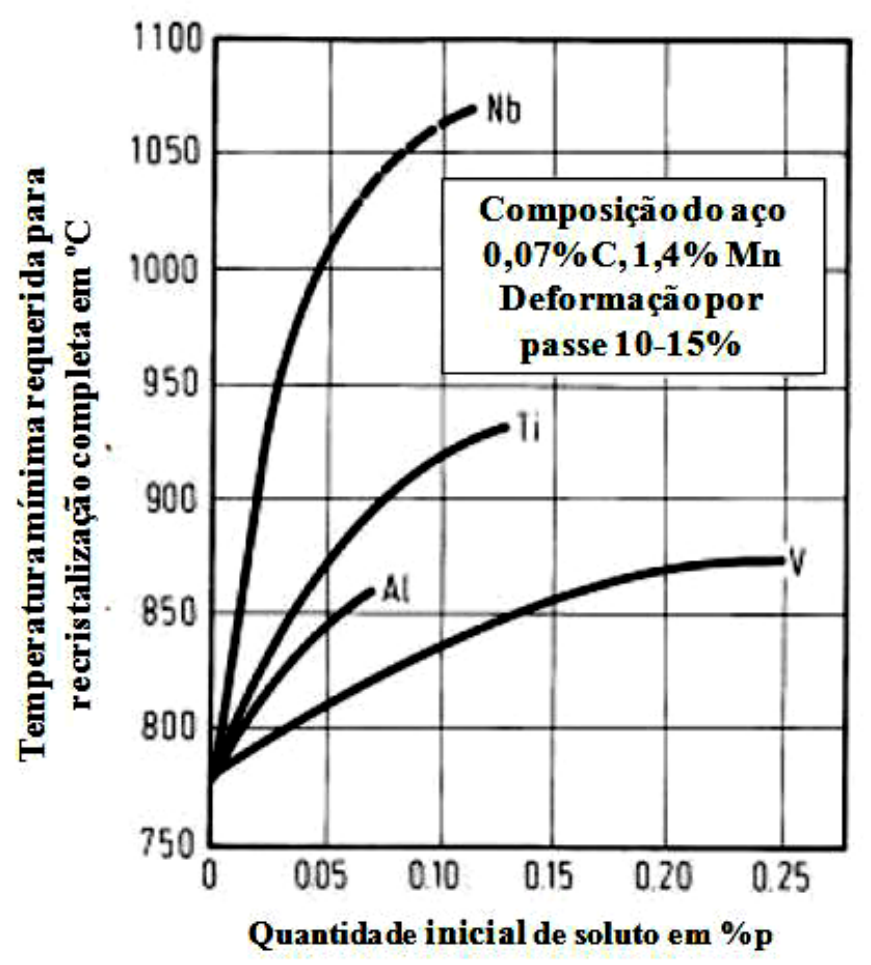

Figura 3. Influência da adição de microligantes na temperatura de recristalização de austenita (CUDDY, 1982). 


\subsection{SEGREGAÇÃO}

Em aços, é muito comum a ocorrência de segregação de elementos de liga como Mn, e também de impurezas adicionais P e S. Essa segregação ocorre durante a solidificação no lingotamento contínuo dos aços. A segregação consiste no enriquecimento e/ou expulsão de um dado elemento de liga à medida que a solidificação ocorre, levando ao surgimento de um perfil de composição no lingote.

Durante a solidificação, os elementos de liga podem segregar para a interface sólidolíquido tanto em longo alcance (macrossegregação) ou de curto alcance (microssegregação). É comum ocorrer à segregação de manganês na zona central de chapas laminadas a quente e este evento está associado à macrossegregação.

\subsection{PROCESSOS CONVENCIONAIS DE SOLDAGEM DE TUBOS}

Por conta da grande demanda de tubos para transporte de óleo e gás, o mercado está cada vez mais voltado para os processos de soldagem e pelo desenvolvimento de novas tecnologias para atender as necessidades do país em termos de aumento da escala.

A soldagem pode ser definida como uma operação que visa obter a união de duas ou mais peças assegurando na junta soldada uma integridade química, física e metalúrgica. Dentre os processos de soldagem de tubos, os mais utilizados industrialmente são a soldagem por arco submerso (SAW) e a soldagem por resistência elétrica (ERW). A importância de conhecer cada um deles e entender seu funcionamento nos permite avaliar as condições favoráveis ou não de desenvolver outras técnicas capazes de suprir o que se deseja. 


\subsubsection{Soldagem por arco submerso (SAW - Submerged Arc Welding)}

A soldagem por arco submerso é um processo de junção de peças metálicas produzido pelo calor gerado por um arco elétrico formado entre o arame contínuo (filler) e a peça. $\mathrm{O}$ arco elétrico e a poça de fusão são protegidos por um fluxo granular que funde próximo ao arco, criando uma escória protetora. Esta escória é removida posteriormente.

Este processo permite utilizar elevadas correntes de soldagem levando a uma elevada taxa de deposição do arame contínuo, preenchendo as juntas soldadas. A utilização deste processo é dada na forma mecanizada ou automática, mas também existem equipamentos que permitem soldar de maneira semi-automática.

Devido à utilização de um fluxo líquido neste processo, as posições de soldagem estão limitadas à plana para chapas e tubos e horizontal para soldas filetes. Em tubos, este processo permite realizar soldas circunferenciais e também longitudinais (paralela ao eixo principal do tubo e à direção de laminação).

O processo de arco submerso é o mais utilizado para a soldagem de tubos em indústrias por apresentar muitas vantagens. Produz soldas com excelente acabamento e uniformidade, elevadas velocidades de soldagem e altas taxas de adição de material, livre de respingos e fumos, além de dispensar qualquer proteção contra radiação pelo fato de o arco estar submerso (MODENESI, 2000). Nas indústrias de tubos este é o processo mais utilizado devido à elevada produtividade com a excelente combinação de vantagens.

\subsubsection{Soldagem por resistência elétrica (ERW - Electric Resistence Welding)}

A soldagem por resistência elétrica é um processo de junção onde o calor é gerado pela passagem de corrente elétrica e aplicação simultânea de pressão. As peças são aquecidas e a fusão é local (WAINER, 1992). A aplicação mais importante deste processo é 
a fabricação de tubos, onde as chapas são conformadas e, na etapa final, as duas bordas são pressionadas uma contra a outra, enquanto dois eletrodos circulares executam a solda.

A utilização deste processo nas indústrias fabricantes de tubos é bastante difundida pelas vantagens de produção em termos de economicidade e rapidez. Dependendo da espessura do material a ser soldado, este processo pode não atingir a qualidade necessária para a solda de tubos. Este processo é utilizado na soldagem longitudinal de tubos.

\subsection{SOLDAGEM POR FEIXE DE ELÉTRONS (EBW - ELECTRON BEAM WELDING)}

A soldagem por feixe de elétrons é comumente utilizada em soldas que exigem grande penetração num único passe. A soldagem por feixe de elétrons é um processo de alta energia que ocorre devido à transformação da energia cinética dos elétrons em calor devido à colisão dos elétrons com a superfície do material a ser soldado (SCHILLER, 1982).

Pelo fato de toda a energia do feixe se concentrar numa pequena região, a soldagem por feixe de elétrons produz cordões de solda mais profundos (elevada penetração) e mais estreitos que os processos convencionais a arco. Assim, a elevada razão penetração/largura do cordão, o baixo aporte térmico e a mínima distorção são as principais vantagens desta técnica (BIRNIE, 1976). As principais vantagens desta técnica são as seguintes:

a) A geração de um feixe estreito com grande densidade de potência permite a soldagem de chapas espessas (> $100 \mathrm{~mm})$, dependendo da tensão de aceleração (BIRNIE, 1976). A densidade de potência na soldagem por feixe de elétrons é da ordem de $10^{11} \mathrm{~W} / \mathrm{m}^{2}$, muito maior que a encontrada na soldagem por arco submerso $\left(10^{7} \mathrm{~W} / \mathrm{m}^{2}\right)(\mathrm{KOU}, 2003)$; 
b) a possibilidade da soldagem de materiais dissimilares ( $S U N, 1996)$, sem a necessidade de material de adição, além de ser uma técnica praticamente livre de oxidação, uma vez que o processo ocorre em alto-vácuo;

c) a velocidade de soldagem, a reprodutibilidade do processo e a profundidade de penetração caracterizam a técnica como superior ao processo de soldagem por feixe de laser e outros como a soldagem por arco submerso (BIRNIE, 1976);

d) a zona afetada pelo calor é pequena e estreita (WAINER, 1992);

e) A distorção gerada pelo processo é muito pequena (WAINER, 1992).

O processo EBW necessita de uma câmara de vácuo para que não ocorra a dispersão do feixe de elétrons. Pressões típicas nas câmaras de soldagem são da ordem de $5.10^{-4}$ mbar (alto-vácuo), médio-vácuo $\left(5 \times 10^{-2}\right.$ mbar) e baixo-vácuo (próximo à pressão atmosférica) (SANDERSON, 2000). Este processo é utilizado na junção de diversos tipos de metais e ligas. É possível soldar aços em geral, ligas resistentes ao calor, metais refratários, berílio, titânio e suas ligas, além do cobre e suas ligas (ASM, 1983; SCHILLER, 1982). Com um feixe menos focalizado pode-se obter menor concentração de energia e operar o processo de forma similar à soldagem a arco.

Um dos fatores que ainda limitam a popularização do processo EBW é a necessidade de câmaras de vácuo para soldagens. Para a solução deste problema novas tecnologias estão sendo desenvolvidas, tais como o uso de cortinas de plasma ao invés de câmaras de vácuo. Essa medida pode tornar a técnica mais viável dos pontos de vista econômico e tecnológico na fabricação de dutos (HERSHCOVITCH, 2005). Outra solução poderia ser o uso de câmaras auxiliares para o estabelecimento de um pré-vácuo nas peças antes de sua soldagem ou pelo uso de equipamentos que trabalham com pressões mais elevadas $(A W S$, 1991). 
Com o recente desenvolvimento de chapas de aço ARBL da geração X120 (microestrutura bainítica) para a fabricação de tubos, o método de soldagem usualmente utilizado (SAW, com passes múltiplos e metal de adição - arames) enfrenta dificuldades técnicas, uma vez que o elevado aporte térmico deste processo promove o amolecimento das áreas adjacentes ao cordão de solda (HILLENBRAND, 2004) por meio de engrossamento microestrutural (crescimento de grão e formação de perlita), eliminando todas as vantagens da microestrutura bainítica $(\mathrm{MB})$. Esta técnica foi escolhida para a presente Dissertação por apresentar baixo aporte térmico, uma zona termicamente afetada (ZTA) pequena, além de permitir a soldagem de chapas bastante espessas num único passe.

\subsection{PARÂMETROS DE SOLDAGEM}

Os parâmetros de soldagem influenciam a geometria dos cordões de solda. Cada um responde por um efeito, influenciando de maneira positiva ou não as propriedades do cordão de solda. A tensão de aceleração responde pela forma da seção e aparência externa do cordão de solda. No caso da soldagem por feixe de elétrons a tensão de aceleração deve ser elevada para garantir que o bombardeio de elétrons na peça seja suficiente para garantir a fusão do material e assim ocorrer a união do que se deseja soldar.

A corrente de soldagem é a variável mais importante dentre os parâmetros. Ela responde pela quantidade de metal fundido, pela profundidade de penetração do cordão e quando se utiliza metal de adição é a variável que dita a quantidade de metal depositado. Se esta variável não for escolhida de maneira adequada poderão existir defeitos como falta de fusão e falta de penetração, diminuindo a qualidade da região soldada. A velocidade de soldagem influencia a relação penetração/largura do cordão de solda. Este parâmetro deve ser bem controlado para evitar soldas largas e, portanto, o aumento da ZTA. 


\subsection{TRANSFERÊNCIA DE CALOR NO PROCESSO DE SOLDAGEM}

O calor é o elemento essencial nos processos de junção, mas também pode ocasionar problemas por influenciar diretamente as transformações metalúrgicas e os fenômenos termomecânicos na região de solda. Tais efeitos estão relacionados ao ciclo da soldagem e as temperaturas às quais a região de solda é submetida (TANIGUCHI, 1976). Alguns fatores importantes devem ser levados em conta no estudo de transferência de calor em materiais soldados, os quais são citados a seguir.

a) Aporte térmico ao material soldado, também conhecido como insumo de calor ou de energia (heat input);

b) Distribuição e picos de temperatura (ciclo térmico) durante a soldagem;

c) Tempo de residência nestas temperaturas;

d) Velocidade de resfriamento da região de solda

Após a soldagem, a dissipação de calor ocorre por meio de condução na peça. Comparada aos outros processos de soldagem por fusão, a soldagem EBW se destaca por apresentar uma região afetada pelo calor bastante estreita. Isso está relacionado, principalmente com a elevada potência do processo (SCHILLER, 1982). A Figura 4 compara a potência específica para alguns processos de soldagem. 


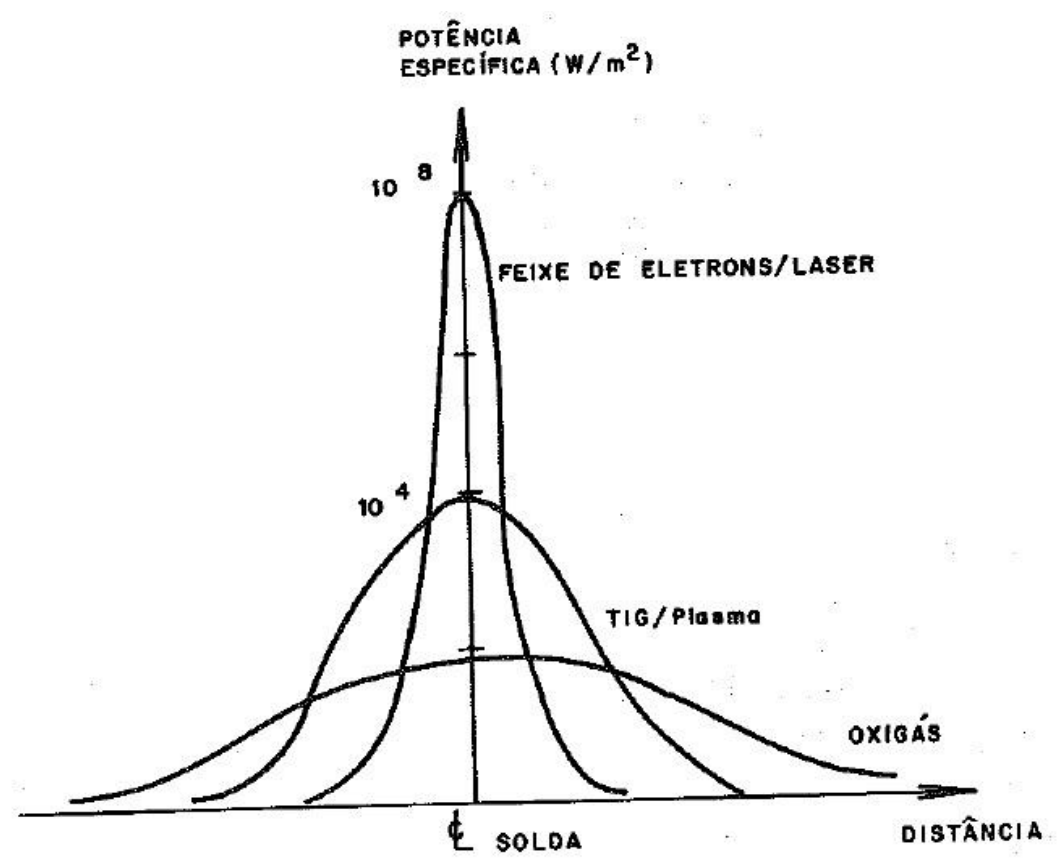

Figura 4. Potência específica em função do processo de soldagem (Adaptado de Rykaline, 1974).

\subsection{EFEITOS TÉRMICOS NO CORDÃO DE SOLDA}

Comparado com outros processos de soldagem por fusão, a soldagem por feixe de elétrons destaca-se pela capacidade de restringir regiões aquecidas substancialmente nas proximidades da solda. Isso ocorre, principalmente, devido sua elevada densidade de energia e ao efeito "keyhole” intrínseco ao processo (SCHILLER, 1982).

Para calcular a taxa de resfriamento sofrida pelo material quando soldado, algumas considerações são tomadas com o auxílio de equações deduzidas de forma a simplificar o processo de transferência de calor durante e após o processo de soldagem.

No caso de aços, a temperatura no centro da solda pode ser estimada pela Equação 1. Nesta equação são relacionados diversos parâmetros do processo de soldagem, tais como: tensão de aceleração, $U_{b}(V)$; corrente de soldagem, $I_{b}(A)$; velocidade de soldagem, $v_{s}$ (m/s); e fatores como penetração do cordão, s (m) e o tempo de soldagem, t (s). 


$$
T(x)=T_{0}+1,67 * 10^{-5} * \frac{U_{b} * I_{b}}{v_{s} * s * \sqrt{t}}
$$

Conforme Schiller (1982), a Equação 2 descreve a energia usada na soldagem por unidade de comprimento do cordão de solda ou aporte térmico:

$$
e_{m}=\frac{\eta * U_{b} * I_{b}}{v_{s}}
$$

O parâmetro $\eta$ corresponde à eficiência do processo de soldagem, que no caso da EBW responde por $80 \%$. A partir das equações 1 e 2 é possível que se estime a taxa de resfriamento para um aço soldado por EBW, de acordo com a Equação 3.

$$
\frac{d T}{d x}=1,8 * 10^{9} \frac{\left(T-T_{0}\right)^{3}}{\left(\frac{e_{m}}{s}\right)^{2}}
$$

A taxa de resfriamento é sempre maior nas proximidades da frente de solidificação, onde a temperatura é quase a mesma da temperatura de soldagem, e em seguida cai rapidamente conforme o resfriamento prossegue. Quanto menor for o aporte térmico, maior é a taxa de resfriamento, referindo-se à penetração ou à espessura da placa. (SCHILLER, 1982). A taxa de resfriamento é importante no caso de materiais transformáveis, como é o caso dos aços baixo carbono. Os processos de transformação na zona fundida e na zona termicamente área afetada (ZTA) são dependentes da velocidade na qual são atingidas temperaturas críticas para um dado material (SCHILLER, 1982). 
A partir das curvas TTT é possível determinar a ocorrência da transformação estrutural e também levantar a dureza aproximada se a taxa de resfriamento é conhecida (SCHILLER, 1982). Com estes dados é possível desenvolver diagramas de resfriamento contínuo (TRC) como o mostrado na Figura 5.

Conhecendo-se a taxa de resfriamento sofrida pelo aço em estudo, torna-se mais simples estimar quais são as possíveis microestruturas formadas neste aço quando submetidas ao processo de soldagem e posterior resfriamento, conforme indicado na Figura 6, que mostra as microestruturas esperadas em função da taxa de resfriamento aplicada para um aço API-5L X65 numa sequiência de curvas levantadas pela própria USIMINAS. Essas curvas para o aço em questão são importantes, pois permitem comparar os resultados experimentais obtidos com as taxas de resfriamento esperadas na soldagem por feixe de elétrons.

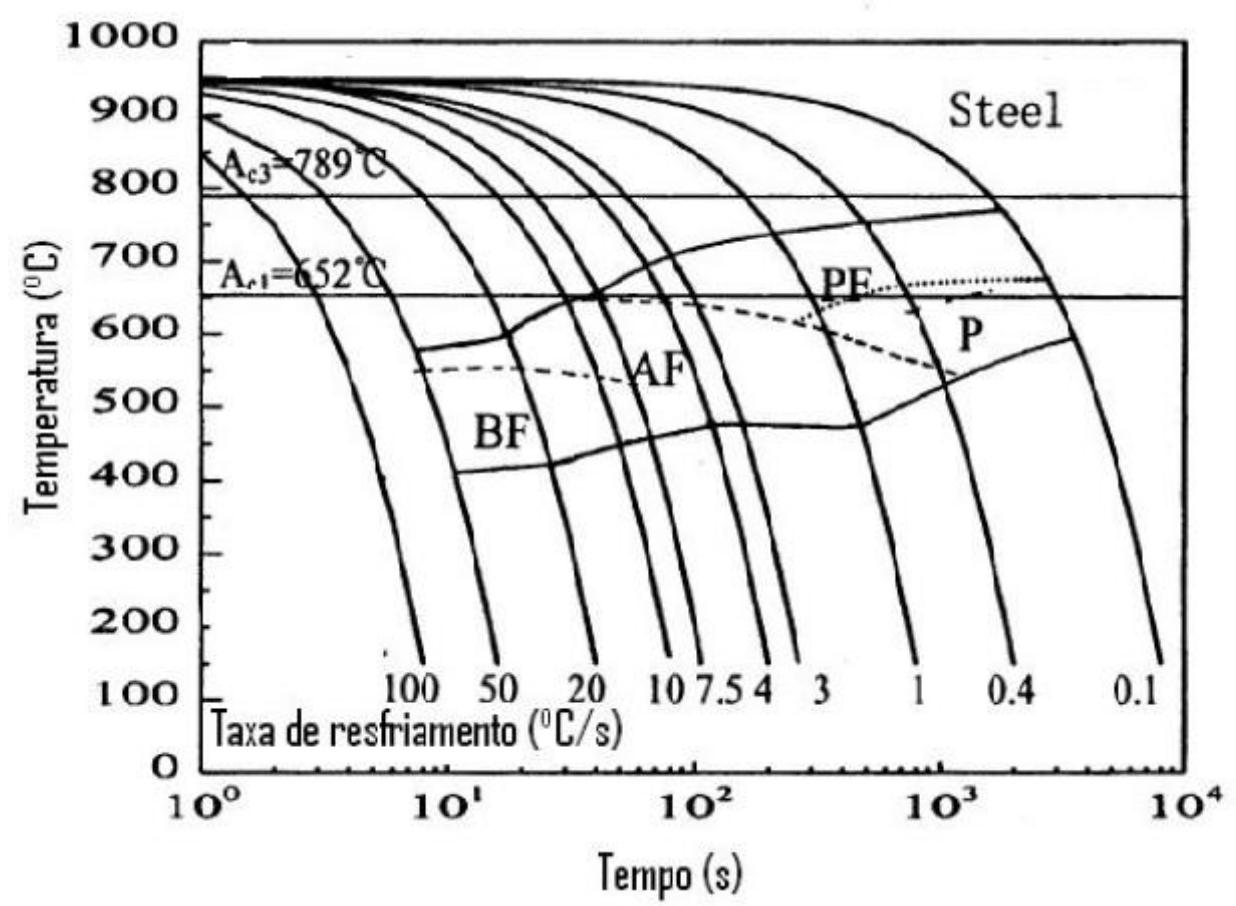

Figura 5. Diagrama TRC para um aço microligado. BF: Ferrita Bainitica; AF: Ferrita Acicular; PF: Ferrita Poligonal e P: Perlita (ZHAO, 2003). 


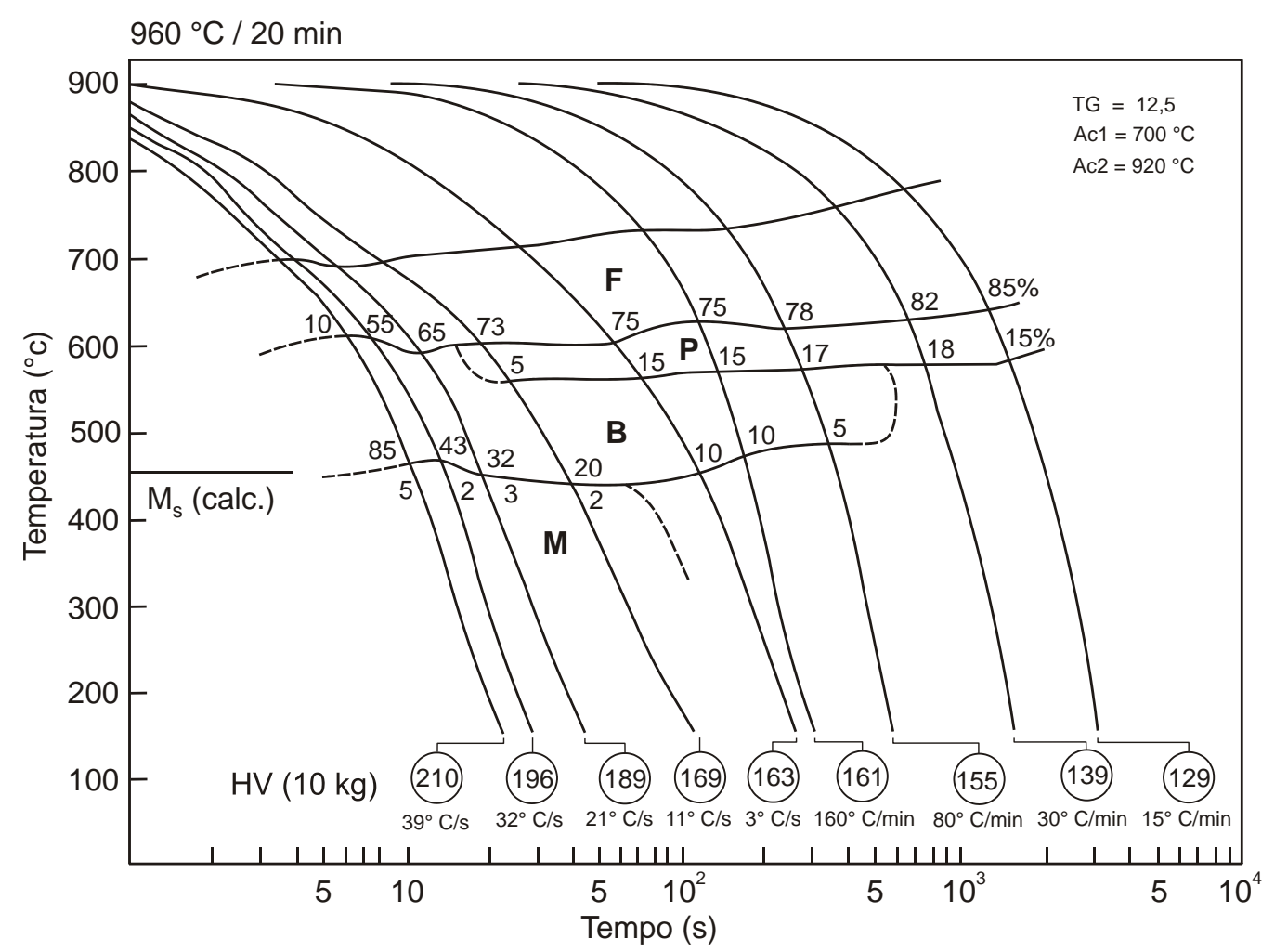

Figura 6. Curva CCT do aço em estudo API 5L X65, construída pela Usiminas ( $\mathrm{F}=$ ferrita, $\mathrm{P}=$ perlita, $\mathrm{B}=$ bainita e $\mathrm{M}=$ martensita). Os números indicam as frações volumétricas de cada constituinte.

\subsection{MICROESTRUTURA DE JUNTAS SOLDADAS}

A microestrutura de uma junta soldada de um aço ARBL deve apresentar propriedades próximas das encontradas no metal-base. Quando um aço ARBL é soldado, este sofre mudanças microestruturais durante o aquecimento e o resfriamento. Essas mudanças microestruturais devem-se à solubilização do carbono na austenita no aquecimento e posterior transformação de austenita em ferrita no resfriamento. Na maioria dos casos, dependendo das taxas de resfriamento e da composição do aço, os constituintes formados são perlita e bainita. Para taxas mais aceleradas e maiores teores de carbono no aço, a fase metaestável martensita pode ser formada.

$\mathrm{Na}$ caracterização microestrutural de uma junta soldada, as regiões de maior interesse são a ZF e a ZTA. A ZF é a região que fundiu sob ação de uma fonte térmica e suas 
características são de uma microestrutura típica de solidificação. A ZTA, por outro lado, é representada pelas regiões que estão muito próximas a região soldada, onde o aporte térmico modifica a microestrutura sem que ocorra a fusão do metal (BHADESHIA, 2006).

As transformações do metal de solda durante o resfriamento ocorrem em condições fora de equilíbrio devido às elevadas taxas de resfriamento. Com o resfriamento, diversos constituintes e fases são formados ao longo da junta soldada e seus componentes majoritários são determinados por ferrita alotriomórfica, ferrita de Widmanstätten e ferrita acicular. A Figura 6 apresenta a formação destas microestruturas principais. Pode existir também a formação de bainita (superior e inferior), martensita, constituintes M-A (martensita-austenita retida) e perlita degenerada, sendo estes últimos microconstituintes presentes em pequenas frações. A classificação da microestrutura de uma junta soldada é descrita a seguir e vale lembrar que esta varia com a literatura.

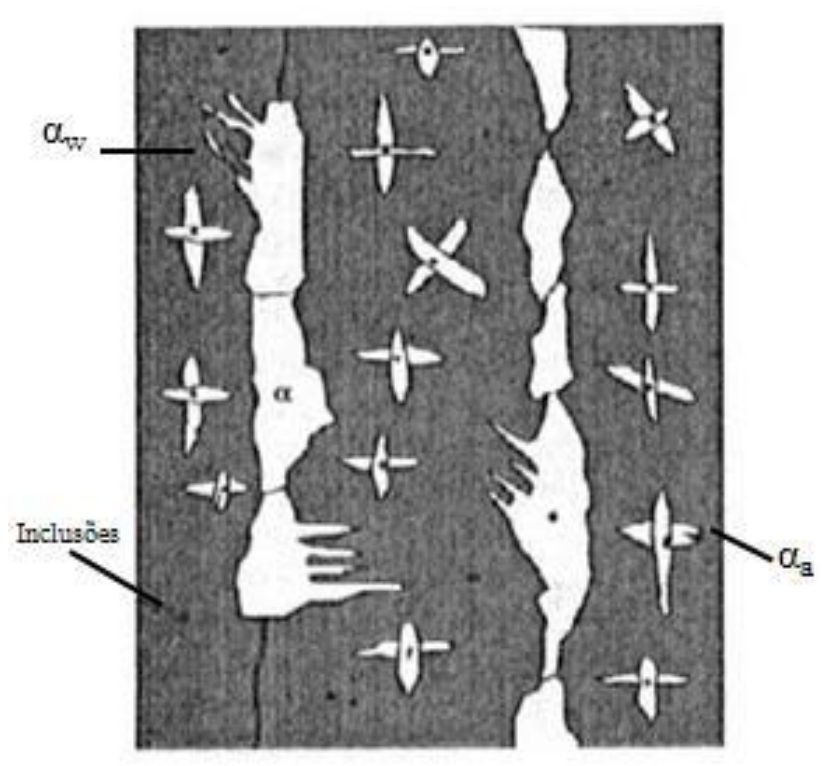

(a)

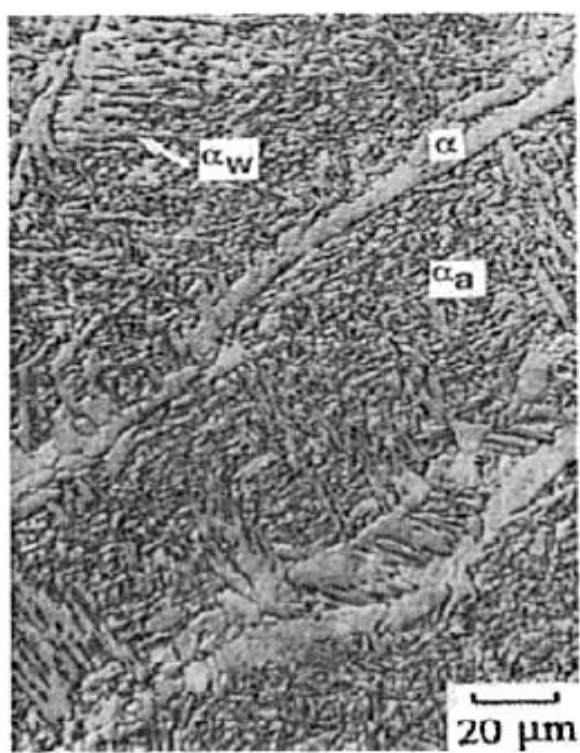

(b)

Figura 7. (a) Esquema dos constituintes essenciais da microestrutura nos grãos austeníticos colunares do aço soldado. (b) Microestrutura via MEV de um aço soldado (cortesia de Rees). Os termos $\alpha, \alpha_{\mathrm{w}}$, e $\alpha_{\mathrm{a}}$ referem-se à ferrita alotriomórfica, ferrita de Widmanstätten e ferrita acicular, respectivamente (BHADESHIA, 2006). 
A ferrita alotriomórfica $(\alpha)$ é a primeira fase a se formar durante o resfriamento da austenita e sua nucleação ocorre a partir dos contornos de grãos austeníticos, abaixo da temperatura $\operatorname{Ar}_{3}(\gamma \rightarrow \alpha)$. As camadas de ferrita alotriomórficas engrossam a uma taxa que é controlada pela difusão de carbono na austenita à frente da interface de transformação (BHADESHIA, 2006).

A ferrita de Widmanstätten $\left(\alpha_{\mathrm{w}}\right)$ pode ser classificada como primária ou secundária. A primária cresce diretamente a partir dos contornos de grão austeníticos, enquanto que a secundária se desenvolve a partir da ferrita alotriomórfica já existente. Em temperaturas inferiores a $600{ }^{\circ} \mathrm{C}$, o crescimento difusional da ferrita diminui de tal forma que seja atingida a espessura limite das camadas da ferrita alotriomórfica. Sendo assim, a ferrita de Widmanstätten é formada uma vez que a transformação não envolve a difusão de solutos substitucionais devido às temperaturas mais baixas (BHADESHIA, 2006).

A quantidade de ferrita de Widmanstätten que se forma numa junta soldada não tem correlação direta com a taxa de crescimento de suas placas. Isso ocorre, pois existe uma competição entre o crescimento das placas de ferrita de Widmanstätten, que crescem a partir dos contornos de grão austeníticos, com as placas de ferrita acicular que nucleiam nas interfaces metal-inclusão em toda a solda. Logo, diz-se que a formação de ambas as fases é um processo competitivo. Dessa maneira, qualquer fator que aumente o número de inclusões não-metálicas em relação aos sítios de nucleação nos contornos de grãos austeníticos favorece a formação da ferrita de Widmanstätten. Por outro lado, o refinamento no tamanho de grão austenítico ou uma redução na fração de inclusões geradas na solda leva à diminuição na quantidade de ferrita acicular (BHADESHIA, 2006).

A ferrita acicular $\left(\alpha_{\mathrm{a}}\right)$ nucleia preferencialmente em inclusões não-metálicas e cresce radialmente em forma de agulhas. Apresenta o mesmo mecanismo de formação da bainita; a principal diferença está nos sítios de nucleação. Este microconstituinte merece destaque 
por conferir à solda excelente tenacidade à fratura, já que esta propriedade é a mais crítica em materiais soldados. É formada durante o resfriamento do metal de solda na faixa de 650 a 500 C (COSTA E SILVA, 2006; WAINER, 1992). Ferrante e Farrar (1982) sugerem que a ferrita acicular é um microconstituinte entre a ferrita pró-eutetóide e a bainita, teoria que é também defendida por Yang e Bhadeshia (1986) e Strangwood e Bhadeshia (1986).

A bainita é um constituinte formado pela decomposição da austenita em temperaturas de 540 a $300^{\circ} \mathrm{C}$ (bainita superior) e de 300 a $200^{\circ} \mathrm{C}$ (bainita inferior), dependendo da composição do aço. Na bainita inferior, a cementita precipita tanto entre as agulhas de ferrita como em seu interior, devido à difusão de carbono ser menor em temperaturas mais baixas. Sendo assim, a bainita inferior apresenta-se com melhor tenacidade à fratura por apresentar carbonetos mais finos, dificultando a nucleação de trincas. Consiste de ripas paralelas ou agulhas de ferrita separadas por partículas alongadas de cementita. O processo para sua formação é misto, envolvendo difusão e cisalhamento. Nenhuma fase proeutetóide se forma com a bainita (WAINER, 1992; COSTA E SILVA, 2006).

Considera-se que até cerca de $500^{\circ} \mathrm{C}$ a maior parte da austenita tenha sido consumida. A pequena quantidade de austenita restante (cerca de 5\%) é enriquecida em carbono e pode se transformar em martensita, ou em perlita, a qual se encontra na forma degenerada, pois não têm a oportunidade de estabelecer uma estrutura lamelar. Em taxas de resfriamento mais lentas, a formação de perlita é favorecida em relação à martensita. Alguma austenita também pode estar presente em temperatura ambiente (BHADESHIA, 2006). Quando esta austenita retida está combinada a uma pequena fração de martensita esta morfologia é conhecida por constituintes M-A, que são duros e comportam-se como inclusões frágeis.

A perlita degenerada consiste de blocos de ferrita e colônias de cementita grosseira Geralmente, esta morfologia é encontrada na ZTA, que atinge uma temperatura suficiente 
alta para promover a degradação da estrutura lamelar da perlita (FURUHARA, et al., 2007).

Por causa das elevadas taxas de resfriamento encontradas na soldagem por feixe de elétrons, é comum nas regiões da solda a formação de bainita e do constituinte M-A, principal responsável pela diminuição da tenacidade à fratura (BAYRAKTAR, 2004).

De um modo geral, os constituintes M-A estão localizados no interior das colônias bainíticas e nos contornos de grão ferríticos. Esta associação é feita, pois na formação destas fases ocorre a partição de carbono para a austenita que ainda não se transformou. Dessa maneira, regiões da austenita ficam ricas em carbono e não são capazes de se transformar em bainita ou ferrita e, consequentemente, esta região supersaturada em carbono se transforma em martensita e parte fica retida na forma de austenita no resfriamento (KRAUSS, 1995).

\subsubsection{Transformações na ZTA}

Em uma junta soldada, a região mais crítica em termos de comportamento mecânico é a ZTA. Esta região é muito heterogênea e suas propriedades variam ao longo de sua extensão. Nos aços carbono, a ZTA pode ser dividida em até quatro regiões. Estas regiões são apresentadas a seguir e podem ser observadas nas Figuras 8 e 9.

Região de crescimento de grão: São regiões adjacentes à linha de fusão, aquecidas até temperaturas suficientemente altas capazes de transformar toda ferrita em austenita. A faixa de temperatura para ocorrer esta transformação é de 1500 a $1100{ }^{\circ} \mathrm{C}$. O crescimento de grão e o produto da decomposição da austenita durante o resfriamento determinarão as propriedades mecânicas nesta região (WAINER, 1992). A importância da zona onde ocorre o crescimento de grão está na diminuição das propriedades mecânicas durante a transformação da austenita no resfriamento. A estrutura de grãos grosseiros leva a um aumento da temperabilidade, pois é mais difícil ocorrer a transformação em produtos 
intermediários, de modo que a martensita e outras fases duras podem se formar no resfriamento. O processo de soldagem pode introduzir hidrogênio atômico na região soldada (soldas realizadas sob vácuo não apresentam esse problema), que é capaz de se difundir rapidamente na ZTA. Microestruturas mais duras são particularmente mais susceptíveis à fragilização por hidrogênio e a fratura ocorre após a junta soldada ser resfriada, ou seja, depois que o material se encontra frio. A fragilização causada pelo hidrogênio é conhecida como "trinca a frio". É devido a este motivo também, que o $\mathrm{C}_{\mathrm{eq}}$. no aço deve ser mantido suficientemente baixo para impedir o aumento da dureza na região de crescimento de grão (BHADESHIA, 2006).

Região de refino de grão: Ocorre em faixas de temperatura da ordem de $1100^{\circ} \mathrm{C}$ a $900^{\circ} \mathrm{C}$. Esta região é caracterizada por grãos de austenita de tamanho $20-40 \mu \mathrm{m}$. A estrutura de grãos e a temperabilidade não são muito diferentes daquelas associadas às operações de laminação controlada durante a fabricação das chapas de aço. Os grãos finos de austenita se transformam em ferrita ainda mais fina com uma morfologia desejável, mais macia e com maior tenacidade (BHADESHIA, 2006). Essa região refinada apresenta elevadas resistência mecânica e ductilidade (R̈̈S̈̈NEM, 1972).

Região parcialmente transformada: Ocorre em temperaturas da ordem de 900 e $750^{\circ} \mathrm{C}$. Esta região está distante da linha de fusão e a temperatura na qual ela atinge não é suficiente para que ocorra a transformação completa da austenita. A austenita que se forma tem elevado teor de carbono. O comportamento da transformação da austenita rica em carbono é diferente, pois ela tem maior temperabilidade. Logo, se a taxa de resfriamento é elevada, a austenita rica em carbono se transforma parcialmente em martensita e o restante de austenita fica retida em temperatura ambiente. Essas pequenas regiões de martensita são locais frágeis e são considerados como concentradores de tensão. Todavia, se a taxa de resfriamento não for alta o bastante para causar à transformação martensítica, a austenita 
rica em carbono pode se decompor numa mistura de ferrita e cementita grosseiras. As partículas grosseiras de cementita podem atuar como locais frágeis na microestrutura (BHADESHIA, 2006). Logo, essa região apresenta propriedades mecânicas inferiores ao metal-base (WAINER, 1992).

Região revenida: Ocorre em temperaturas entre 750 e $700^{\circ} \mathrm{C}$. Quando a temperatura atinge limites inferiores à temperatura $\mathrm{A}_{\mathrm{r} 1}\left(723^{\circ} \mathrm{C}\right)$, o efeito do aporte térmico é o de promover o revenimento da microestrutura (BHADESHIA, 2006). Nesta região, é possível observar a mudança de morfologia das bandas perlíticas, as quais vão se degradando pela influência térmica e dão origem a perlita degenerada.

Vale ressaltar que, dependendo do processo de soldagem utilizado, a ZTA é tão estreita que a sua identificação é bastante difícil, especialmente quanto à visualização no microscópio ótico, como no caso do processo de soldagem por feixe de elétrons. Neste caso, técnicas de microscopia mais avançadas precisam ser utilizadas.

Outra observação importante é o fato de que a ZF e a ZTA podem apresentar microestruturas bastante heterogêneas, ou seja, diversas fases e microconstituintes podem coexistir, uma vez que existe um perfil de temperatura associado a cada tipo de soldagem, a cada tipo de material e a cada aporte térmico. 


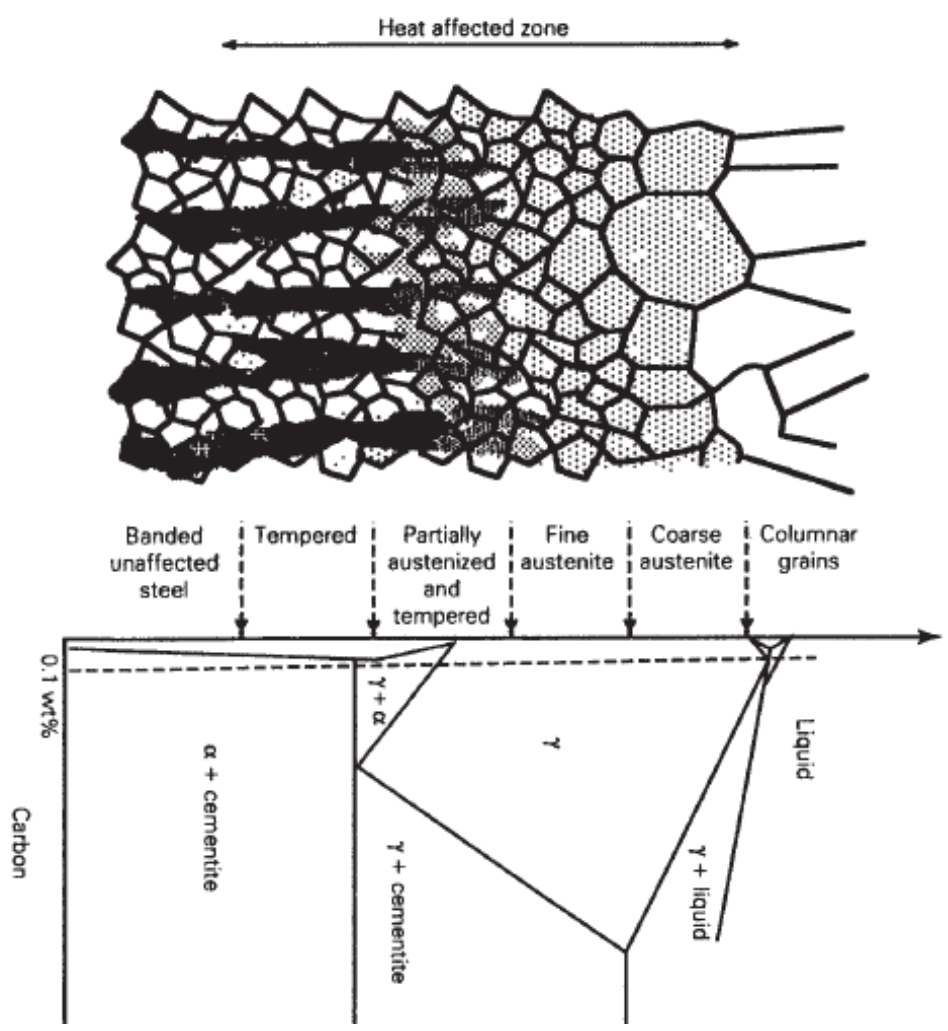

Figura 8. Ilustração esquemática da variação microestrutural esperada na ZTA de um aço carbono soldado (BHADESHIA, 2006).

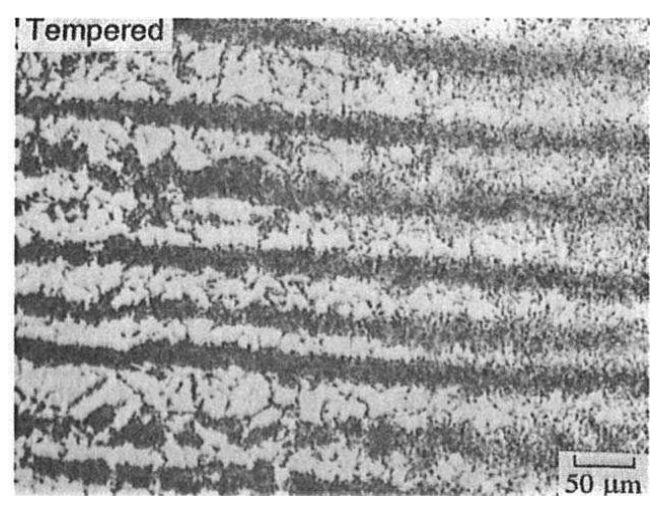

(a)

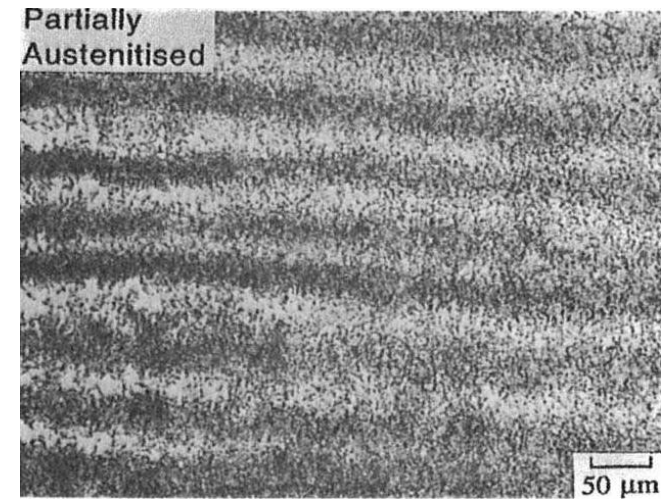

(b)

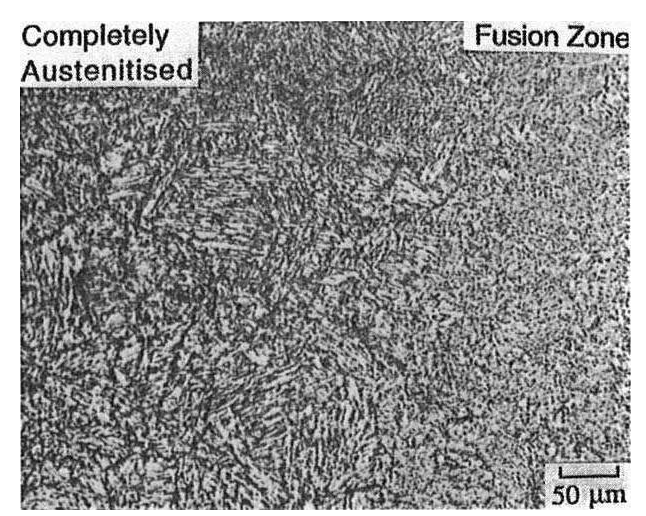

(c)

Figura 9. Microestruturas das diferentes regiões da ZTA. (a) região revenida; (b) região parcialmente transformada e (c) região completamente austenitizada (BHADESHIA, 2006). 


\section{MATERIAIS E MÉTODOS}

\subsection{MATERIAIS}

O material utilizado neste estudo foi uma chapa de aço API 5L X65 produzida via laminação controlada, fornecida gentilmente pela Usiminas (ex-COSIPA). As dimensões desta chapa são 17,48 x 100 x 200 mm. A composição química e algumas propriedades mecânicas do material em estudo são apresentadas nas Tabelas 1, 2 e 3.

Tabela 1. Composição química do aço API X65 (valores \% em peso) (USIMINAS).

\begin{tabular}{ccccccccccccc}
$\mathbf{C}$ & $\mathbf{M n}$ & $\mathbf{P}$ & $\mathbf{S}$ & $\mathbf{S i}$ & $\mathbf{A l}$ & $\mathbf{N b}$ & $\mathbf{V}$ & $\mathbf{T i}$ & $\mathbf{C r}$ & $\mathbf{N i}$ & $\mathbf{N}$ & $\mathbf{C E}$ \\
\hline 0,09 & 1,46 & 0,016 & 0,003 & 0,24 & 0,03 & 0,04 & 0,04 & 0,02 & 0,03 & 0,01 & 0,006 & 0,35 \\
\hline
\end{tabular}

Tabela 2. Propriedades mecânicas do aço API 5L X65 obtidas por ensaios de tração ( USIMINAS)

\begin{tabular}{cccccc}
\hline Ensaio & $\begin{array}{c}\text { Temperatura } \\
\text { de ensaio }\left({ }^{\circ} \mathrm{C}\right)\end{array}$ & $\begin{array}{c}\text { Limite de } \\
\text { escoamento } \\
(\mathrm{MPa})\end{array}$ & $\begin{array}{c}\text { Limite de } \\
\text { resistência } \\
(\mathrm{MPa})\end{array}$ & $\begin{array}{c}\text { Alongamento } \\
(\%)\end{array}$ & Razão elástica \\
\hline $\begin{array}{c}\text { Tração } \\
\text { (transversal) }\end{array}$ & 23 & 526 & 613 & 37,8 & 0,86 \\
\hline
\end{tabular}

Tabela 3. Propriedades mecânicas do aço API 5L X65 obtidas por ensaios Charpy (USIMINAS)

\begin{tabular}{|c|c|c|c|c|}
\hline Ensaio & $\begin{array}{c}\text { Temperatura } \\
\text { de ensaio }\left({ }^{\circ} \mathrm{C}\right)\end{array}$ & $\begin{array}{l}\text { Profundidade } \\
\text { de entalhe } \\
\text { (mm) }\end{array}$ & $\begin{array}{c}\text { Energia } \\
\text { absorvida }(\mathrm{J})\end{array}$ & Área dúctil (\%) \\
\hline \multirow{2}{*}{$\begin{array}{c}\text { Impacto Charpy } \\
\text { (transversal) }\end{array}$} & \multirow{2}{*}{0} & \multirow[t]{2}{*}{ 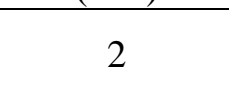 } & $\begin{array}{lll}134 & 161 & 157 \\
\end{array}$ & \multirow{2}{*}{100} \\
\hline & & & Média: 150,7 & \\
\hline
\end{tabular}

\subsection{MÉTODOS}

\subsubsection{Soldagem por feixe de elétrons}

A chapa foi soldada por feixe de elétrons pela empresa INB (Indústrias Nucleares do Brasil S.A.). A soldagem foi realizada em alto-vácuo $\left(5 \times 10^{-4}\right.$ mbar $)$, com tensão de aceleração constante de $60 \mathrm{kV}$, corrente de soldagem de $70 \mathrm{~mA}$ e cinco velocidades distintas de 2, 6, 10, 14 e $18 \mathrm{~mm} / \mathrm{s}$ (Figura 10). A soldagem da chapa foi realizada sem metal de adição. As Figuras 11 e 12 apresentam a máquina de soldagem instalada nas dependências da INB e o detalhe da câmara de soldagem. 


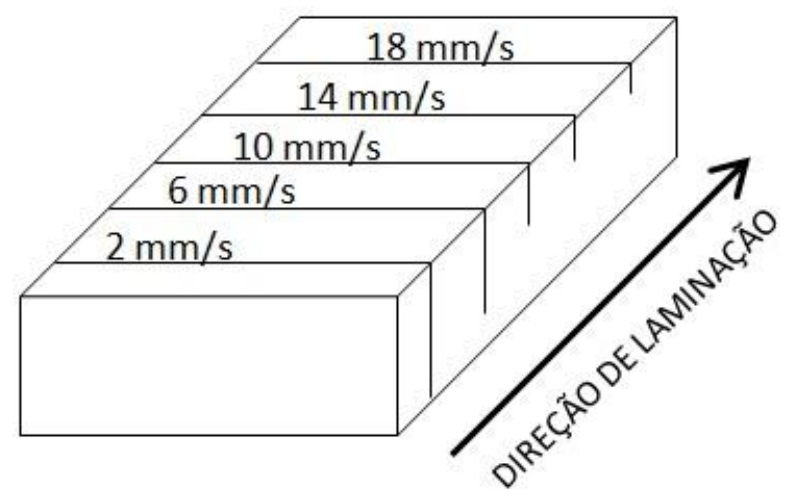

Dimensão da peça : $17,48 \times 100 \times 200 \mathrm{~mm}$

Figura 10. Peça soldada com dimensão, velocidade dos cordões de solda e sentido de laminação perpendicular à soldagem.

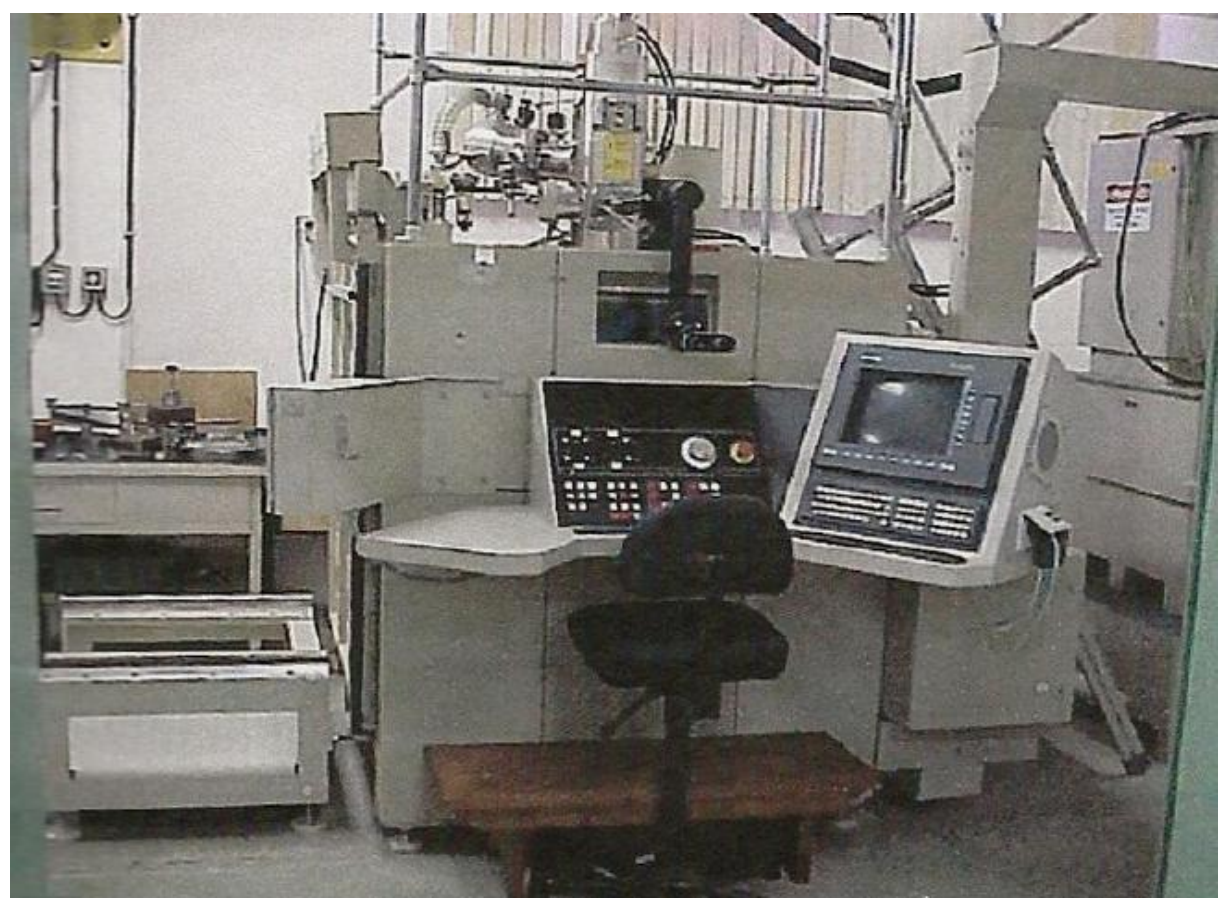

Figura 11 - Máquina de solda por feixe de elétrons instalada na INB. (SÁ, 2005). 


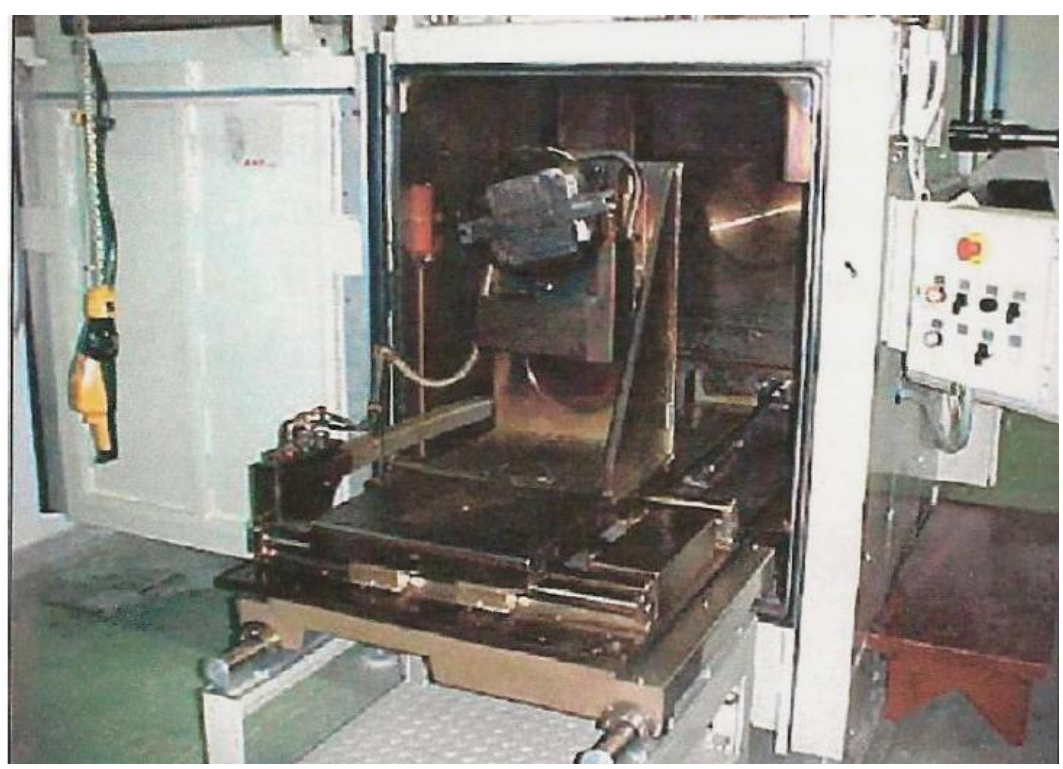

Figura 12 - Câmara de soldagem por feixe de elétrons e detalhe da mesa X-Y-Z (SÁ, 2005).

\subsubsection{Dilatometria}

Ensaios de dilatometria no aço na condição como-recebido foram realizados para determinar as temperaturas de transformação de aquecimento e resfriamento da região intercrítica do aço em estudo. Foram retiradas amostras cilíndricas com dimensão de $\phi 12$ mm x 2 mm no sentido paralelo à direção de laminação. Para este ensaio, utilizou-se um dilatômetro de têmpera, conforme as condições fornecidas na Tabela 4. Os ensaios foram realizados na Fundação Centro Tecnológico de Minas Gerais - CETEC. O aquecimento foi realizado em baixo vácuo e o resfriamento foi feito ao ar.

Tabela 4. Condições de ensaio de dilatometria do aço como recebido.

\begin{tabular}{|c|c|c|c|}
\hline $\begin{array}{c}\text { Taxa de } \\
\text { aquecimento }\end{array}$ & $\begin{array}{l}\text { Temperatura } \\
\text { máxima }\end{array}$ & Tempo na $T_{\text {máx }}$ & $\begin{array}{c}\text { Taxa de } \\
\text { resfriamento }\end{array}$ \\
\hline $1^{\circ} \mathrm{C} / \mathrm{s}$ & $950^{\circ} \mathrm{C}$ & $1 \mathrm{~min}$ & $10^{\circ} \mathrm{C} / \mathrm{s}$ \\
\hline $5^{\circ} \mathrm{C} / \mathrm{s}$ & $950^{\circ} \mathrm{C}$ & $1 \mathrm{~min}$ & $10^{\circ} \mathrm{C} / \mathrm{s}$ \\
\hline $\mathbf{3 0}^{\circ} \mathrm{C} / \mathrm{s}$ & $950^{\circ} \mathrm{C}$ & $1 \mathrm{~min}$ & $10^{\circ} \mathrm{C} / \mathrm{s}$ \\
\hline
\end{tabular}




\subsubsection{Preparação metalográfica das amostras}

A preparação metalográfica teve início com os cortes com disco diamantado utilizando a máquina ISOMET 1000-Buehler. Após o corte, as amostras foram embutidas a frio com resina tipo baquelite. As amostras foram lixadas com lixas de $\mathrm{SiC}$ de granas 180, $320,500,800,1200$ e 2400. As amostras foram polidas manualmente utilizando uma suspensão à base de sílica coloidal. Diferentes ataques químicos foram testados para revelar a microestrutura das regiões soldadas com os cinco diferentes aportes térmicos. Os ataques utilizados são descritos abaixo.

- Nital 2\%: Utilizado para avaliação de aspectos metalúrgicos, como tamanho de grão, fases formadas e avaliação da integridade da junta soldada.

- $\quad$ Klemm 1 (VANDER VOORT, 1984): Utilizado para revelar os constituintes M-A nas amostras soldadas. Evidencia a fase ferrita (cor azul) e os constituintes M-A (cor branca).

- LePera: Utilizado para revelar a bainita nas amostras soldadas. Este ataque químico possibilita a revelação da estrutura bainítica por meio da coloração "preta".

\subsubsection{Microscopia óptica}

As amostras foram analisadas via microscopia óptica em um microscópio LEICA DM IRM, com câmera digital SCC 131 e analisador de imagens QWIN. As imagens foram obtidas com ampliações de 500 e 1000 vezes.

\subsubsection{Microscopia eletrônica de varredura (MEV)}

Imagens com maiores ampliações foram obtidas com o auxílio da técnica de microscopia eletrônica de varredura nos modos de elétrons secundários e retroespalhados. Para isto, utilizou um microscópio LEO 1450-VP com filamento de tungstênio e tensão de aceleração de $20 \mathrm{kV}$ instalado no DEMAR-EEL-USP para menores ampliações e outro JEOL 6500-F com canhão de emissão de campo e tensão de aceleração de $20 \mathrm{kV}$ instalado no MPIE (Alemanha) para a obtenção de imagens com maior resolução. 


\subsubsection{Microdureza Vickers}

As medidas de microdureza Vickers foram realizadas na seção transversal das amostras para determinar o perfil de dureza nas diferentes regiões da junta. Utilizou-se um microdurômetro Micromet 2004-Buehler com carga de 300 g, segundo a ASTM E384-10, (2010). As medidas foram realizadas na posição horizontal em três pontos principais: superfície, centro e raiz como está mostrado na Figura 13.

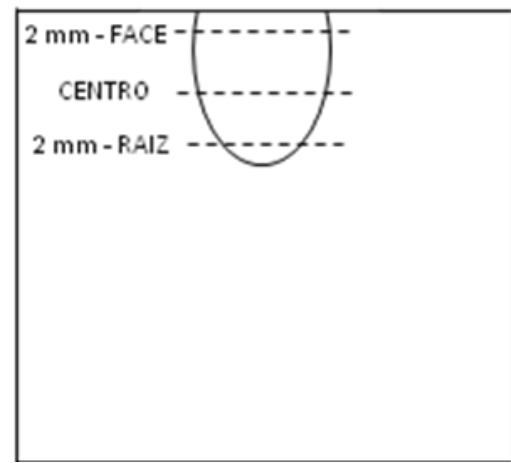

Figura 13. Representação esquemática das medidas de microdureza Vickers ao longo das amostras.

\subsubsection{Difração de raios $X$}

Para determinação da eventual presença de austenita retida nas amostras, utilizou-se a técnica de difração de raios $X$ na região do cordão de solda. Para esta análise, utilizou-se um difratômetro de raios X SHIMADZU, modelo XRD 6000, com tensão de aceleração de $50 \mathrm{kV}$, corrente de $30 \mathrm{~mA}$, passo angular de $0,02^{\circ}$ com tempo de aquisição de $5 \mathrm{~s}$ e ângulo $2 \theta$ no intervalo $15-30^{\circ}$, justamente na região do pico mais intenso da austenita. Como se trata de uma amostra de aço, sujeita à fluorescência, o tubo usado foi de Mo (radiação $\mathrm{MoK} \alpha)$ com um filtro de $\mathrm{Zr}$ colocado junto às fendas de entrada para filtrar as radiações indesejáveis K- $\beta$ e branca. 


\section{RESULTADOS E DISCUSSÃO}

\subsection{MEDIDAS DE DILATOMETRIA}

As linhas de transformação e as temperaturas da região intercrítica do aço em estudo foram levantadas para as condições de taxas de aquecimento de $1^{\circ} \mathrm{C} / \mathrm{s}, 5^{\circ} \mathrm{C} / \mathrm{s}$ e $30^{\circ} \mathrm{C} / \mathrm{s} \mathrm{com}$ uma taxa de resfriamento constante de $10^{\circ} \mathrm{C} / \mathrm{s}$. As Figuras 14,15 e 16 apresentam os resultados obtidos a partir dos ensaios de dilatometria.

Pode-se observar que para todas as taxas de aquecimento utilizadas neste ensaio, as temperaturas críticas $\left(\mathrm{Ac}_{1}, \mathrm{Ac}_{3}, \mathrm{Ar}_{1}\right.$ e $\left.\mathrm{Ar}_{3}\right)$ são próximas, sugerindo uma baixa dependência com a taxa de aquecimento. Quando se compara os valores das temperaturas $\mathrm{Ac}_{1}, \mathrm{Ac}_{3}, \mathrm{Ar}_{1}$ e $\mathrm{Ar}_{3}$ encontradas para uma liga de $\mathrm{Fe}-\mathrm{C}$ com carbono próximo de 0,09\% com um aço carbono comum, observa-se que as encontradas neste estudo são menores. Portanto, este efeito está associado aos microligantes $\mathrm{Nb}, \mathrm{V}$, Ti e também ao Mn (COSTA E SILVA, 2006).

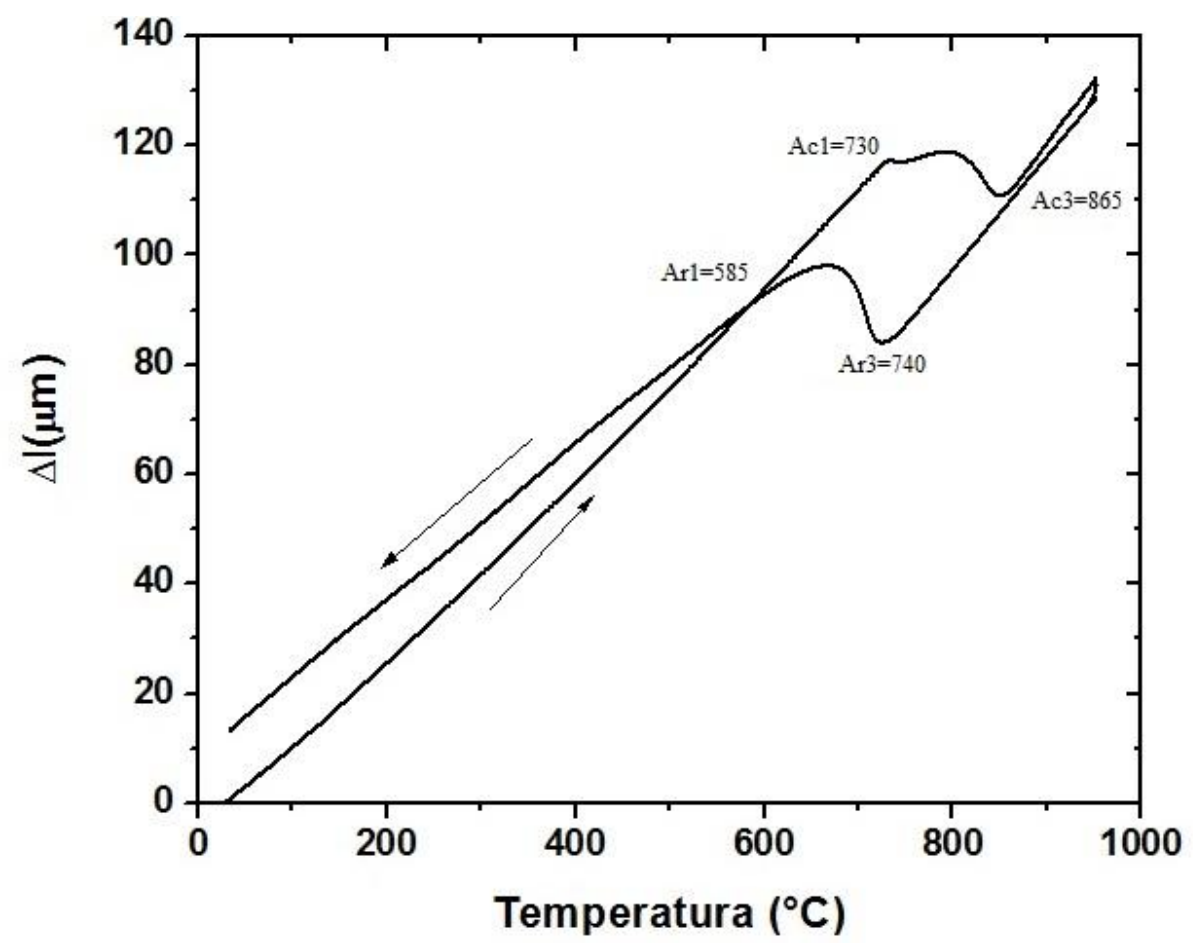

Figura 14. Curva dilatométrica do aço API 5L X65 para uma taxa de aquecimento de $1{ }^{\circ} \mathrm{C} / \mathrm{s}$. 


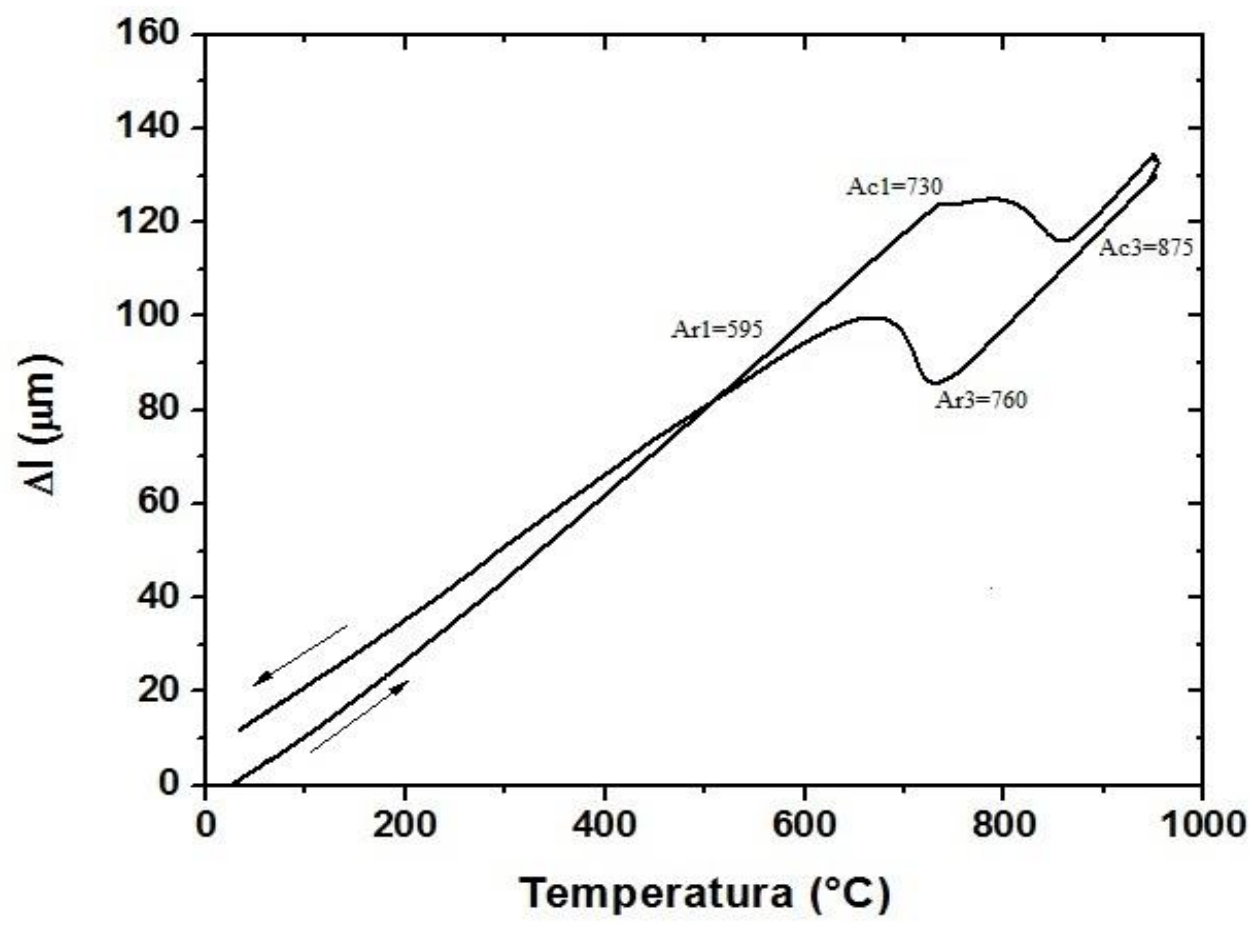

Figura 15. Curva dilatométrica do aço API 5L X65 para uma taxa de aquecimento de $5^{\circ} \mathrm{C} / \mathrm{s}$.

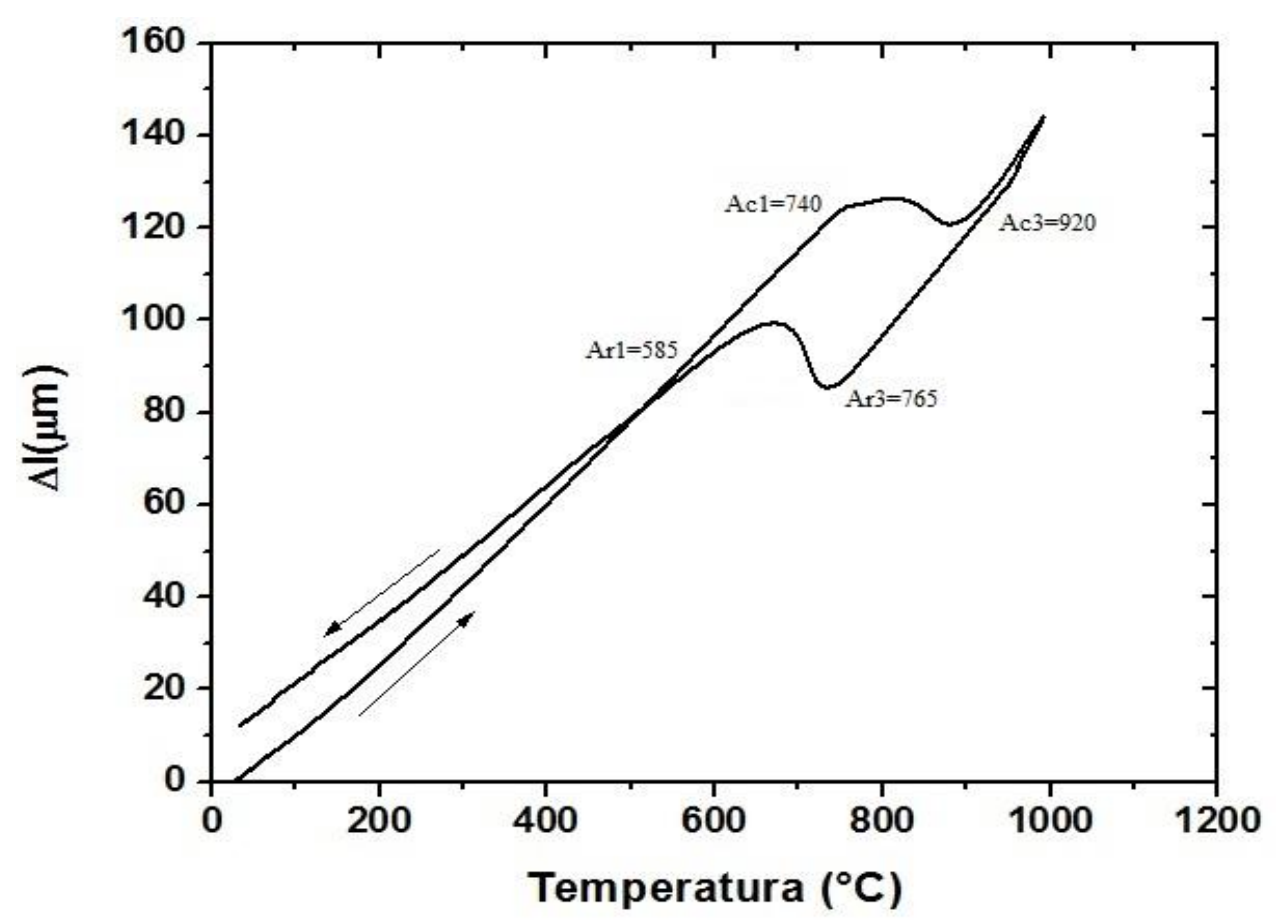

Figura 16. Curva dilatométrica do aço API 5L X65 para uma taxa de aquecimento de $30^{\circ} \mathrm{C} / \mathrm{s}$. 


\subsection{FRAÇÃO VOLUMÉTRICA DAS FASES E DOS CONSTITUINTES MICROESTRUTURAIS NO METAL-BASE}

Para a determinação da fração volumétrica da fase ferrita e do constituinte perlita do metal-base, utilizou-se a norma ASTM E562-08 (2008). Com o auxílio do programa Image $J$, gerou-se uma grade de 80 pontos em 20 imagens para a quantificação (Figura 17). A Tabela 5 fornece as frações volumétricas encontradas de ferrita e perlita neste aço. Valores semelhantes foram reportados por Sant'anna (2006) num estudo envolvendo o mesmo aço API 5L X65.

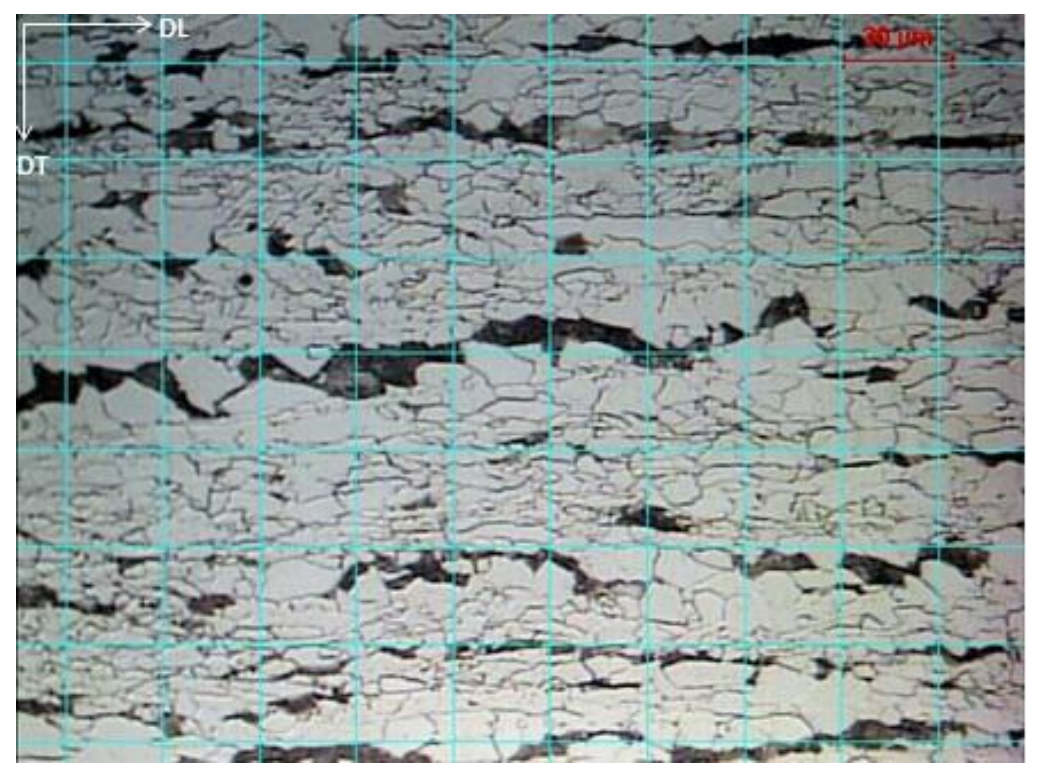

Figura 17. Grade de pontos ilustrativa para quantificação de fases da seção transversal do aço API $5 \mathrm{~L} \times 65$.

Tabela 5. Fração volumétrica de ferrita e perlita no MB.

\begin{tabular}{c|cc}
\hline \multirow{2}{*}{ Média } & Ferrita (\%) & Perlita (\%) \\
\cline { 2 - 3 } & $80,19 \pm 2,54$ & $19,81 \pm 2,54^{*}$ \\
\hline
\end{tabular}

\footnotetext{
* Determinada por diferença.
} 


\subsection{PROFUNDIDADE X LARGURA DAS AMOSTRAS}

Os valores da profundidade de penetração e da largura do cordão de solda foram determinados a partir das respectivas macrografias das cinco soldas. Os resultados são mostrados na Tabela 6. A partir destes resultados, é possível observar que quanto maior a velocidade de soldagem menor será a penetração do cordão de solda, o mesmo ocorre para a largura. A relação penetração versus largura varia com o aporte térmico. As medidas foram realizadas com o auxílio de um paquímetro digital.

Tabela 6. Relação penetração versus largura dos cordões de solda das cinco amostras em estudo.

\begin{tabular}{ccc}
\hline Amostras & Penetração $(\mathbf{m m})$ & Largura $(\mathbf{m m})$ \\
\hline $\mathbf{2} \mathbf{~ m m} / \mathbf{s}$ & 17,5 & 5,2 \\
\hline $\mathbf{6 ~ m m} / \mathbf{s}$ & 11,2 & 4,6 \\
\hline $\mathbf{1 0 ~} \mathbf{~ m} / \mathbf{s}$ & 7,4 & 3,6 \\
\hline $\mathbf{1 4} \mathbf{~ m m} / \mathbf{s}$ & 6,0 & 3,2 \\
\hline $\mathbf{1 8 ~} \mathbf{~ m} / \mathbf{s}$ & 5,6 & 2,5 \\
\hline
\end{tabular}

\subsection{SEGREGAÇÃO CENTRAL NA CHAPA LAMINADA}

Análises químicas via microscopia eletrônica de varredura (EDS) foram realizadas nesta mesma chapa num trabalho anterior para quantificar os teores dos elementos que segregam durante o lingotamento contínuo dos aços (PINTO, 2011). A Figura 18 apresenta as micrografias referentes à linha de segregação central da chapa em estudo. A segregação central das chapas deste aço também foi observada por Ogata (2009). Nos aços ARBL, é muito comum a segregação de Mn e dos elementos microligantes com a correspondente formação de carbonetos que elevam localmente a dureza local do material, diminuindo a tenacidade à fratura. 


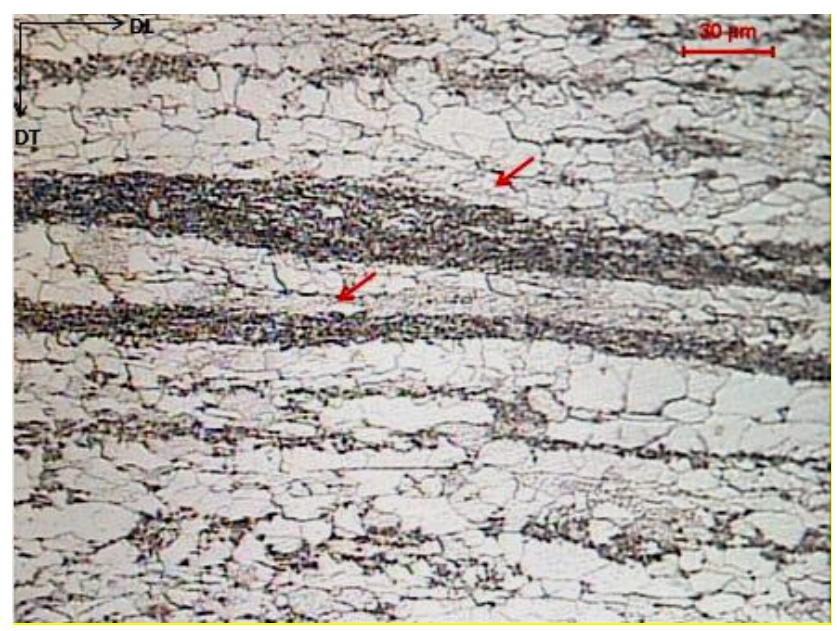

MO, Nital 2\%

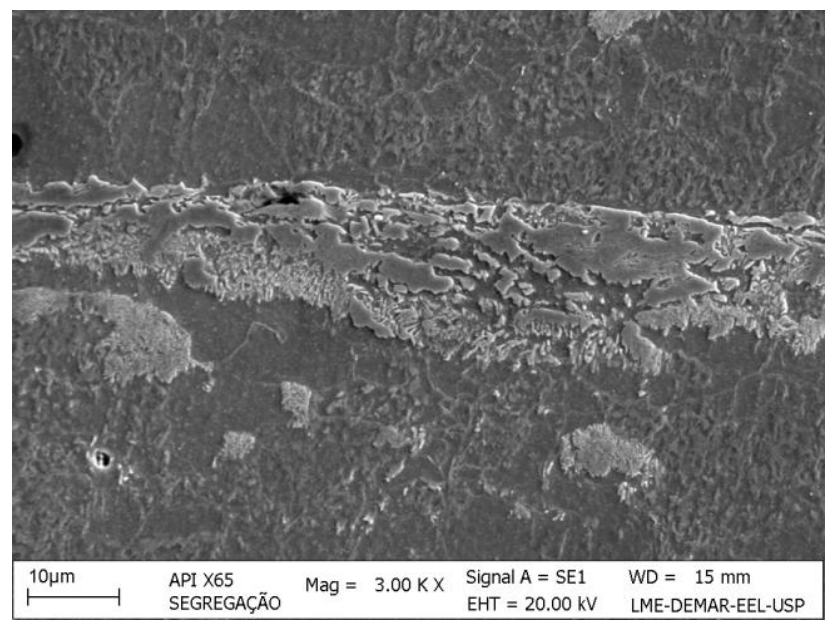

MEV, Nital $2 \%$

Figura 18. Micrografias via microscopia óptica e microscopia eletrônica de varredura apresentando linha de segregação central na seção transversal da chapa.

\subsection{CARACTERIZAÇÃO MICROESTRUTURAL DA REGIÃO SOLDADA}

\subsubsection{Microscopia óptica}

As três regiões da junta soldada MB, ZTA e ZF foram caracterizadas pela técnica de microscopia óptica com ataques químicos diferentes. As Figuras 19-23 apresentam as microestruturas destas três regiões das juntas soldadas com velocidades de $2 \mathrm{~mm} / \mathrm{s}$, 6 $\mathrm{mm} / \mathrm{s}, 10 \mathrm{~mm} / \mathrm{s}, 14 \mathrm{~mm} / \mathrm{s}$ e $18 \mathrm{~mm} / \mathrm{s}$, respectivamente. 


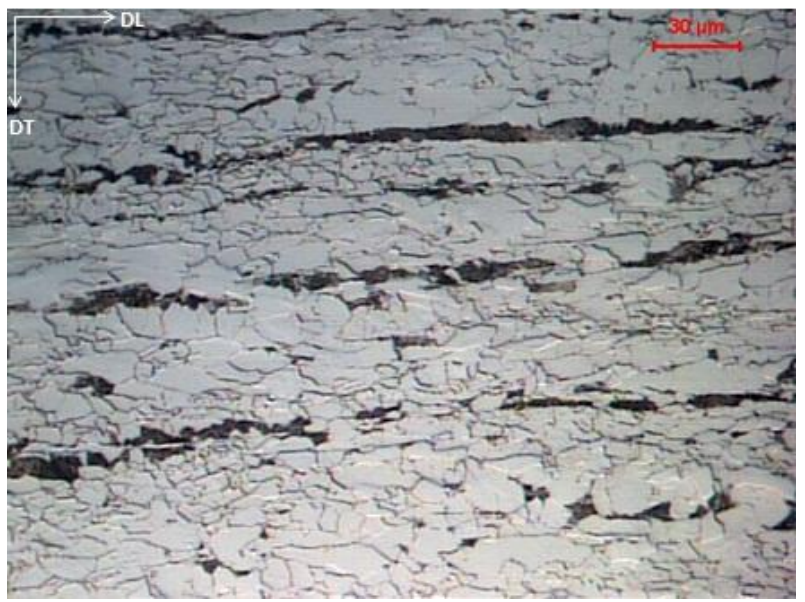

(a)
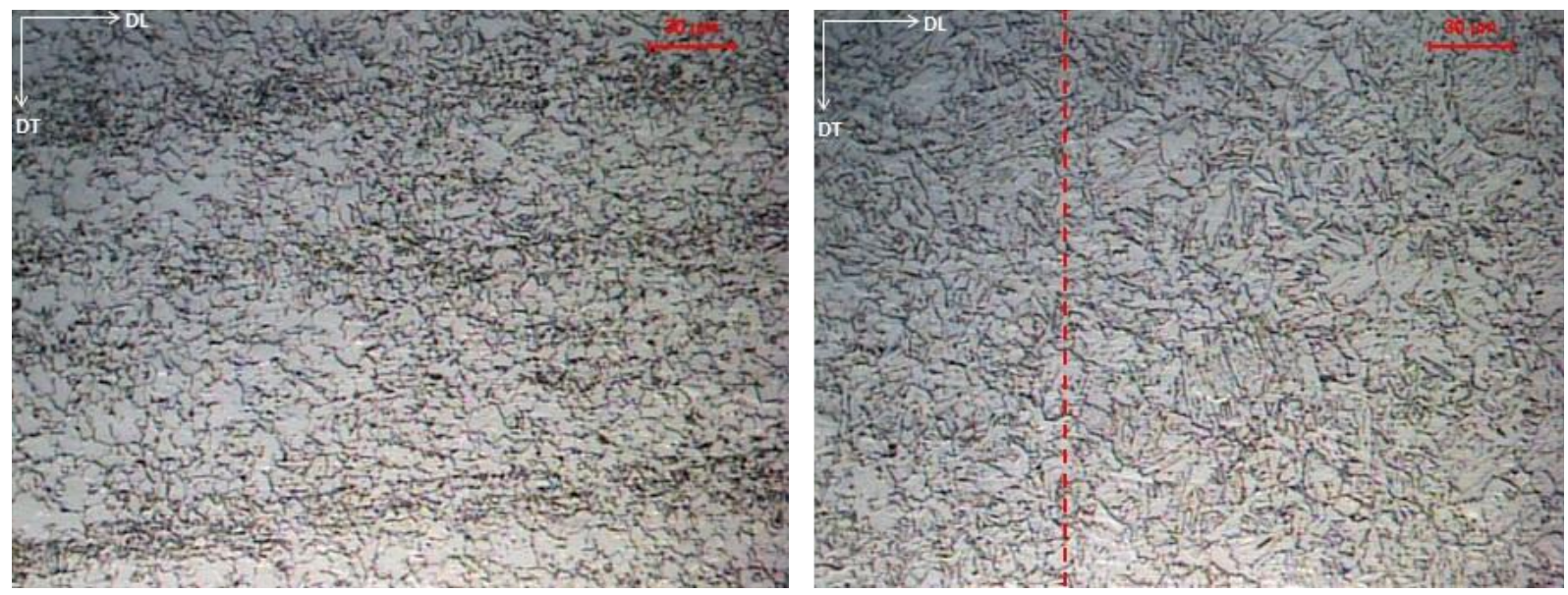

(b)

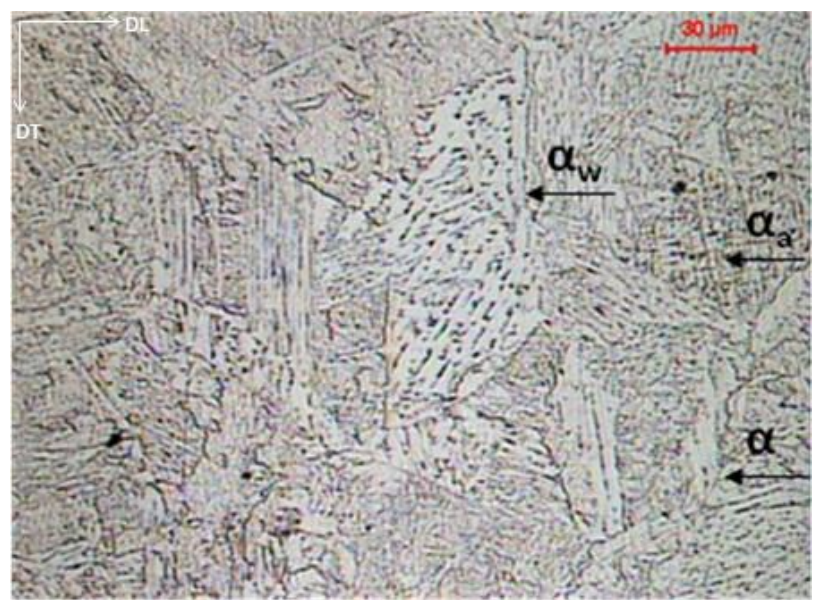

(c)

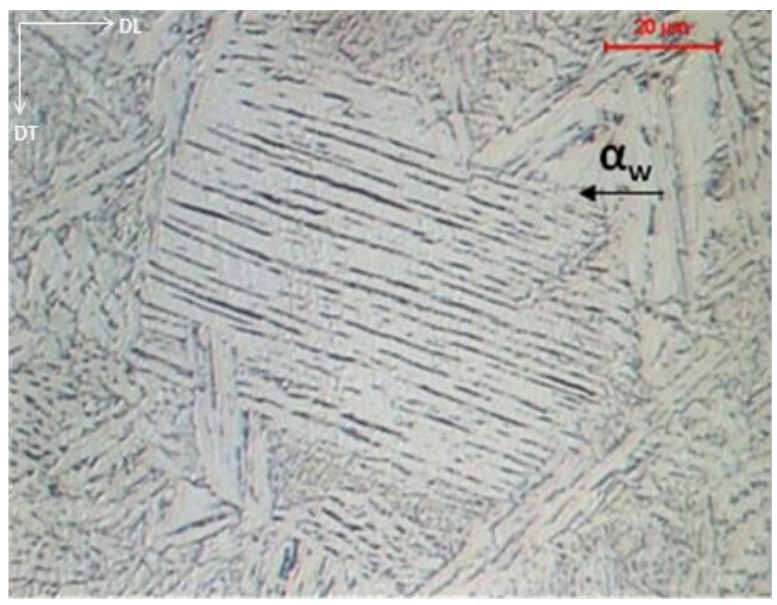

(d)

Figura 19. Microestruturas via microscopia óptica da junta soldada com velocidade de $2 \mathrm{~mm} / \mathrm{s}$. (a) MB; (b) ZTA e interface ZTA/ZF; (c) ZF e (d) ZF, destaque para a possível microestrutura bainita. Ataque: Nital 2\%. 


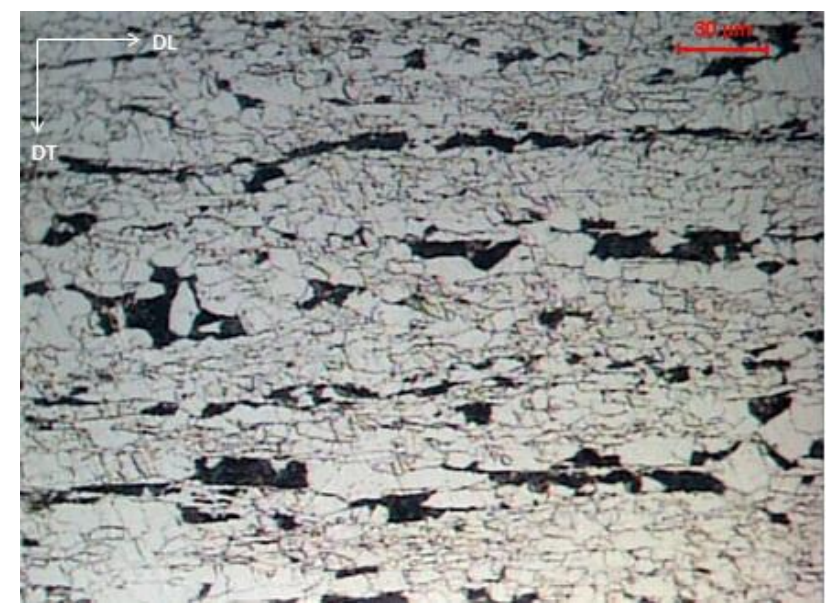

(a)
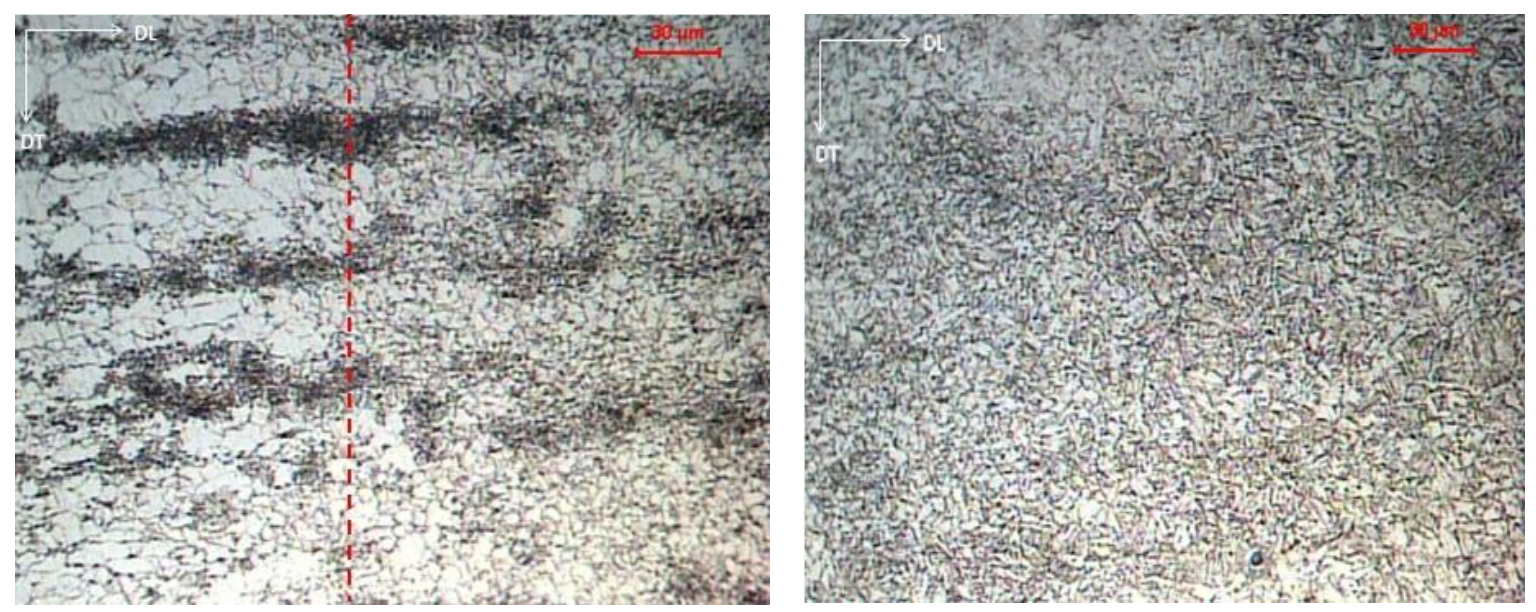

(b)

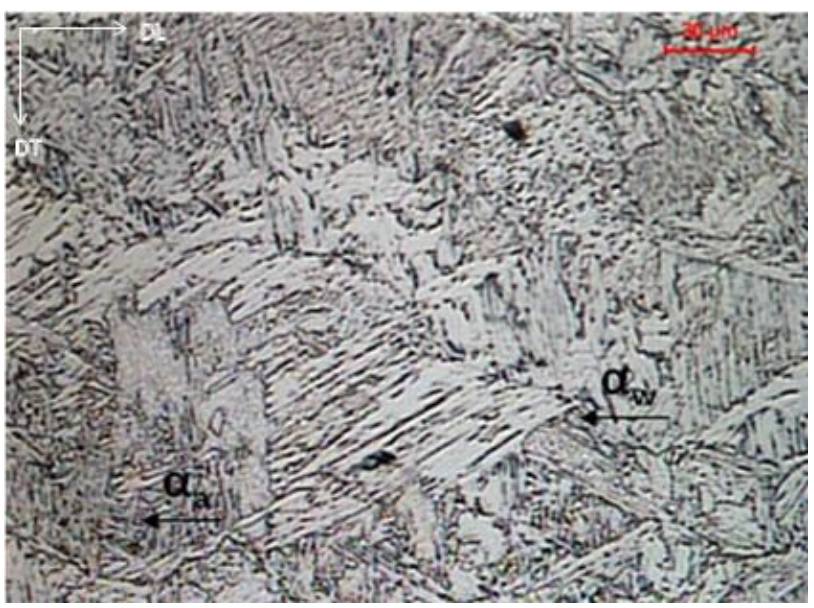

(c)

Figura 20. Microestruturas via microscopia óptica da junta soldada com velocidade de $6 \mathrm{~mm} / \mathrm{s}$. (a) MB; (b) interface MB / ZTA e ZTA e (c) ZF. Ataque: Nital 2\%. 


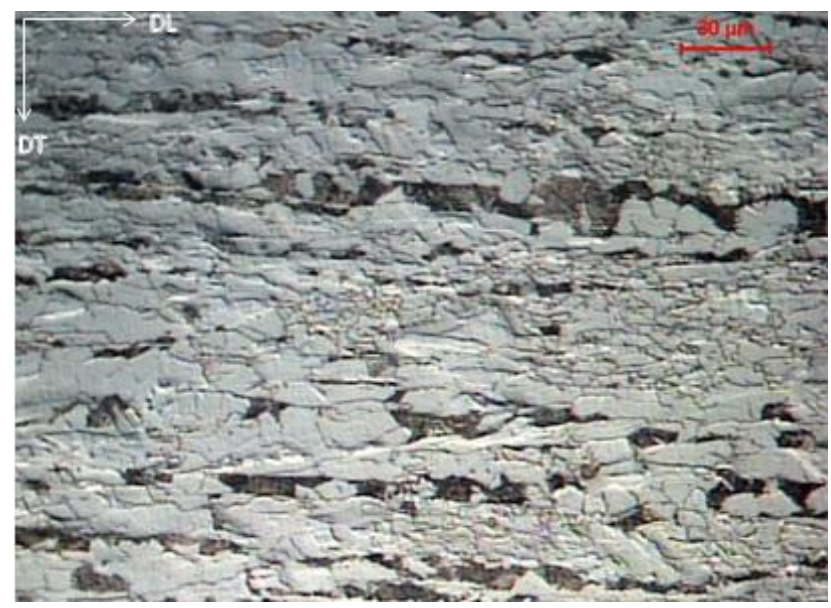

(a)
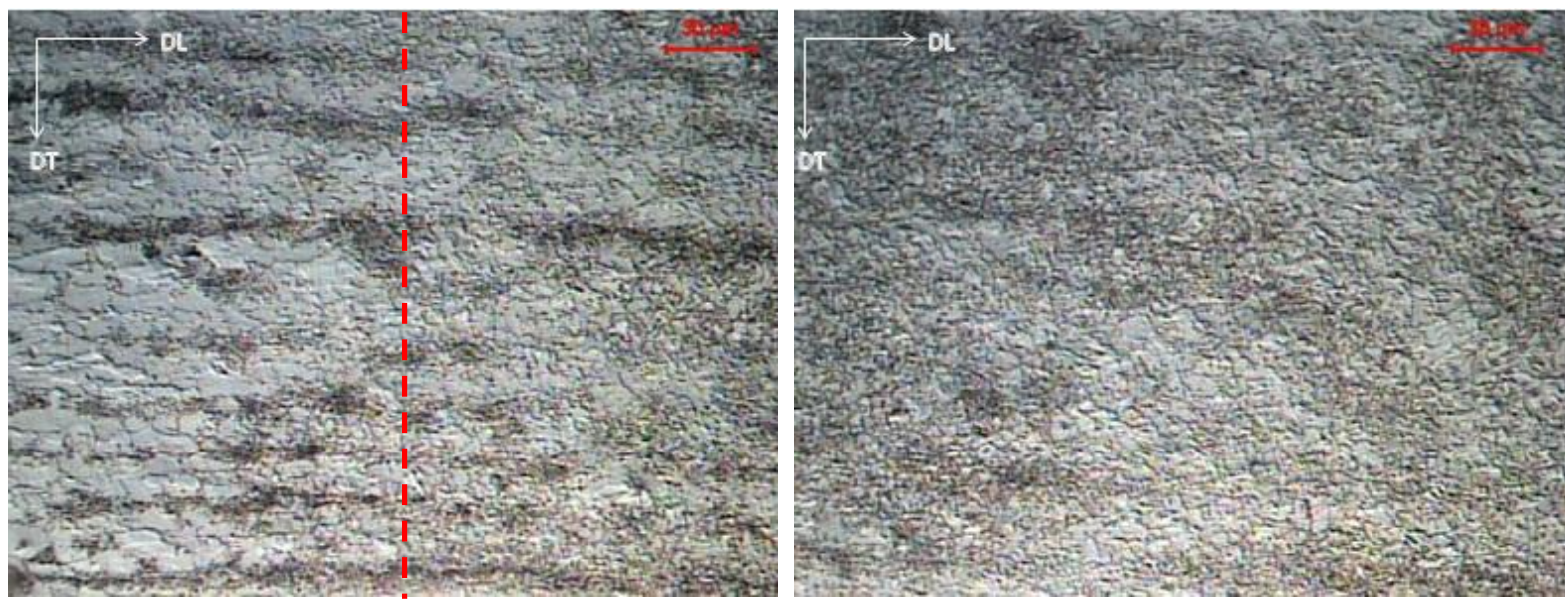

(b)

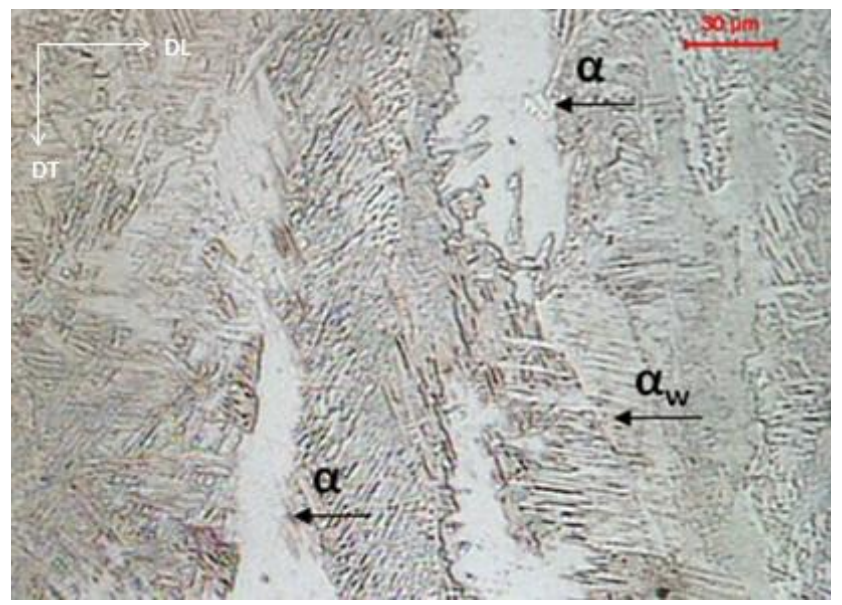

(c)

Figura 21. Microestruturas via microscopia óptica da junta soldada com velocidade de $10 \mathrm{~mm} / \mathrm{s}$ (a) MB; (b) interface MB / ZTA e ZTA e (c) ZF. Ataque: Nital 2\%. 


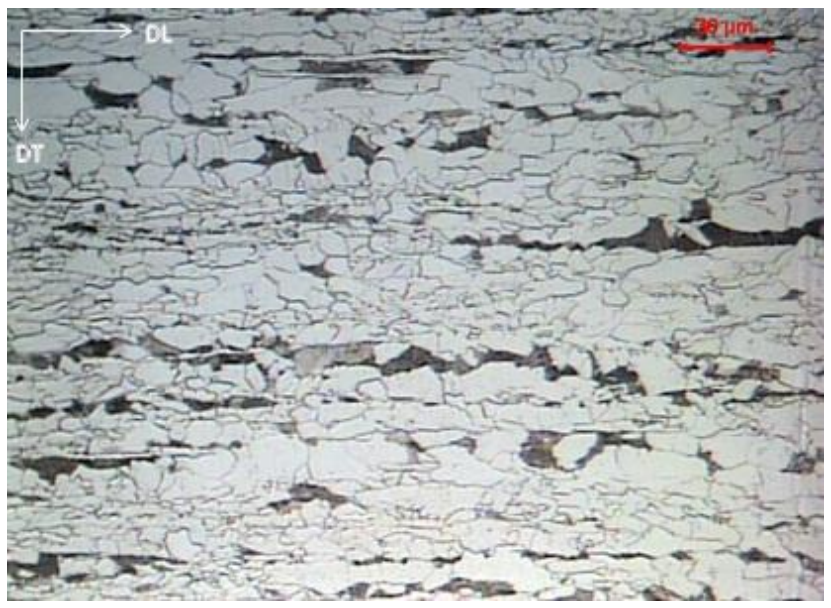

(a)

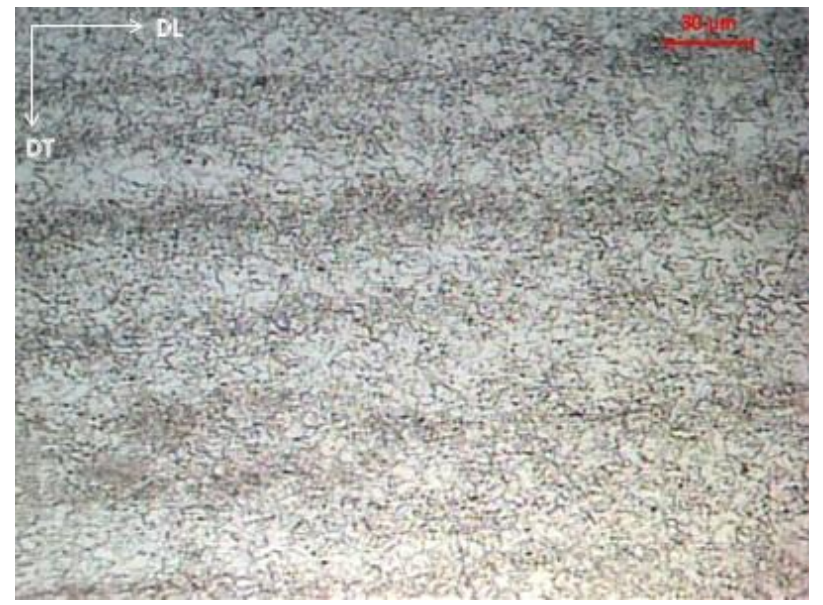

(b)

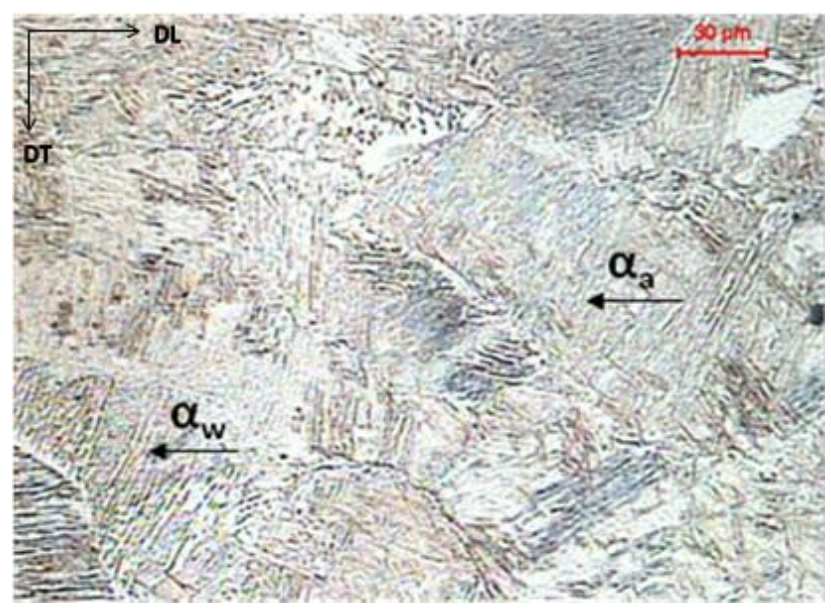

(c)

Figura 22. Microestruturas via microscopia óptica da junta soldada com velocidade de $14 \mathrm{~mm} / \mathrm{s}$. (a) MB; (b) ZTA e (c) ZF. Aumento: 500x. Ataque: Nital 2\%. 


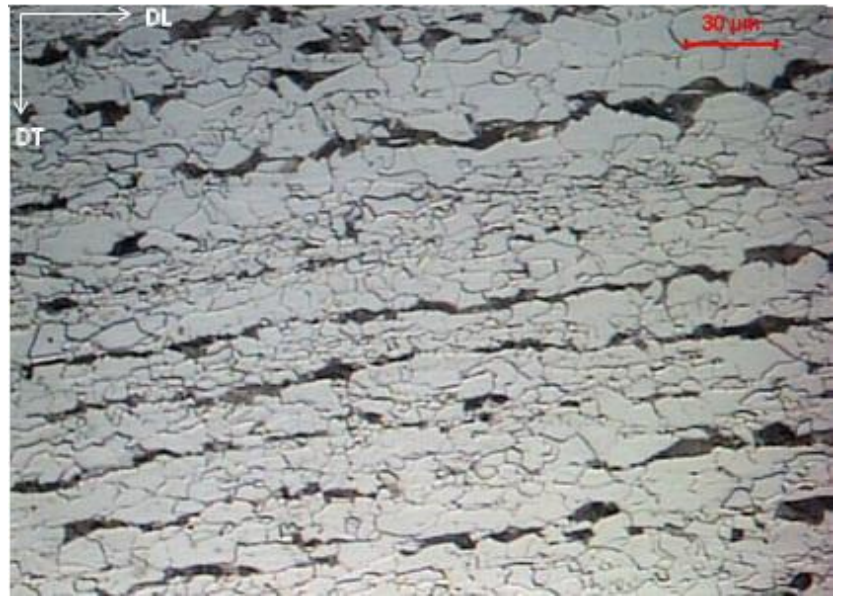

(a)

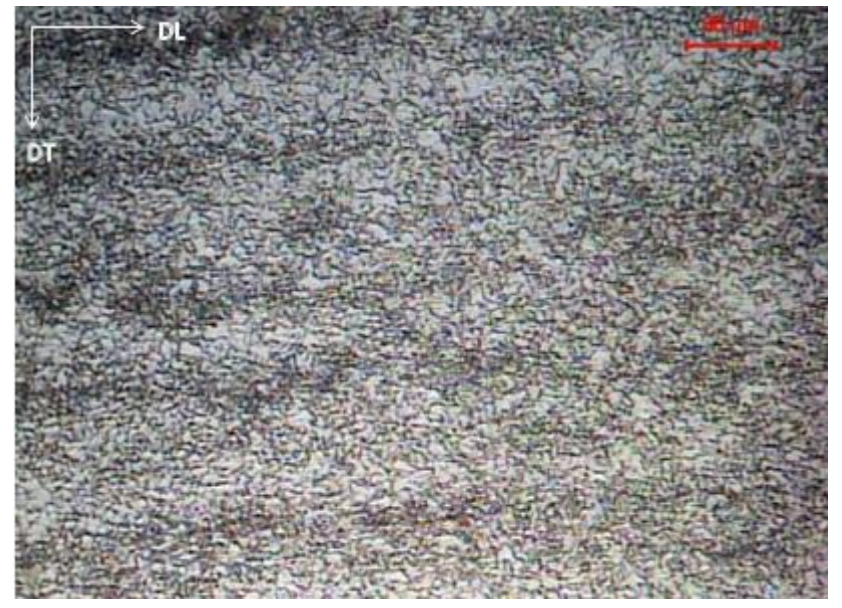

(b)

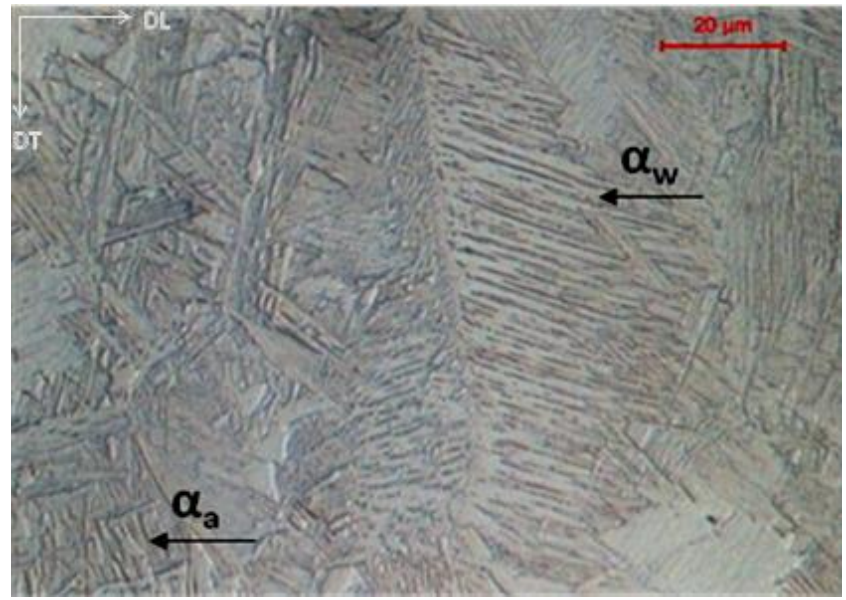

(c)

Figura 23. Microestruturas obtidas por microscopia óptica da junta soldada com velocidade de 18 mm/s. (a) MB; (b) ZTA e (c) ZF. Aumento: 500x. Ataque: Nital 2\%. 
As Figuras 19, 20, 21, 22 e 23 (a) apresentam a microestrutura do MB, composta pela ferrita (cor clara) e pelo constituinte perlita (cor escura), ambas alinhadas no sentido de laminação da chapa. Esta microestrutura é a comumente encontrada nos aços ARBL, com baixo teor de carbono.

As Figuras 19, 20, 21, 22 e 23 (b) apresentam as microestruturas da ZTA. É possível observar a presença de bandas perlíticas degeneradas. Muito provavelmente, a ZTA atinge temperaturas altas o suficiente para causar a degeneração da estrutura perlítica (FURUHARA, 2007). Observa-se um refinamento do grão quando comparado com os grãos do MB. Isso se deve ao fato da transformação $\gamma \rightarrow \alpha$. Devido à elevada densidade de potência na soldagem por feixe de elétrons, a ZTA se apresenta bastante estreita e refinada. Sendo assim, para as maiores velocidades de soldagem utilizadas neste trabalho, $14 \mathrm{~mm} / \mathrm{s}$ e $18 \mathrm{~mm} / \mathrm{s}$ a ZTA é tão estreita que não é possível identificá-la.

As Figuras 19, 20, 21, 22 e 23 (c) apresentam as microestruturas típicas encontradas na ZF. É possível verificar a presença de ferrita alotriomórfica, a primeira fase a se formar quando este aço é resfriado; a ferrita acicular cuja estrutura consiste de um arranjo de placas de ferrita em diferentes direções no interior do outrora grão austenítico (YOUNG, 2008), a qual nucleia em inclusões não-metálicas (BABU, 2004; BHADESHIA, 2006); a ferrita de Widmanstätten cuja microestrutura é formada por placas alongadas que nucleiam no contorno de grão austenítico ou a partir de uma fase que já finalizou o seu crescimento como a ferrita alotriomórfica.

Pelo fato da soldagem por feixe de elétrons ser realizada em alto vácuo e sem o uso de metal de adição, a ferrita acicular foi pouco evidenciada na microestrutura. Logo, a baixa fração evidenciada desta fase está ligada a presença de poucas inclusões nãometálicas provenientes do próprio aço e que não puderam ser completamente solubilizadas durante a fusão. 
A Figura 19 (d) apresenta uma ampliação da possível formação da bainita, a qual está caracterizada por placas alternadas de ferrita e cementita. Vale lembrar que esta imagem está com ampliação de 1000 x.

O uso do reagente Klemm 1 revela detalhes importantes que não são visualizados nas amostras atacadas com o Nital $2 \%$. Este ataque químico permite avaliar a presença do constituinte M-A em aços ARBL (VANDER VOORT, 1984; SHUI, 1988). Foi possível verificar a presença destes constituintes no MB, ao longo da linha de segregação da chapa, rica em elementos austenitizantes como o Mn, e também na ZTA com uma maior distribuição.

Pelo fato de todas as amostras apresentarem a mesma distribuição destes constituintes, apenas as imagens referentes à amostra soldada com velocidade de $10 \mathrm{~mm} / \mathrm{s}$ são apresentadas na Figura 24. 


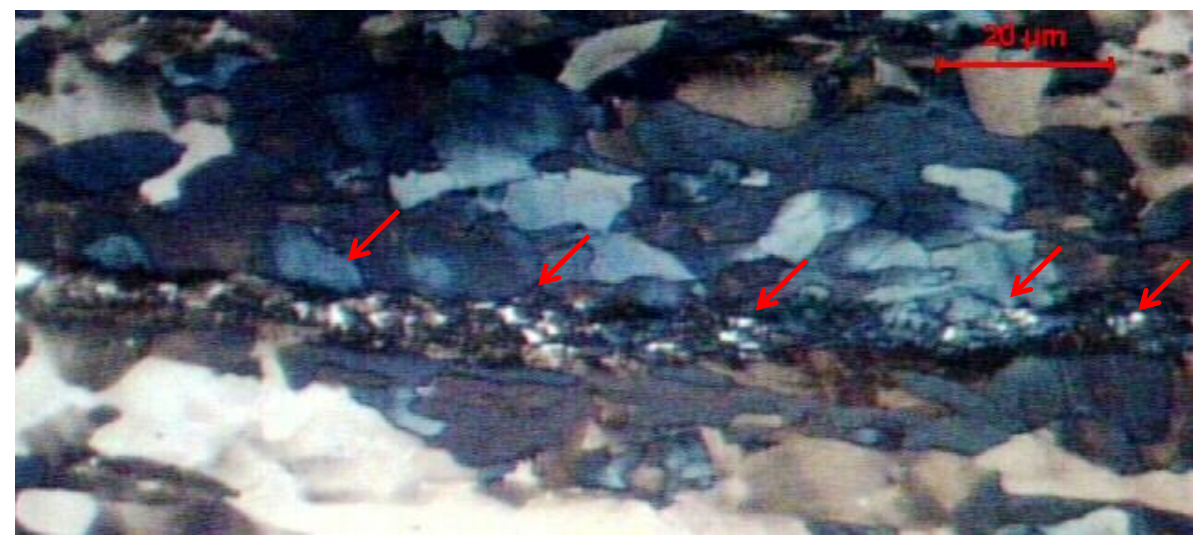

(a)

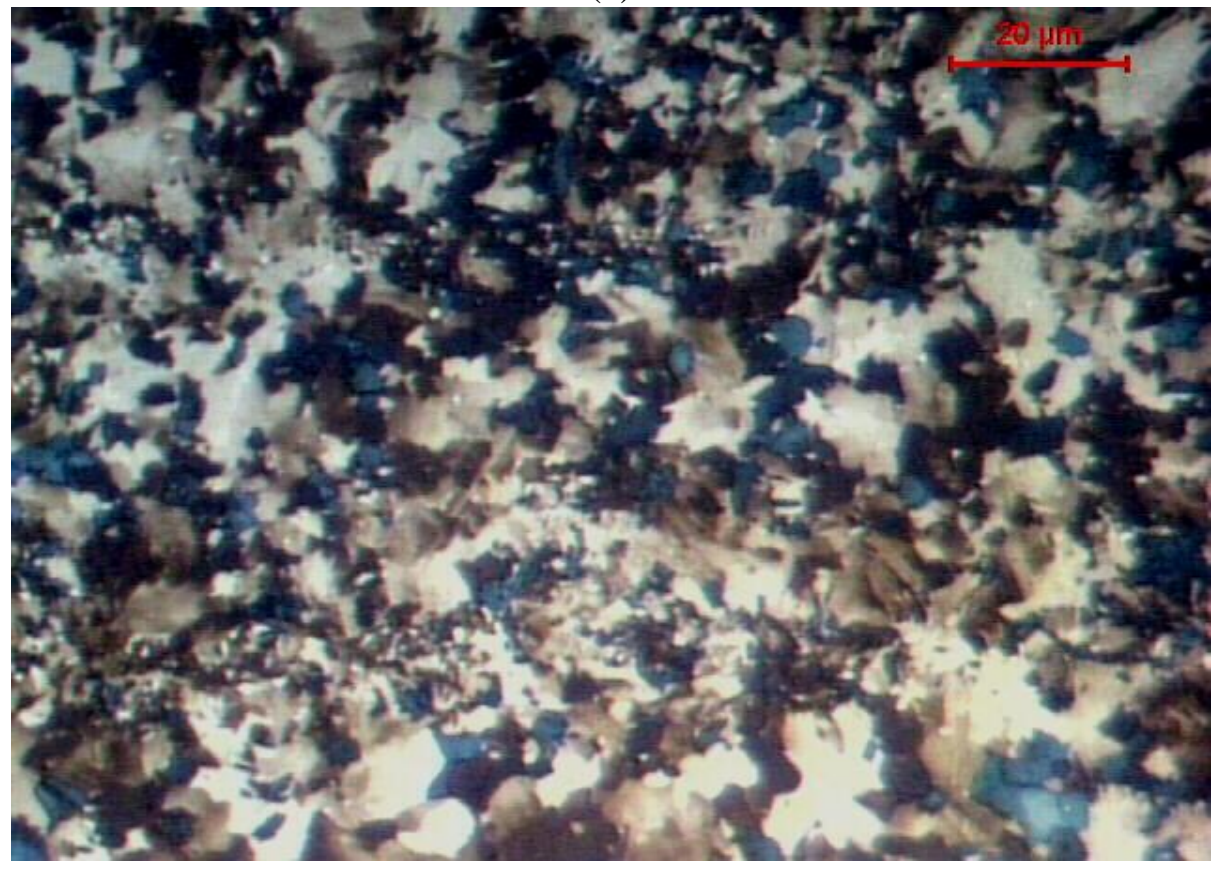

(b)

Figura 24. (a) Presença dos constituintes M-A na linha de segregação central do MB, indicadas pelas setas; (b) Presença dos constituintes M-A dispersos na ZTA. Aumento: 1000x. Coloração azulada e marrom: ferrita, branca: constituinte M-A.

A Figura 24 (a) apresenta os constituintes M-A ao longo da linha de segregação da chapa. Logo, dependendo da taxa de resfriamento aplicada ao material, haverá a presença de austenita retida em temperatura ambiente levando à formação destes constituintes M-A. Na Figura 24 (b), a presença dos constituintes M-A na ZTA apresenta-se mais distribuída e está relacionada com a maior taxa de resfriamento sofrida nesta região. Também foi encontrada a presença do microconstituinte M-A na linha de segregação central da chapa de um aço ARBL por Ogata (2009) como mostra a Figura 25. 


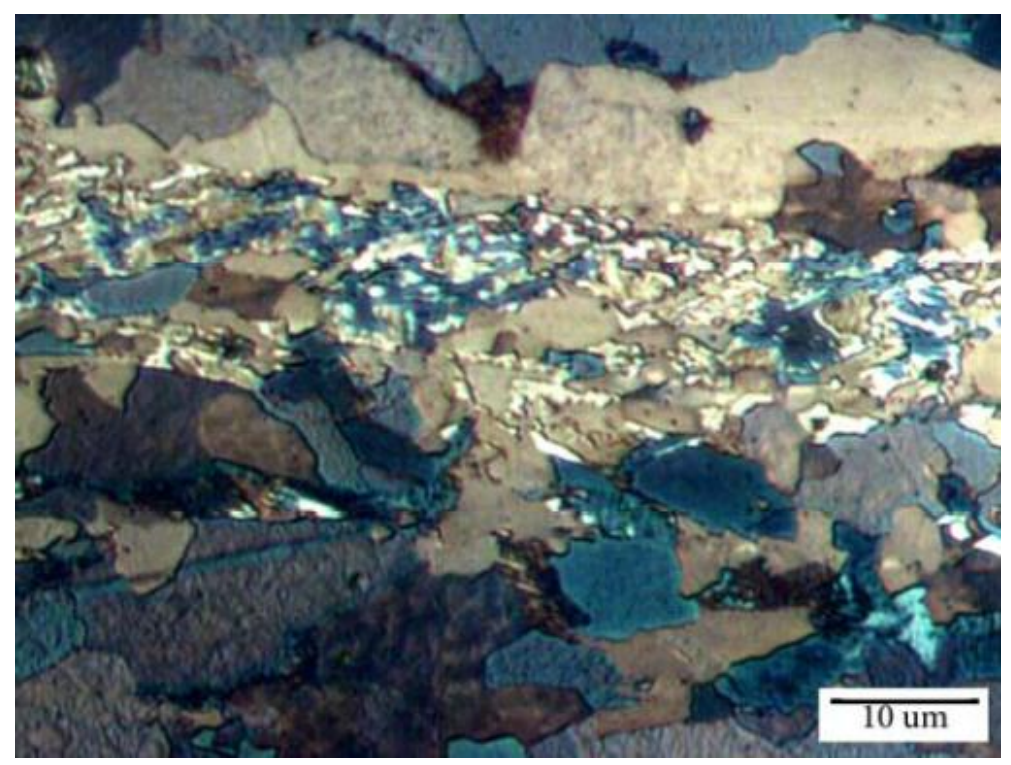

Figura 25. Detalhe da região central da chapa. MO com ampliação de 1000x. (OGATA, 2009)

A utilização do ataque químico LePera possibilitou caracterizar nas amostras soldadas a presença de bainita, através da coloração preta. A Figura 26 apresenta a amostra de $18 \mathrm{~mm} / \mathrm{s}$, na qual foi possível observar com maiores detalhes a presença de bainita. A presença de bainita para o mesmo aço em estudo também foi evidenciada por Pinto (2011).

\subsubsection{Medida da largura da ZTA}

A Figura 27 apresenta os resultados obtidos para a variação da largura da ZTA de acordo com a velocidade de soldagem utilizada. As medidas da largura da ZTA foram obtidas com o auxílio de microscopia óptica. Pode-se verificar que quanto maior a velocidade de soldagem utilizada, menor o aporte térmico, logo menor será a zona afetada pelo calor.

Pelo fato de a ZTA apresentar uma microestrutura bastante difusa ao longo de sua extensão, torna-se uma região mais propensa à propagação de trincas. Logo, se existir possibilidade de redução de sua extensão, menor será a probabilidade destes defeitos ocorrerem nesta região. 


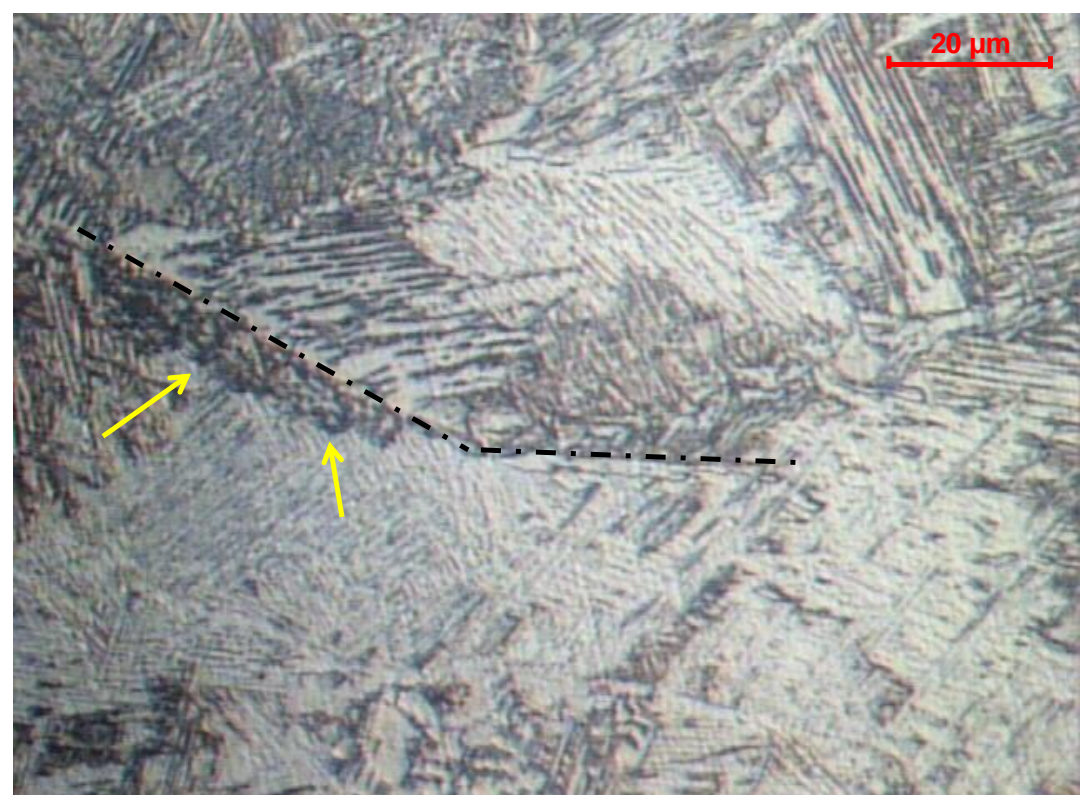

(a)

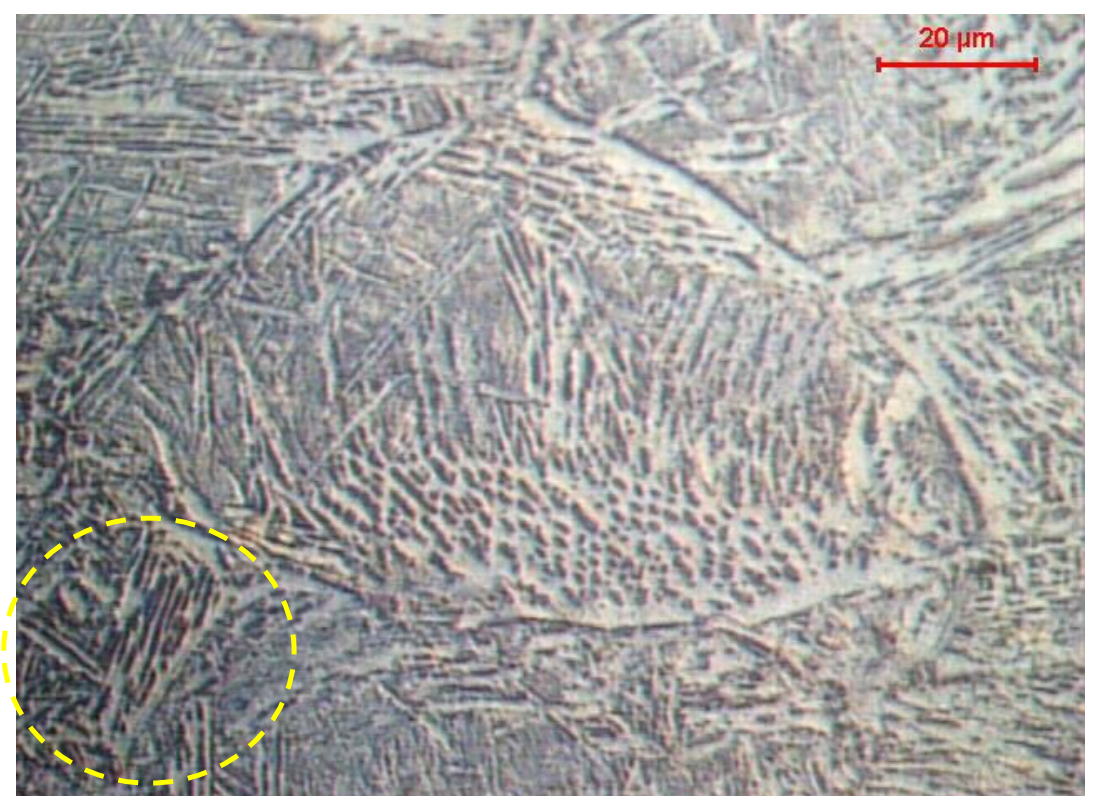

(b)

Figura 26. Presença de bainita na amostra de $18 \mathrm{~mm} / \mathrm{s}$. (a) Destaque para o início formação da bainita; (b) Destaque para a bainita formada próxima ao contorno de grão austenítico. 


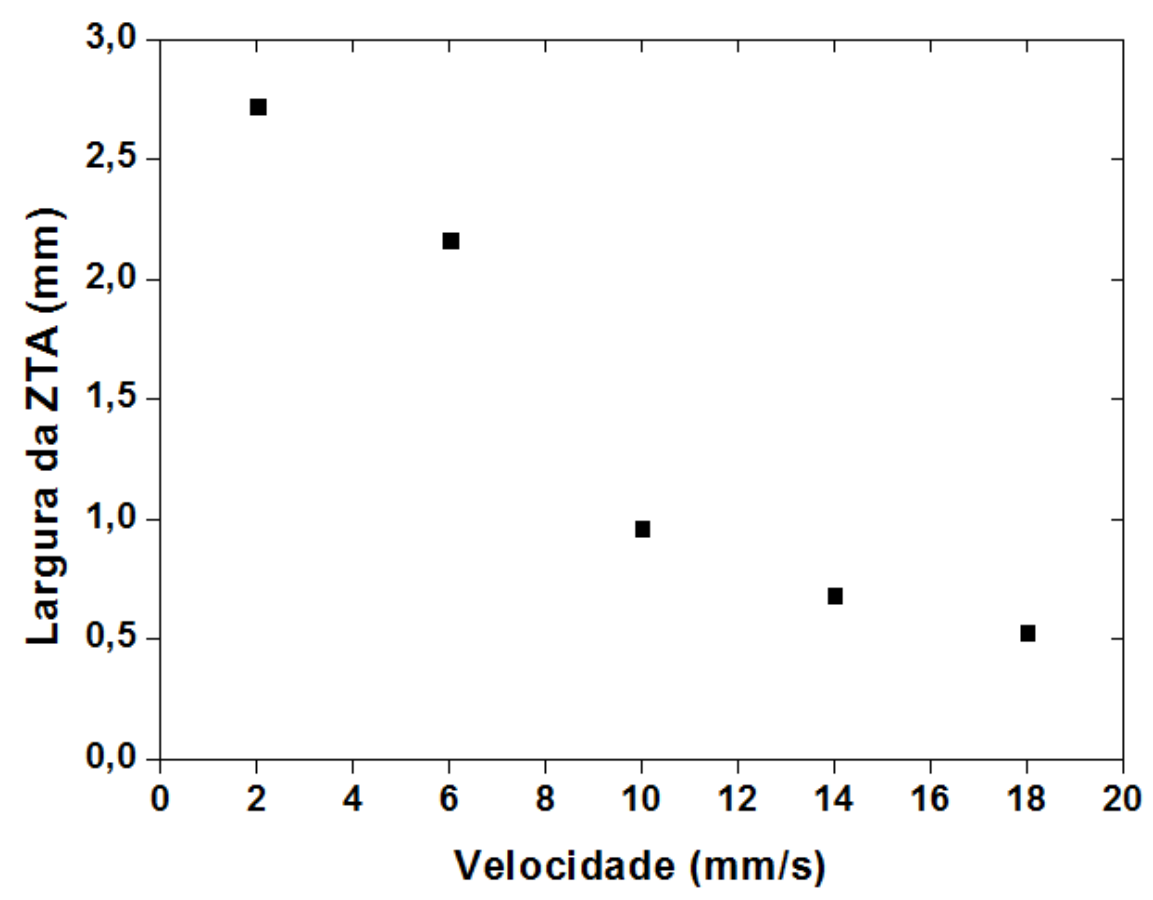

Figura 27. Largura da ZTA para as cinco condições de aporte térmico.

\subsubsection{Microscopia eletrônica de varredura}

A observação das microestruturas da ZF e da ZTA com o auxílio de microscopia eletrônica de varredura de alta resolução revela detalhes importantes. O primeiro deles é a morfologia da cementita na perlita degenerada na ZTA. A Figura 28 (a) mostra a morfologia da perlita lamelar encontrada no MB. Na Figura 28 (b) é possível visualizar a microestrutura da perlita degenerada presente na ZTA de uma amostra do aço API 5L X65 soldado por feixe de elétrons com velocidade de $14 \mathrm{~mm} / \mathrm{s}$. A mesma ampliação se aplica às duas micrografias. Nota-se uma mudança significativa na morfologia da cementita, que passa de lamelar à forma de blocos. Essa transição é gradual. Partículas grosseiras de cementita coexistem com partículas muito mais finas na perlita degenerada.

Numa outra seqüência de micrografias mostrada na Figura 29, foi possível evidenciar a presença tanto da bainita superior com blocos e carbonetos contínuos [Figura 29(a)] como da bainita inferior com carbonetos finos e segmentados [Figura 29 (b)] na ZF da mesma amostra. 


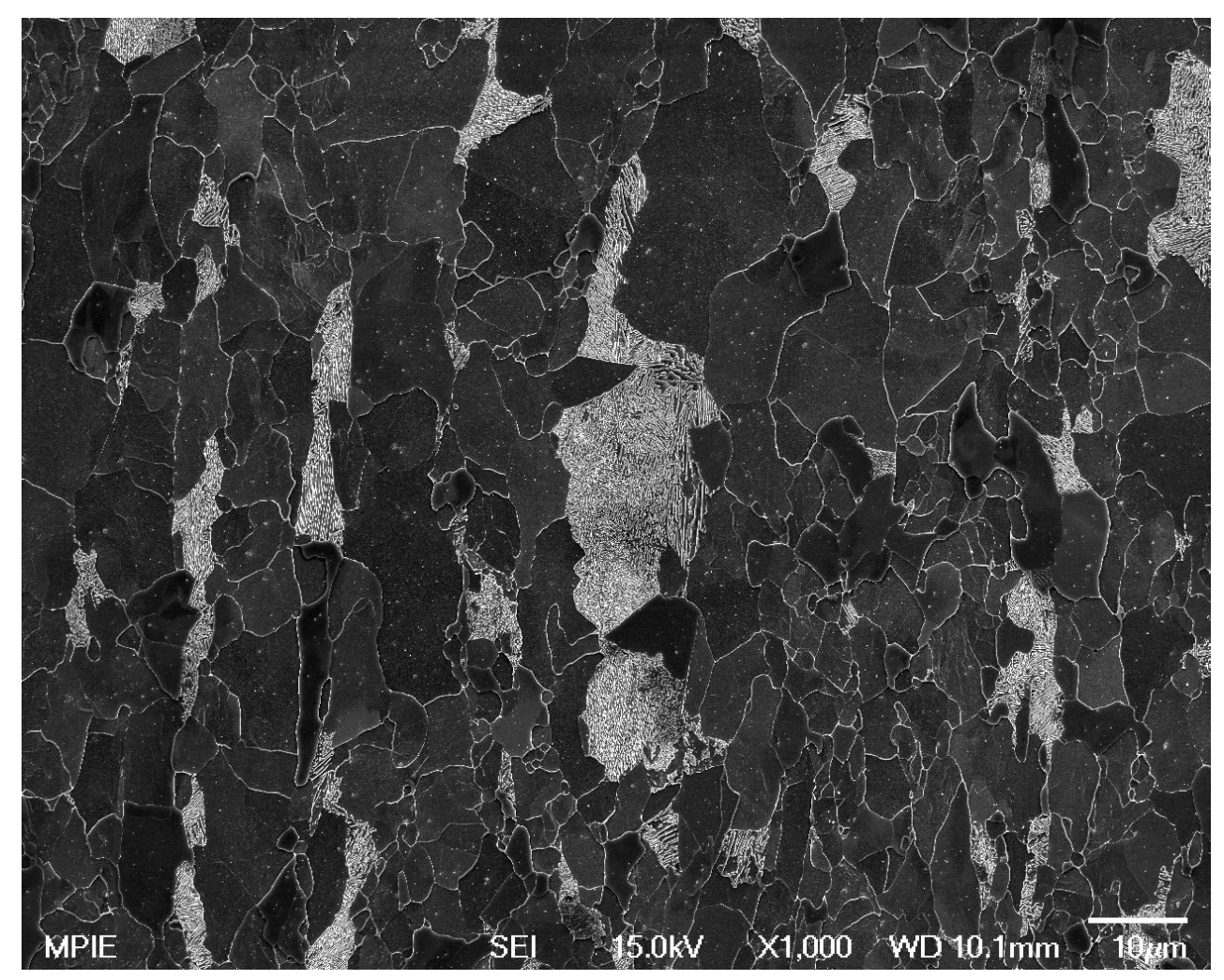

(a)

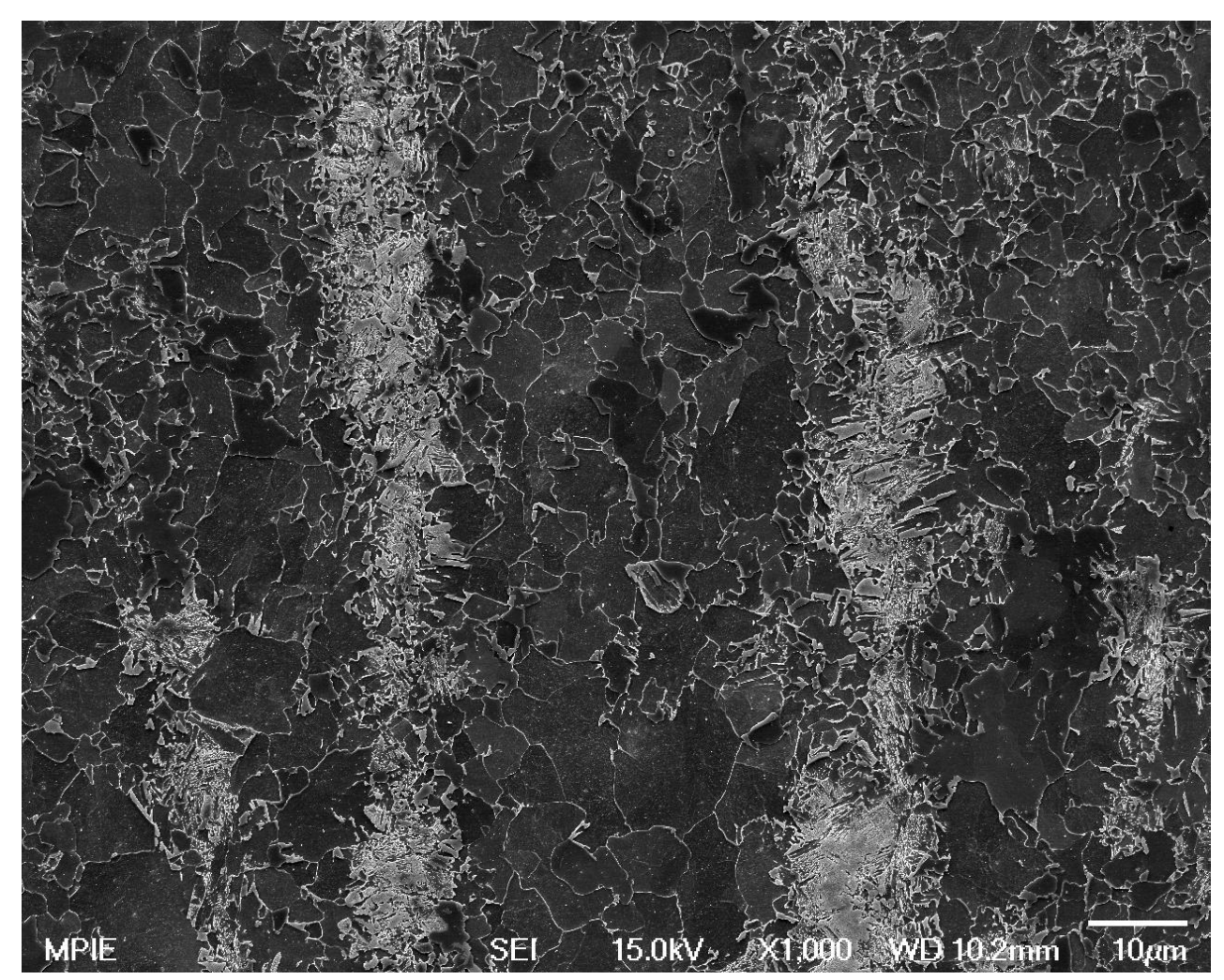

(b)

Figura 28. Microestrutura do aço API-5L X65 evidenciando aspectos morfológicos da: (a) perlita lamelar no MB; (b) perlita degenerada na ZTA (elétrons secundários). 


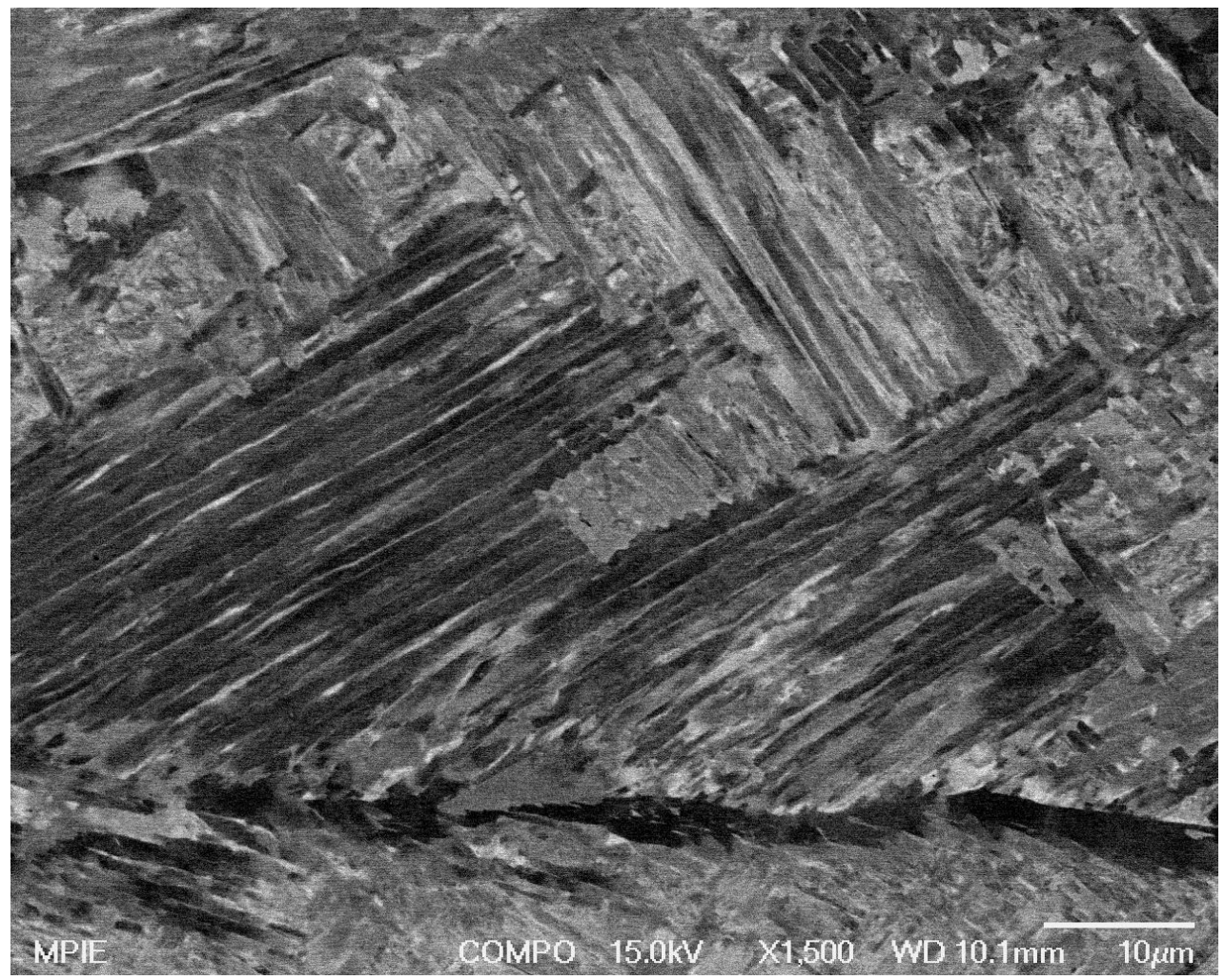

(a)

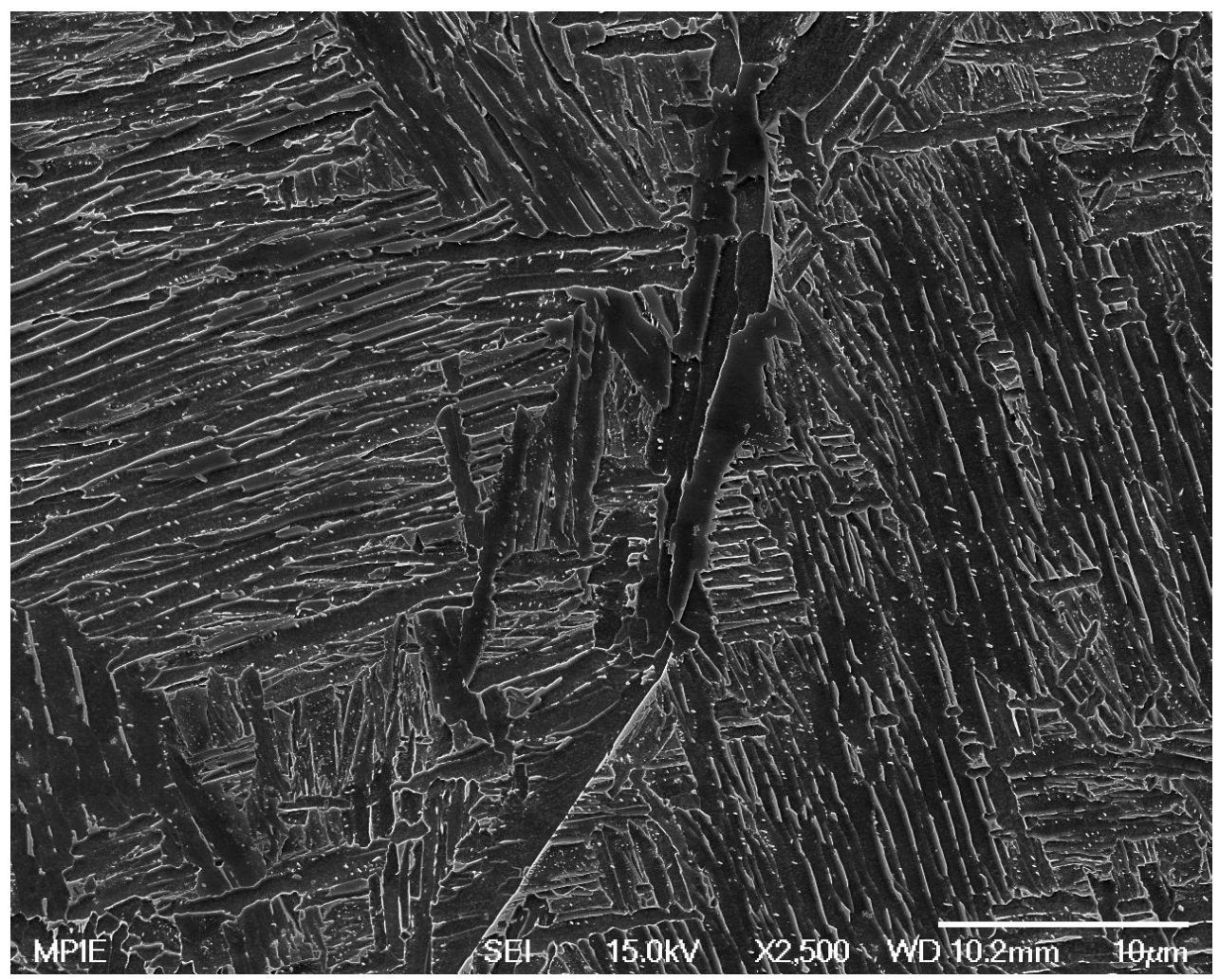

(b)

Figura 29. Microestrutura do aço API-5L X65 na ZF evidenciando a presença dos constituintes: (a) bainita superior (elétrons retroespalhados); (b) bainita inferior (elétrons secundários). 


\subsubsection{Microdureza Vickers}

Os resultados dos ensaios de microdureza Vickers foram obtidos a partir de medições realizadas na seção transversal da região soldada. As Figuras 30, 31,32, 33 e 34 apresentam os perfis de microdureza Vickers para as cinco velocidades de soldagem avaliadas neste estudo ao longo do topo, centro e raiz do cordão de solda. $X_{\mathrm{r}}$ representa a distância ao longo do centro do cordão de solda. De acordo com a Figura 30, os valores médios de dureza no MB, ZTA e ZF, comparadas no topo e no centro apresentam valores muito próximos. Isso fornece informações quanto à similaridade ao longo do cordão de solda em termos de dureza. Esses resultados também permitem concluir que o perfil de dureza segue como o esperado, valores mais elevados na interface ZTA-ZF e na ZF, comparados com o MB. Pelo fato de a velocidade de $2 \mathrm{~mm} / \mathrm{s}$ ter gerado um elevado aporte térmico, a chapa vazou durante a fusão. Não se mediu o perfil de dureza ao longo da raiz nessa amostra.

A Figura 31 exibe os valores médios de dureza no MB, ZTA e ZF, comparadas no topo, no centro e na raiz apresentam valores muito próximos. Esses valores garantem que mesmo com a transformação sofrida pelo material quando soldado, as propriedades de dureza continuam similares ao MB. Quando comparada com a amostra de $2 \mathrm{~mm} / \mathrm{s}$, a de 6 $\mathrm{mm} / \mathrm{s}$ apresenta uma taxa de resfriamento um pouco mais acentuada, refletindo nos valores mais elevados de dureza. A seta vermelha ao longo da raiz da amostra de $6 \mathrm{~mm} / \mathrm{s}$ indica o alto valor de dureza devido os pontos medidos ao longo da linha de segregação.

A Figura 32 apresenta os valores médios de dureza no MB, ZTA e ZF, comparadas no topo, no centro e na raiz apresentam valores muito próximos, para a amostra de 10 $\mathrm{mm} / \mathrm{s}$. Valores de dureza aproximados indicam similaridade ao longo de toda a seção medida. Isso garante que mesmo o material sendo soldado, as condições estabelecidas quanto aos parâmetros e condições de resfriamento foram escolhidas de maneira adequada, gerando valores de microdureza similares ao longo da região soldada com o MB. 

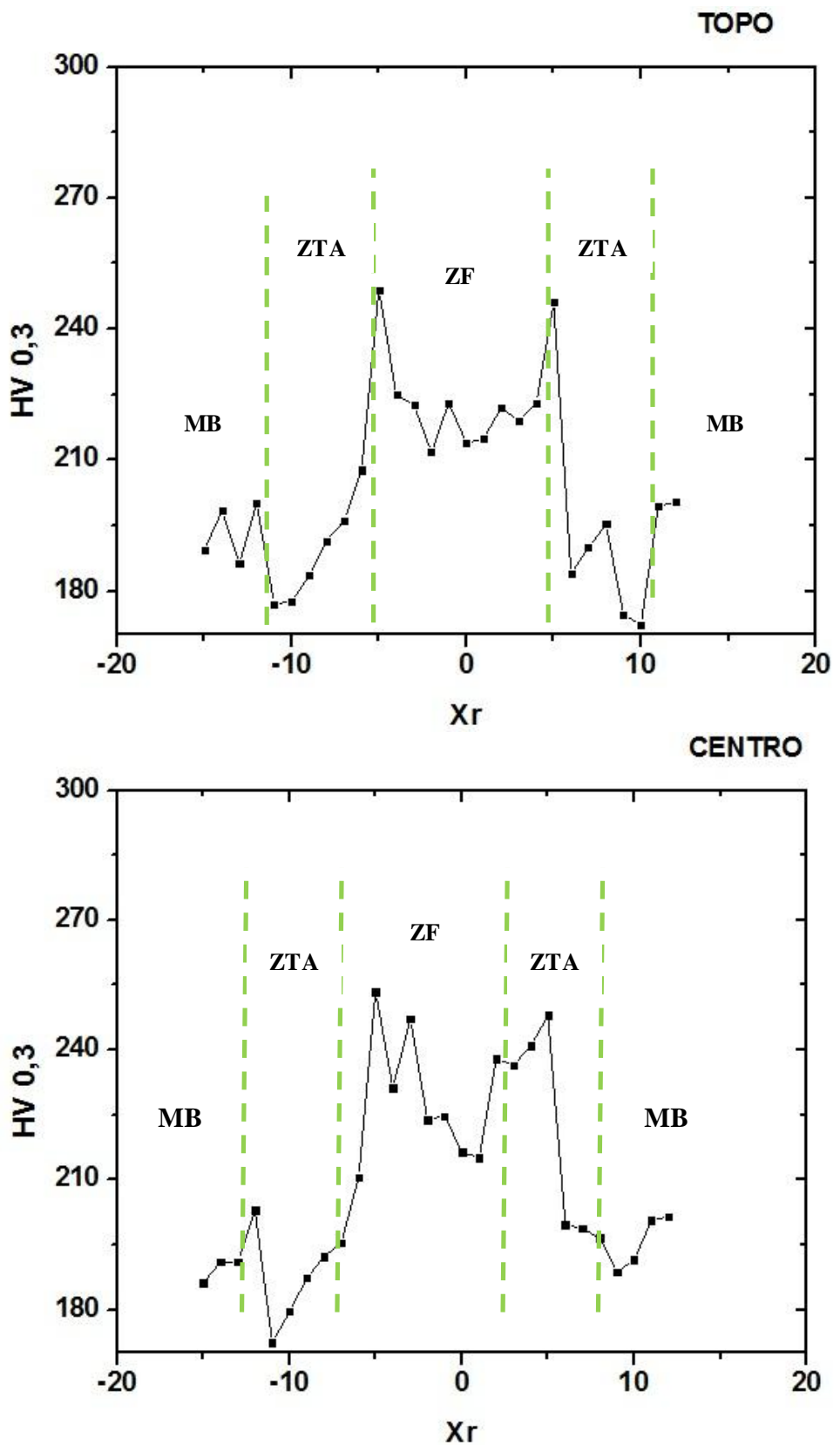

Figura 30. Perfil de microdureza Vickers da junta soldada com velocidade de $2 \mathrm{~mm} / \mathrm{s}$. 
Conforme a velocidade de soldagem aumenta, a taxa de resfriamento também aumenta, refletindo nos valores mais elevados de dureza. A seta em vermelho indicada no perfil de dureza da ZF da região do topo da amostra de $10 \mathrm{~mm} / \mathrm{s}$ representa a queda de dureza devido a medição de um ponto localizado na fase ferrita alotriomórfica.

Na Figura 33, os valores médios de dureza no MB, ZTA e ZF, comparadas no topo, no centro e na raiz apresentam valores muito próximos na amostra soldada com velocidade de $14 \mathrm{~mm} / \mathrm{s}$. O aumento na velocidade de soldagem eleva a taxa de resfriamento sofrida pela região soldada. Sendo assim, fases mais duras tendem e a morfologia da microestrutura se torna mais acicular. Os valores elevados de dureza na ZF refletem a maior quantidade de ferrita de Widmanstätten, as quais foram observadas via MO atacadas com Nital $2 \%$.

A Figura 34 mostra os valores médios de dureza no MB, ZTA e ZF. Os valores no topo, no centro e na raiz são muito próximos. A amostra soldada com velocidade de 18 $\mathrm{mm} / \mathrm{s}$ é a que apresenta a maior taxa de resfriamento. Nesta amostra foi possível verificar as elevadas durezas na ZF. De acordo com ASM (1983) os valores observados na ZF da amostra de $18 \mathrm{~mm} / \mathrm{s}$ indicam valores de dureza encontrados em estruturas bainíticas. 

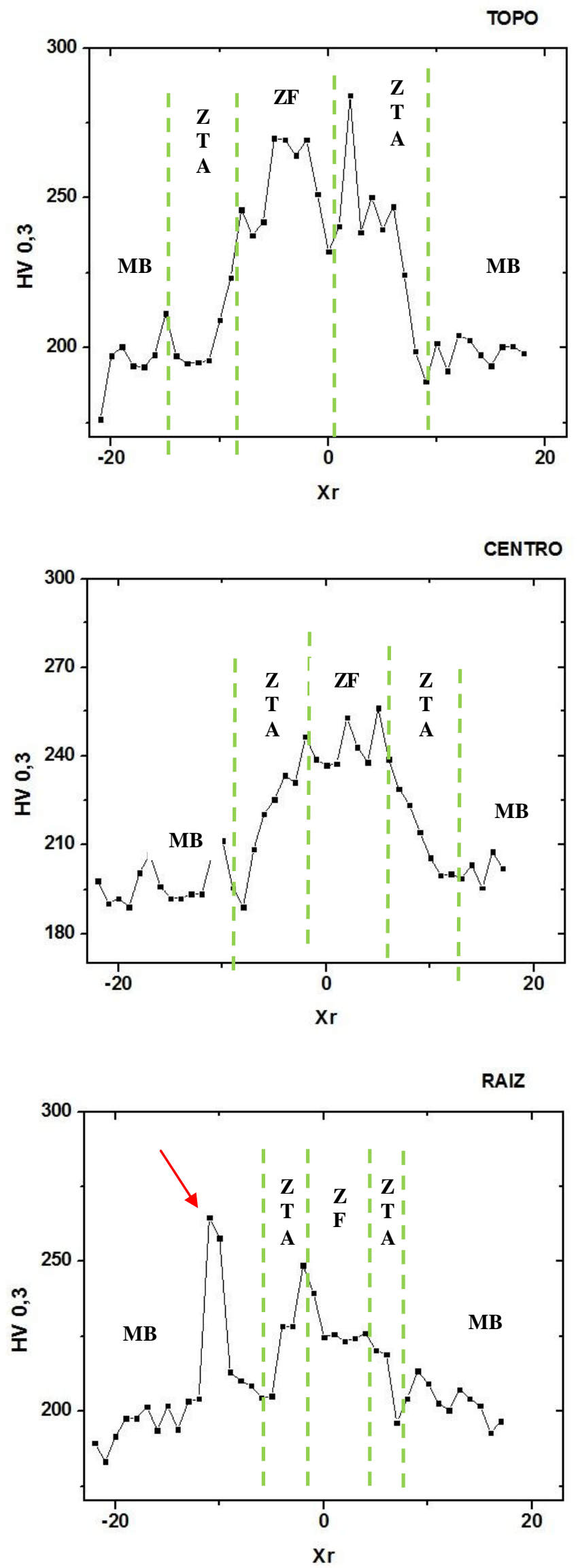

Figura 31. Perfil de microdureza Vickers da junta soldada com velocidade de $6 \mathrm{~mm} / \mathrm{s}$. 

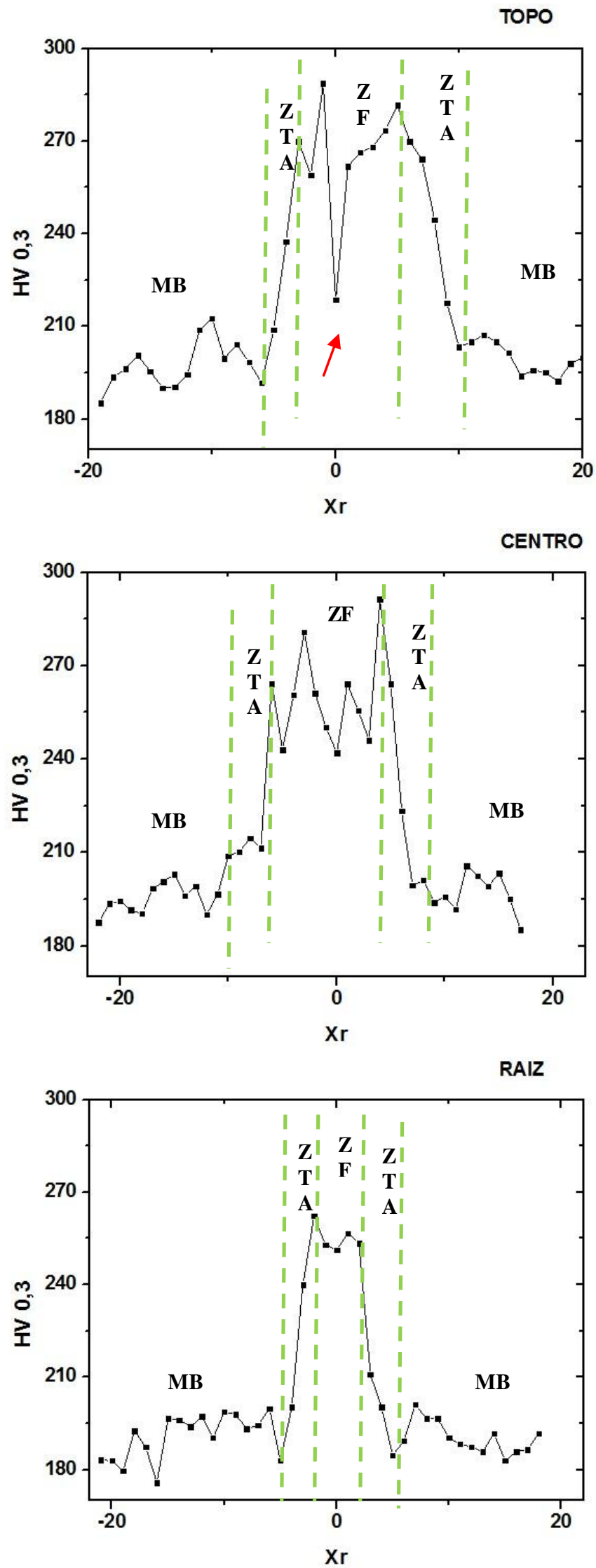

Figura 32. Perfil de microdureza Vickers da junta soldada com velocidade de $10 \mathrm{~mm} / \mathrm{s}$. 

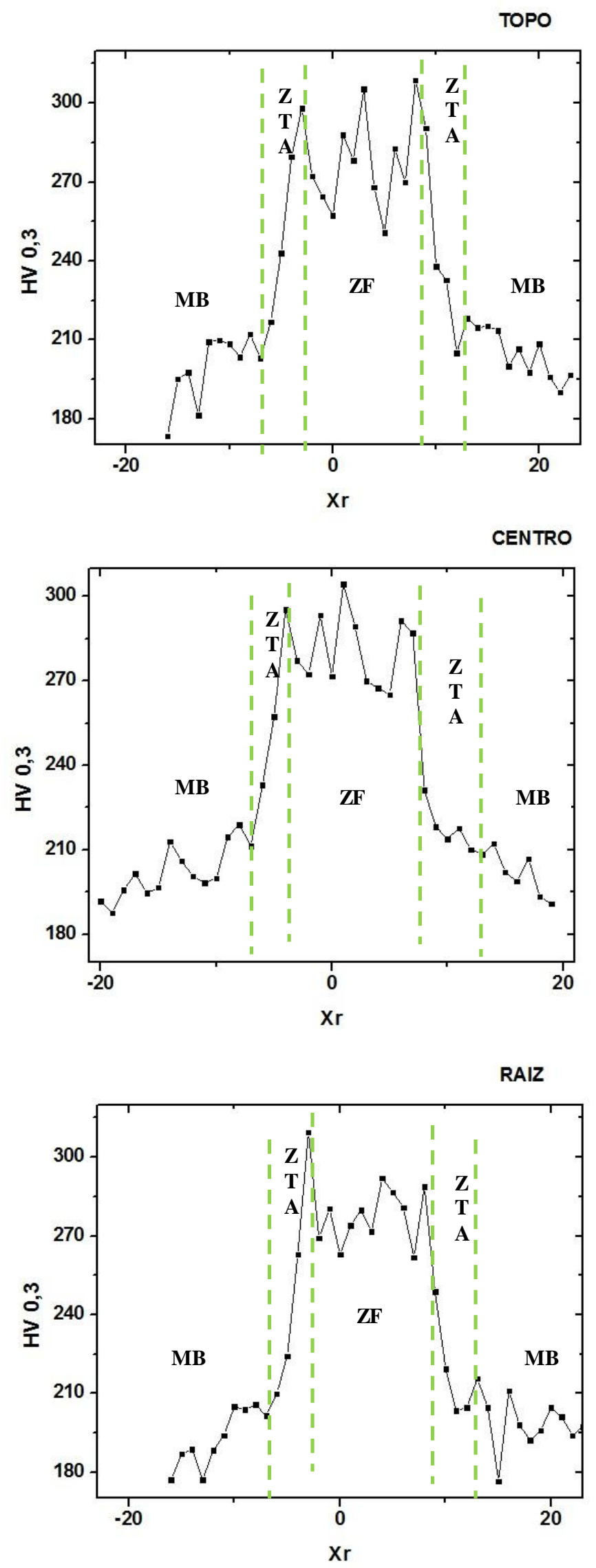

Figura 33. Perfil de microdureza Vickers da junta soldada com velocidade de $14 \mathrm{~mm} / \mathrm{s}$. 

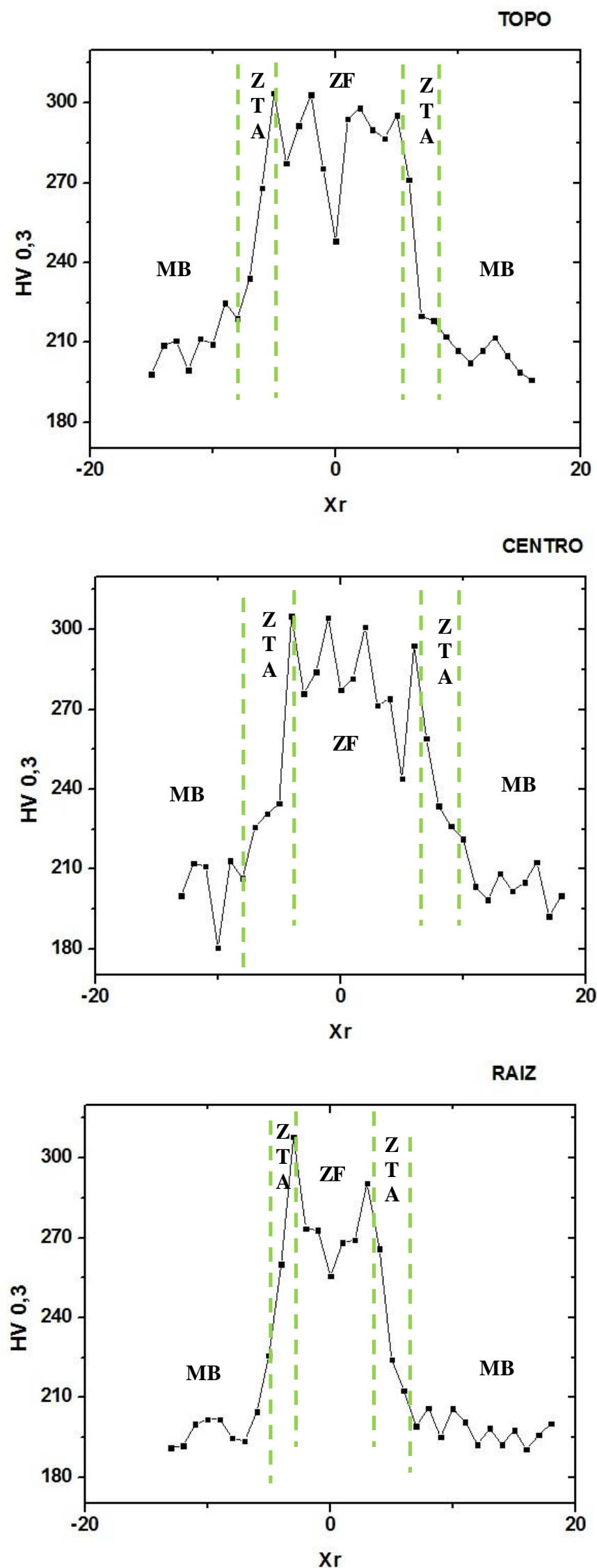

Figura 34. Perfil de microdureza Vickers da junta soldada com velocidade de $18 \mathrm{~mm} / \mathrm{s}$. 
A Tabela 7 apresenta os resultados de microdureza Vickers para cada velocidade de soldagem nas regiões de interesse na solda, permitindo uma visão global dos resultados encontrados neste estudo. Nela é possível observar que as regiões mais duras se encontram na amostra de $18 \mathrm{~mm} / \mathrm{s}$.

Dentre as regiões medidas para cada amostra (topo, centro, raiz) não houve uma variação expressiva entre os valores de microdureza obtidos. Dessa forma, foi possível observar que a região soldada apresenta uma distribuição mais homogênea de microestruturas, as quais são responsáveis pelos valores de dureza encontrados. Logo, as propriedades ao longo do cordão tendem a apresentar valores próximos, mantendo a integridade estrutural do material soldado. Outra comparação foi realizada para o perfil de dureza das cinco juntas em estudo, nas três regiões onde foram medidas (topo, centro e raiz), conforme apresentado na Figura 35.

Tabela 7. Comparação da microdureza Vickers das cinco amostras em estudo

\begin{tabular}{|c|c|c|c|c|}
\hline \multirow{2}{*}{\multicolumn{2}{|c|}{ Amostras }} & \multicolumn{3}{|c|}{ Microdureza Vickers } \\
\hline & & \multirow{3}{*}{$\begin{array}{c}\text { MB } \\
196 \pm 6 \\
195 \pm 7\end{array}$} & \multirow{3}{*}{$\begin{array}{c}\text { ZTA } \\
186 \pm 11 \\
192 \pm 10 \\
\end{array}$} & \multirow{3}{*}{$\begin{array}{c}\mathbf{Z F} \\
225 \pm 12 \\
234 \pm 13\end{array}$} \\
\hline & Topo & & & \\
\hline $2 \mathrm{~mm} / \mathrm{s}$ & Centro & & & \\
\hline \multirow{3}{*}{$6 \mathrm{~mm} / \mathrm{s}$} & Topo & $197 \pm 7$ & $224 \pm 13$ & $260 \pm 17$ \\
\hline & Centro & $198 \pm 7$ & $218 \pm 15$ & $243 \pm 8$ \\
\hline & Raiz & $201 \pm 6$ & $216 \pm 13$ & $230 \pm 10$ \\
\hline \multirow{3}{*}{$10 \mathrm{~mm} / \mathrm{s}$} & Topo & $198 \pm 7$ & $226 \pm 21$ & $266 \pm 20$ \\
\hline & Centro & $196 \pm 6$ & $214 \pm 21$ & $260 \pm 15$ \\
\hline & Raiz & $191 \pm 7$ & $203 \pm 21$ & $255 \pm 4$ \\
\hline \multirow{3}{*}{$14 \mathrm{~mm} / \mathrm{s}$} & Topo & $202 \pm 12$ & $238 \pm 22$ & $279 \pm 19$ \\
\hline & Centro & $201 \pm 8$ & $232 \pm 25$ & $282 \pm 14$ \\
\hline & Raiz & $195 \pm 10$ & $221 \pm 21$ & $280 \pm 13$ \\
\hline \multirow{3}{*}{$18 \mathrm{~mm} / \mathrm{s}$} & Topo & $202 \pm 7$ & $238 \pm 25$ & $288 \pm 16$ \\
\hline & Centro & $204 \pm 10$ & $235 \pm 13$ & $283 \pm 18$ \\
\hline & Raiz & $198 \pm 5$ & $238 \pm 24$ & $277 \pm 18$ \\
\hline
\end{tabular}



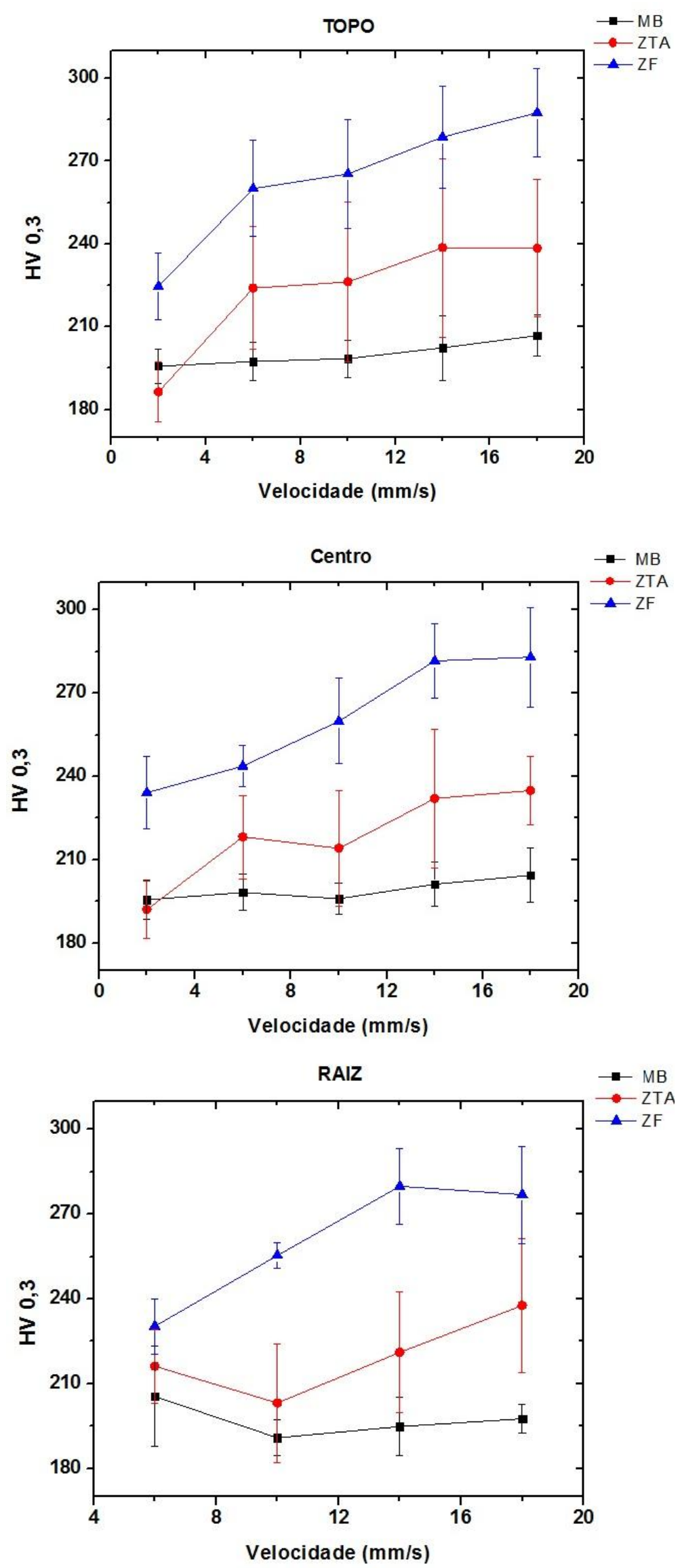

Figura 35. Comparação das diferentes regiões de medição de microdureza Vickers (topo, centro e raiz) das cinco amostras em estudo. 
A partir da Figura 35 é possível verificar como a velocidade de soldagem afeta o perfil de dureza. Para maiores velocidades, a taxa de resfriamento também aumenta, aproximando-se das taxas encontradas na têmpera dos aços. As três regiões medidas apresentam valores de dureza do MB, ZTA e ZF bastante próximos. Para a localização da raiz apenas 4 pontos foram apresentados, pois na amostra soldada com $2 \mathrm{~mm} / \mathrm{s}$ não se mediu a dureza na raiz. A dureza aumenta com a taxa de resfriamento, pois a morfologia torna-se mais acicular e a fração de agregados eutetóides também é maior.

\subsubsection{Difração de raios $X$}

Com a análise via difração de raios $\mathrm{X}$ foi possível verificar a presença de austenita retida nas amostras em estudo. A Figura 36 apresenta os difratogramas das amostras soldadas com velocidades de $6 \mathrm{~mm} / \mathrm{s}$ e de $14 \mathrm{~mm} / \mathrm{s}$. Bowker (1993), Batista (2002) e Terada (2004) relataram o efeito negativo na tenacidade à fratura de aços ARBL, devido à presença do constituinte M-A que elevam a temperatura de transição dúctil-frágil ou diminuem a energia absorvida nos testes de impacto.

O efeito fragilizador dos constituintes M-A diminui quando eles se apresentam em pequenas frações e com morfologia mais acicular e dispersa (BATISTA, 2003; ZHONG, 2006; MARTIN, 2007). No presente estudo, foi observada a presença do constituinte M-A em regiões da ZTA e ZF. Devido à incompleta transformação, há alguma austenita retida em temperatura ambiente. É importante ressaltar que esta fase é indesejável por ser metaestável e poder vir a se transformar em serviço. 

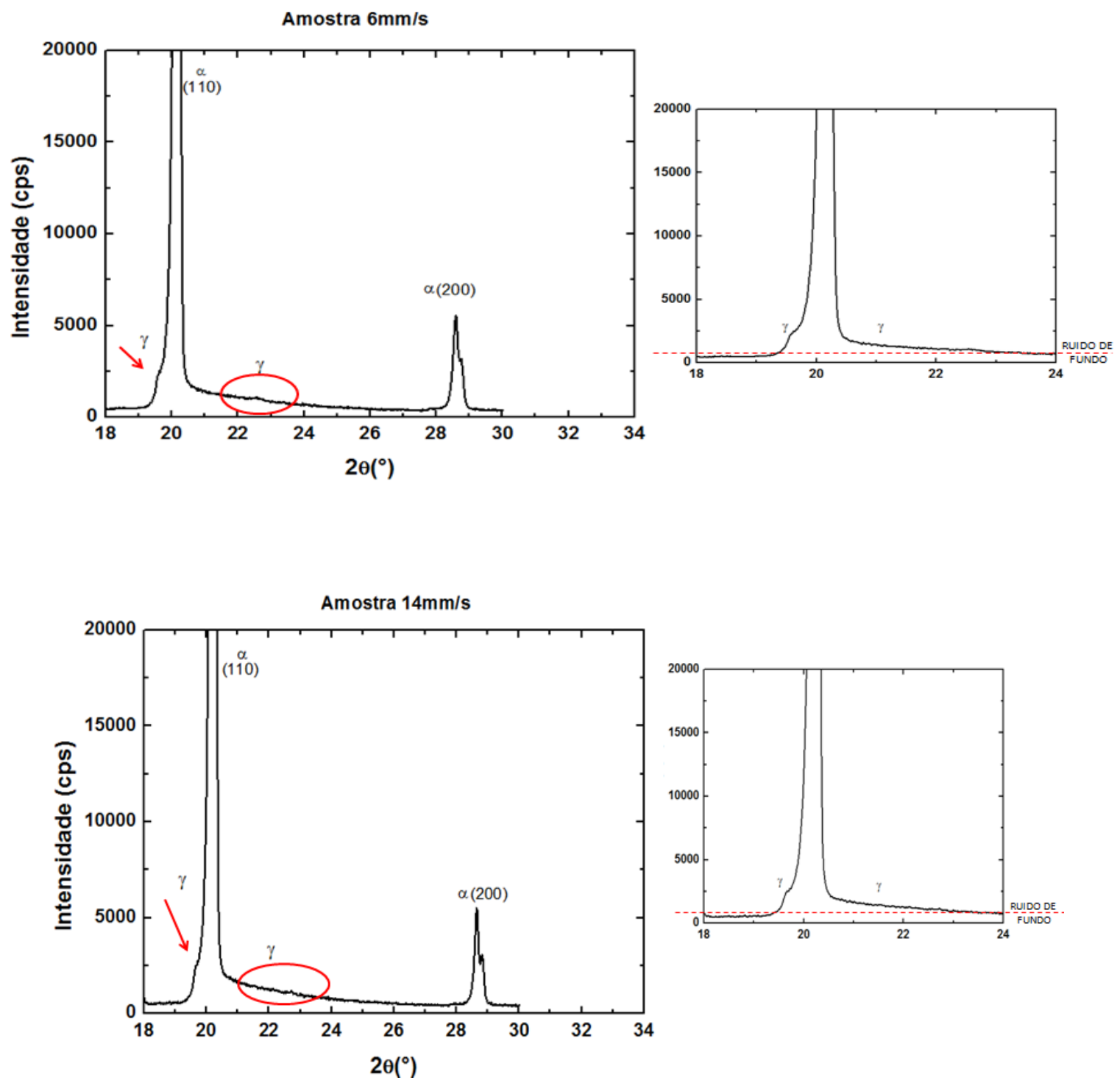

Figura 36. Difratogramas de raios X na ZF das amostras soldadas com velocidades de $6 \mathrm{~mm} / \mathrm{s}$ e 14 $\mathrm{mm} / \mathrm{s}$.

\subsection{TAXA DE RESFRIAMENTO}

Seguindo o modelo matemático proposto por Schiller (1982) foi possível estimar a taxa de resfriamento. As Equações 1-3 foram utilizadas para estimar a taxa de resfriamento em cada condição de soldagem. A Tabela 8 apresenta os valores calculados de taxa de resfriamento para cada amostra em relação à espessura da chapa soldada. 
Tabela 8. Taxa de resfriamento calculada para as cinco velocidades de soldagem.

\begin{tabular}{cc}
\hline Amostra & Taxa de resfriamento $\left({ }^{\circ} \mathbf{C} / \mathbf{s}\right)$ \\
\hline $\mathbf{2 ~} \mathbf{~ m} / \mathbf{s}$ & 21,5 \\
\hline $\mathbf{6 ~ m m} / \mathbf{s}$ & 46,9 \\
\hline $\mathbf{1 0 ~ \mathbf { m }} / \mathbf{s}$ & 60,6 \\
\hline $\mathbf{1 4} \mathbf{~ m m} / \mathbf{s}$ & 71,7 \\
\hline $\mathbf{1 8 ~ \mathbf { m m } / \mathbf { s }}$ & 81,3 \\
\hline
\end{tabular}

Com os resultados apresentados na Tabela 8, é possível verificar que no processo de soldagem por feixe de elétrons se obtém elevados valores de taxa de resfriamento, dependendo da escolha dos parâmetros de soldagem. As taxas de resfriamento típicas numa barra de aço com diâmetro de 1" são mostradas na Tabela 9 (ASKELAND, 2006).

Tabela 9. Taxas de resfriamento típicas para uma barra de aço em diferentes meios

\begin{tabular}{cc}
\hline Meio & Taxa de resfriamento $\left({ }^{\circ} \mathbf{C} / \mathbf{s}\right)$ \\
\hline Óleo (sem agitação) & 18 \\
\hline Óleo (com agitação) & 45 \\
\hline $\mathbf{H}_{\mathbf{2} 0}$ (sem agitação) & 45 \\
\hline $\mathbf{H}_{\mathbf{2} 0}$ (com agitação) & 190 \\
\hline Salmoura (sem agitação) & 90 \\
\hline Salmoura (com agitação) & 230 \\
\hline
\end{tabular}

Comparando-se os valores das taxas de resfriamento calculadas com os valores das taxas de resfriamento típicas para uma barra de aço de 1" de diâmetro reportadas na literatura (ASKELAND, 2006), pode-se dizer que as amostras soldadas com velocidades de $6 \mathrm{~mm} / \mathrm{s}$ a $18 \mathrm{~mm} / \mathrm{s}$ apresentam taxas de resfriamento similares às encontradas nos meios típicos utilizados para a têmpera de aços, como é o caso da água e do óleo sem agitação.

Conforme indicado na CCT do aço API 5L X65 (Figura 6), pode-se observar que para uma taxa de $39^{\circ} \mathrm{C} / \mathrm{s}$ temos a formação de bainita e pequenas frações de martensita. O constituinte bainita foi encontrado na ZF nas amostras soldadas entre 6 e $18 \mathrm{~mm} / \mathrm{s}$ por meio de metalografia colorida via $\mathrm{MO}, \mathrm{MEV}$ de alta resolução e medidas de microdureza Vickers. Mesmo com a pequena quantidade de martensita esperada para as condições mais intensas de resfriamento, ainda assim foi possível evidenciar a presença de austenita retida 
em pequenas quantidades via DRX, sugerindo a presença de martensita, uma vez que essa fase metaestável geralmente é associada ao constituinte M-A. Vale a ressalva de que a curva CCT é construída em condições distintas daquelas observadas na ZF de uma solda.

Uma solução para diminuir as taxas de resfriamento e, consequentemente, diminuir a probabilidade de defeitos a ela associada seria a realização de pré-aquecimento na chapa e/ou pós-aquecimento. O tratamento de pós-aquecimento na junta soldada é fundamental para evitar a fragilização por hidrogênio no material soldado. O calor favorece a remoção do gás hidrogênio. Após o resfriamento de uma junta soldada, a ZTA fica submetida a um sistema de tensões residuais e estas tensões são tipicamente componentes de tração que podem nuclear trincas com razoável facilidade. Esse é um dos motivos pelos quais a ZTA é considerada como região crítica após a soldagem. De modo a compensar este efeito negativo é usual a realização de um tratamento térmico de alívio de tensões pós-soldagem.

Para garantir as propriedades mecânicas da região soldada é recomendada a realização de tratamento térmico após a soldagem no material. No caso do aço em estudo, o tratamento térmico seria ideal para a desestabilização dos constituintes M-A, os quais aumentam a dureza da solda e podem causar a mudança repentina de fase no material em serviço. 


\section{CONCLUSÕES}

Os resultados da caracterização microestrutural realizada no aço API-5L X65 soldado por feixe de elétrons permitiram as seguintes conclusões:

a) Quanto maior a velocidade de soldagem, menor a relação penetração versus largura do cordão. Logo, uma velocidade de soldagem entre 2 e $10 \mathrm{~mm} / \mathrm{s}$, seria ideal para soldar tubos com paredes espessas por feixe de elétrons garantindo penetração total.

b) A linha de segregação central rica em manganês observada no MB foi completamente removida na $Z T A$ e na $Z F$. Acredita-se que a elevada temperatura foi suficiente para solubilizar o Mn na microestrutura.

c) Com auxílio dos diferentes ataques metalográficos (Nital $2 \%$, Klemm 1 e LePera) foi possível caracterizar as três regiões de da chapa soldada e determinar as fases e os constituintes presentes em cada uma delas:

- O MB possui uma estrutura típica dos aços ARBL, com uma matriz de grãos ferríticos alternados com bandas perlíticas alinhadas paralelamente à direção de laminação da chapa. Com o ataque de Klemm observou-se a presença de constituintes M-A ao longo da linha de segregação central da chapa, mais rica em manganês.

- A ZTA é bastante estreita. Três regiões são observadas ao longo da ZTA. A primeira próxima ao MB apresenta uma estrutura de perlita degenerada. Mais para o centro da zona, a microestrutura se apresenta bastante refinada, pela transformação da $\gamma \rightarrow \alpha$. Próximo à linha de fusão, observa-se uma região mais grosseira e com uma dureza mais elevada quando comparada às outras regiões. Regiões com constituintes MA foram observadas na ZTA de forma distribuída ao longo de sua estrutura mais refinada. 
- A ZF possui uma microestrutura mais homogênea, típica dos aços ARBL soldados, com as fases ferrita alotriomórfica, ferrita acicular, ferrita de Widmänstatten e bainita (superior e inferior).

d) A largura da ZTA aumenta à medida que a velocidade de soldagem diminui em função do aumento do aporte térmico.

e) A microdureza Vickers das três regiões medidas (topo, centro e raiz), no MB, na ZTA e na ZF, para cada amostra, foram muito próximas. Para as amostras soldadas com maior velocidade, o perfil de dureza apresentou valores mais elevados. Velocidades de soldagem mais elevadas produzem taxas de resfriamento mais acentuadas, permitindo a formação de fases mais duras.

f) Os resultados de difração de raios $\mathrm{X}$ permitem concluir que existe austenita retida no material, corroborando os resultados obtidos via microscopia óptica com ataque Klemm 1. A intensidade do pico é devida a baixa fração volumétrica desta fase.

h) A soldagem por feixe de elétrons mostrou-se viável podendo ser aplicada na soldagem de tubos com paredes espessas, principalmente pela sensível redução da extensão da ZTA. O desenvolvimento tecnológico para a substituição das câmaras de vácuo, que limitaria o tamanho de peça a ser soldada, não inviabiliza o uso desta tecnologia de soldagem na eventual fabricação de tubos para o transporte de óleo e gás. Essa vantagem seria ainda maior na soldagem de tubos com estrutura bainítica (graus X100 e X120, por exemplo), uma vez que o engrossamento microestrutural seria muito menos pronunciado do que o observado na soldagem por arco submerso. 


\section{REFERÊNCIAS}

API - AMERICAN PETROLEUM INSTITUTE. Specification for Line Pipe - API

Specification 5L. 42 ${ }^{\text {nd }}$ Edition. Washington, July, 2000.

ANP - Agência Nacional de Petróleo. Anuário Estatístico de 2008. Rio de Janeiro, 2008.

ASTM E 384-99 Standard Test Method for Knoop and Vickers Hardness of Materials. p.1-25, 2010.

ASTM E 562-08 Standard Test Method for Determining Volume Fraction by Systematic Manual Point Count. p.1-6, 2008.

ASTM E 975-03 Standard Practice for X - Ray Determination of Retained Austenite in Steel with Near Random Crystallographic Orientation, 2008.

ASKELAND, D. R. The Science and Engineering of Materials. $3^{\text {rd }}$ ed. Boston: PWS Publishing Company. 2006. Cap. 12, p. 348.

AKSELSEN, O. M., GRONG, O., RORVIK, G. Embrittlement phenomena in the grain coarsened heat affected zone of low carbon microalloyed steels. Scandinavian Journal Materials Science and Technology of Metallurgy, v.19, p. 258-264, 1990.

AKSELSEN, O. M.; RORVIK, G.; KLUKEN, A. O. Prediction of tensile properties of intercritical heat affected zone., Materials Science and Technology, v.10, n.1, p.75-80, 1994.

AKSELSEN, O. M.; SOLBERG, J. K. ; GRONG, O. Effects of martensite-austenite (M-A) islands on intercritical heat-affected zone toughness of low carbon microalloyed. ISIJ International steels. Scandinavian Journal of Metallurgy, v. 17, p.194-200, 1988. 
AKSELSEN, O. M., GRONG, O., SOLBERG, J. K. Structure-property relationships in intercritical heat affected zone of low-carbon microalloyed steels. Materials Science and Technology, v.3, n 8, p.649-655, 1987.

API (AMERICAN PETROLEUM INSTITUTE). Specification for Pipe Line API Specification 5L. $42^{\text {nd }}$ Ed. 2000.

ASM Metals Handbook; Welding and Brazing, $9^{\text {th }}$ ed. Ohio, 1983. v. 6, p. 609-646.

AWS Welding Handbook; Welding Processes. $8^{\text {th }}$ ed. Miame, 1991. v. 2, p. 955.

BABU, S.S. The mechanism of acicular ferrite in weld deposits. Current Opinion in Solid State \& Materials Science, v. 8, p.267-278, 2004.

BATISTA, G. Z. ; SOUZA, L. F. G. ; BOTT, I. S. ; RIOS, P. R. Effect of MA constituent on mechanical properties of a $\mathrm{Nb}-\mathrm{Cr} / \mathrm{Nb}-\mathrm{Cr}-\mathrm{Mo}$ API X80 Steel. In: INTERNATIONAL CONFERENCE ON THERMOMECHANICAL PROCESSING: MECHANICS, MICROSTRUCTURE AND CONTROL, SHEFFIELD. 2002. The University of Sheffield. p.240-244.

BATISTA, G. Z.; SOUZA, L. F. G.; BOTT, I. S.; RIOS, P. R. Estudo da correlação microestrutura propriedades mecânicas de aço da classe API X80. In: CONGRESSO DA ABM, 58., 2003 Rio de Janeiro.

BAYRAKTAR, E.; KAPLAN, D. Mechanical and metallurgical investigation of martensite-austenite constituents in simulated welding conditions. Journal of Materials Processing Technology, v. 153-154, pp. 87-92, 2004.

BHADESHIA, H. K. D. H.; HONEYCOMBE, R. Steels: Microstructure and properties. Editora: Elsevier, $3^{\text {a }}$ ed., p. 287-306, 2006. 
BIRNIE, J.V. An Introduction to Electron Beam Welding. Physics in Technology, p.116$122,1976$.

BOWKER, J. T.; ORR, R. F.; RUDDLE, G. E.; MITCHELL, P. S. The effects of vanadium on the parent plate and weldment properties of API 5L X80 linepipe steels. In: MECHANICAL WORK AND STEEL PROCESSING, 35, 199, Pittsburg. Proceedings, Pittsburg: Iron and Steel Society, 1993. p. 403-412.

BUZZICHELLI, G., ANELLI, E. Present Status and Perspectives of European Research in the Field of Advanced Structural Steels. ISIJ Internacional, v.42, n.12, p.1354-1363, 2002.

CALDEIRA, E. A. et al. Desenvolvimento de aços atendendo a norma API 5L, no laminador de tiras a quente da Companhia Siderúrgica de Tubarão (CST). CONGRESSO ANUAL DA ABM, 60. , 2005, Belo Horizonte.

CHEN, J. H. et al. Micro-fracture behavior induced by MA constituent (island martensite) in simulated welding heat affected zone of HT80 high strength low alloyed steel. Acta Metallurgica, v.32, n.10, p.1779-1788, 1984.

COSTA E SILVA, A.; MEI, PR. Aços e ligas especiais. São Paulo: Edgard Blucher, 2006.

CUDDY, L. J. The Effect of Microalloy Concentration on the Recrystallisation of Austenite during Hot Deformation. Thermomechanical Processing of Microalloyed Austenite, Warrendale, PA: TMS, 1982, p.129-140.

GRAY, M.J. A guide for Understanding \& Specifying Chemical Composition of HighStrength Linepipe Steels. In: CONGRESSO ANUAL DA ABM, 60. , 2007, Vitória. 
GRONG, O.; MATLOCK, D. K. Microstructural Development in Mild and Low-Alloy Steel Weld Metal. International Materials Reviews, v.31, p. 27 - 48, 1986.

FERRANTE, M. ; FARRAR, R.A. The role of oxygen rich inclusions in determining the microstructure of weld metal deposits. Journal of Materials Science, v.17, p. 3293, 1982.

FURUHARA, T.; MORITANI, T.; SAKAMOTO, K.; MAKI, T. Substructure and crystallography of degenerate pearlite in an $\mathrm{Fe}-\mathrm{C}$ binary alloy. Materials Science Forum, v. 539-543, p. 4832-4837, 2007.

GORNI, A. A. Cálculo da temperatura de não recristalização para aços microligados em função da interação entre a precipitação e recristalização da austenita. Revista Escola de Minas, v.52, $\mathrm{n}^{\circ} 1$, p. 21-25, 1999.

GUIMARÃES, V. A. Influência da Taxa de Resfriamento nas Propriedades Mecânicas e no Micromecanismo de Fratura de um Aço Microligado com Nióbio e Titânio. 1997. Tese (Doutorado) - Faculdade de Engenharia Mecânica, Universidade Estadual de Campinas, Campinas. p. 157.

HERSHCOVITH, A. Non-vacuum electron beam welding through a plasma window. Nuclear Instruments and Methods in Physics Research, v. 241, p. 854-857, 2005.

HILLENBRAND, H. G., KALWA, C. High strength line pipe for project cost reduction. World Pipelines, v.2, n.1, 2002.

HILLENBRAND, H. G., GRAF, M., KALWA, C. Development and production of high strength pipeline steels. In: NIOBIUM 2001, Dec. 02-05, Orlando, Flórida, Proceedings Orlando, Florida, 2001. p.1-28. 
HILLENBRAND. H. G. et.al. Development of grade X120 pipe material for high pressure gas transportation lines. In: INTERNATIONAL CONFERENCE ON PIPELINE TECHNOLOGY, 4. , 2004, Ostend. Proceedings Ostend, Belgium, 2004.

HILLENBRAND, H. G.; LIESSEM, A.; BIERMANN, K.; HECKMANN, C. J.; SCHWINN, V. Development of high strength material and pipe production technology for grade X120 line pipe. In: INTERNATIONAL PIPELINE CONFERENCE IPC 2004, Calgary, Canadá. Proceedings Calgary, Canadá, 2004.

HONEYCOMBE, R. W. K. Aços: microestrutura e propriedades. Lisboa: Fundação Calouste Gulbenkian, 1982.

HULKA, K.; HEISTERKAMP, F. Weldability consideration in the development of structural steels. In: INTERNATIONAL CONFERENCE ON HSLA STEELS, 3. , 1995, Beijing. Proceedings Beijing: The Chinese Society for Metals, 1995. p. 543-551

IMLAU, K. P.; HELLERT, T. New steel solution for the worldwide car. Steel Research International, v.78, n. 3, p.180-184, 2007.

IPEA - Instituto de Pesquisa Econômica Aplicada. O Potencial de novas reservas e a lei do petróleo: é preciso alterar o regime de concessões? Disponível em: http://www.ipea.gov.br/sites/000/2/pdf/4a_Jornada_apresentacao_AdrianoPires.pdf. Acesso em setembro de 2009.

KRAUSS, G.; THOMPSON, W. Ferritic microstructures in continuously cooled low-and ultralow-carbon steel. ISIJ Internacional, v.35, n.8, p.937-945, 1995. 
KOGA, S.; INUZUKA, M.; NAGATANI, H.; IWASE, T.; MASUDA, H.; USHIO, M. Study of all position electron beam welding process for pipeline joints. Science and Technology of Welding \& Joining, v.5, p. 105-112, 2000.

KOU, S. Welding Metallurgy. New York: John Wiley \& Sons, 2003. 461 p.

KORCHYNSKY, M. Use of vanadium in flat products (place and strip). In: VANITEC SEMINAR ON VANADIUM STEELS GUILIN, NOVEMBER 6-7, 2000. Proceedings. London, UK: Vanitec, 2000. V. 101, p. 42-47 Disponível em: http://vanitec.org/wpcontent/uploads/2011/09/Use-of-Vanadium-in-Flat-Products-Plate-and-Strip.pdf. Acesso em 25 abr. de 2013

MARTIN, R. V.; LANDGRAF, F. JG. ; GOLDENSTEIN, H.; RAMIREZ, M. G.; RODRIGUES, A. C. P.; GORNI, A. A. Caracterização Magnética do Aço X80 para Gasoduto. In: RIO PIPELINE CONFERENCE \& EXPOSITION. 2007, Rio de Janeiro.

MODENESI, P. J; MARQUES, P. V. Apostila: Introdução aos Processos de Soldagem. Belo Horizonte: Universidade Federal de Minas Gerais - Departamento de Engenharia Metalúrgica, 2000, p.22-24. Apostila.

OGATA, P. Caracterização microestrutural de chapa laminada de aço API X65 após austenitização e resfriamento. 2009. Dissertação (Mestrado) - Escola PolitécnicaUniversidade de São Paulo, 2009. p. 122.

PINTO, F.C. Caracterização mecânica e microestrutural do aço API 5L - X65 soldado por feixe de elétrons. 2011. Dissertação (Mestrado) - Escola de Engenharia de Lorena, EEL-USP, 2011. p. 121 
PLAUT, R. L. ; GORNI, A. A.; NAKASHIMA, J. T. ; PEREIRA, M. M. ; SILVEIRA, J.

D. Estudo das propriedades mecânicas do aço API X70 produzido por laminação controlada. Tecnologia em Metalurgia, Materiais e Mineração, v. 6, n. 1, p. 7-12, 2009.

RÄSÄNEM, E.; TENKULA, J. Phases Changes in the Welded Joints of Construction Steels. Scandinavian Journal of Metallurgy, v.1 , p. 75-80, 1982.

RYKALINE, N. N. Les sources d'energie utilisées en soudage. Soudage et Techniques Connexes, v.28 n. 11/12, p. 471-478, 1974.

SÁ, M. A. F. Estudo da soldagem por feixe de elétrons de aços inoxidáveis austeníticos utilizados na fabricação de bocais superiores e inferiores de elementos combustíveis. 2005. Dissertação (Mestrado) - Escola de Engenharia de Lorena - USP, Lorena 2005. p.101.

SANDERSON, A., PUNSHON, C.S., RUSSELL, J.D. Advanced welding processes for fusion reactor fabrication. Fusion Engineering and Design, v. 49-50, p. 77-87, 2000.

SANT'ANNA, P. C. Influência de tratamentos térmicos intercríticos na microestrutura e propriedades mecânicas do aço API 5L X65. 2006. Tese (Doutorado) - Faculdade de Engenharia Mecânica - Universidade Estadual de Campinas. Campinas, 2006. p. 148 .

SCHILLER, S.; HEISIG, U.; PANZER, S. Electron Beam Technology. New York: John Wiley \& Sons, 1982. p. 508.

STRANGWOOD, M.; BHADESHIA, H. K. D. H. In: CONFERENCE TRENDS IN WELDING RESEARCH, 1986. Gatlinburgh, TN. Proceedings Gatlinburgh: ASM, 1986. 
SHUI, C.K., REYNOLDS, W.T., SHIFLET, G.J., E AARONSON, H.I. A comparison of etchants for quantitative metallography of bainite and martensite microstructures in $\mathrm{Fe}-\mathrm{C}$ Mo alloys. Metallography v. 21, p. 91-102, 1988.

TANIGUCHI, C. Princípios de engenharia de Soldagem. São Paulo: EPUSP, 1976.

SUN, Z.; KARPPI, R. The application of electron beam welding for the joining of dissimilar metals: an overview. Journal of Materials Processing Technology, v. 59, p. 257-267, 1996.

TERADA, Y.; KIYOSE, A. ; DOI, N.; MORIMOTO, H. ; KOJIMA, A. ; NAKASHIMA, T.; HARA, T. ; SUGIYAMA, M. High-Strength Linepipes with excelente HAZ toughness. Nippon Steel Technical Report, v.90, p. 88-93, 2004.

VANDER VOORT, G. F. Metallography: Principles and Pratice. New York: McGrawHill, 1984. p.427.

WAINER, E.; BRANDI, S. D.; MELLO, F. D. H. Soldagem: processos e metalurgia, São Paulo: Editora Blucher, 1992.

YANG, J. R. ; BHADESHIA, H. K. D. H. In: CONF TRENDS IN WELDING RESEARCH, 1986, Gatlinburgh, TN, ASM, 1986. Proceedings Gatlinburgh, TN: ASM, 1986. ref.12

YOUNG, M.K.; HAKCHEOL, L.; NACK, J. L. Transformation behavior and microstructural characteristics of acicular ferrite in linepipe steels. Materials Science Engineering A 478, p. 361-370, 2008. 
ZAJAC, S.; SCHWINN, V.; TACKE, K.H. Characterization and quantification of complex bainitic microstructures in high and ultra-high strength linepipe steels. Materials Science Forum, v. 500-501, p. 387-394, 2005.

ZHAO, M. ; YANG, K. ; XIAO, F. ; SHAN, Y. Continuous cooling transformation of undeformed and deformed low carbon pipeline steels. Materials Science and Engineering A, v. 355, p.126-136, 2003. 